Portland State University

PDXScholar

$1-1-1986$

\title{
An econometric study of an oil-exporting country: the case of Iran
}

Abbas Heiat

Portland State University

Follow this and additional works at: https://pdxscholar.library.pdx.edu/open_access_etds Let us know how access to this document benefits you.

\section{Recommended Citation}

Heiat, Abbas, "An econometric study of an oil-exporting country: the case of Iran" (1986). Dissertations and Theses. Paper 564.

https://doi.org/10.15760/etd.564

This Dissertation is brought to you for free and open access. It has been accepted for inclusion in Dissertations and Theses by an authorized administrator of PDXScholar. Please contact us if we can make this document more accessible: pdxscholar@pdx.edu. 
AN ECONOMETRIC STUDY OF AN OIL-EXPORTING COUNTRY:

THE CASE OF IRAN

by

ABBAS HEIAY

A dissertation suomitted in partial fulfillment of the requirements for the degree of

\author{
DOCTOR OF PHILOSOPHY \\ in \\ SYSTEMS SCIENCE
}

Portland State University

1986 
TO THE OFEICE OF GRADUATE STUDIES AND RESEARCH:

The members of the Committee aporove the dissertation of Abbas Heiat presented August 16, 1986.
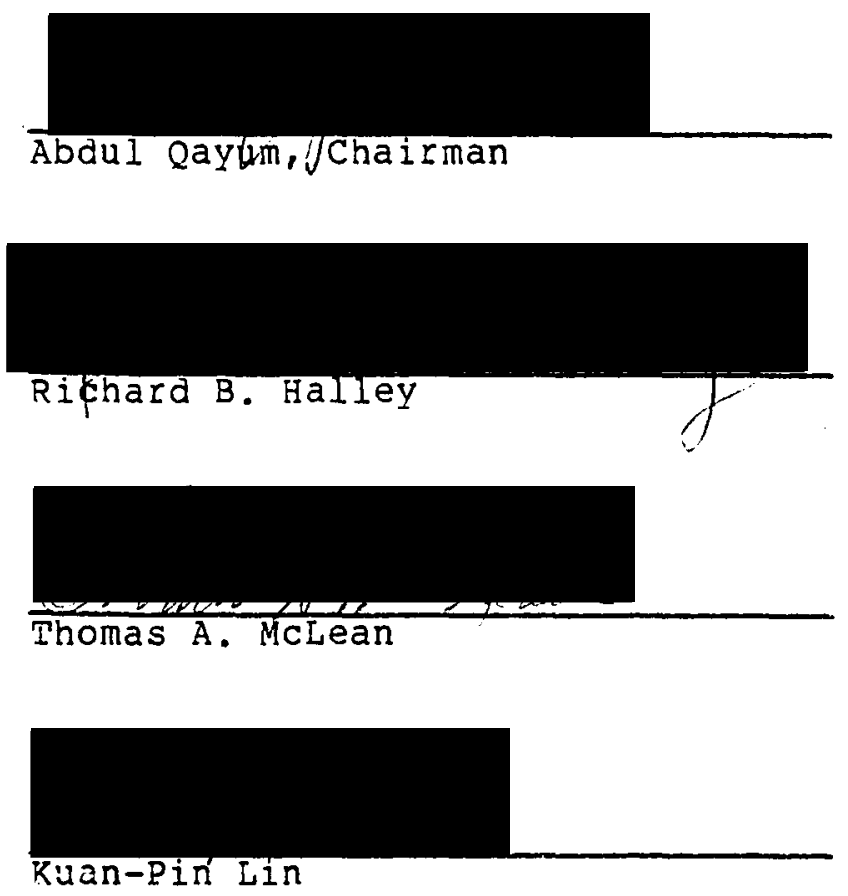

APPROVED :
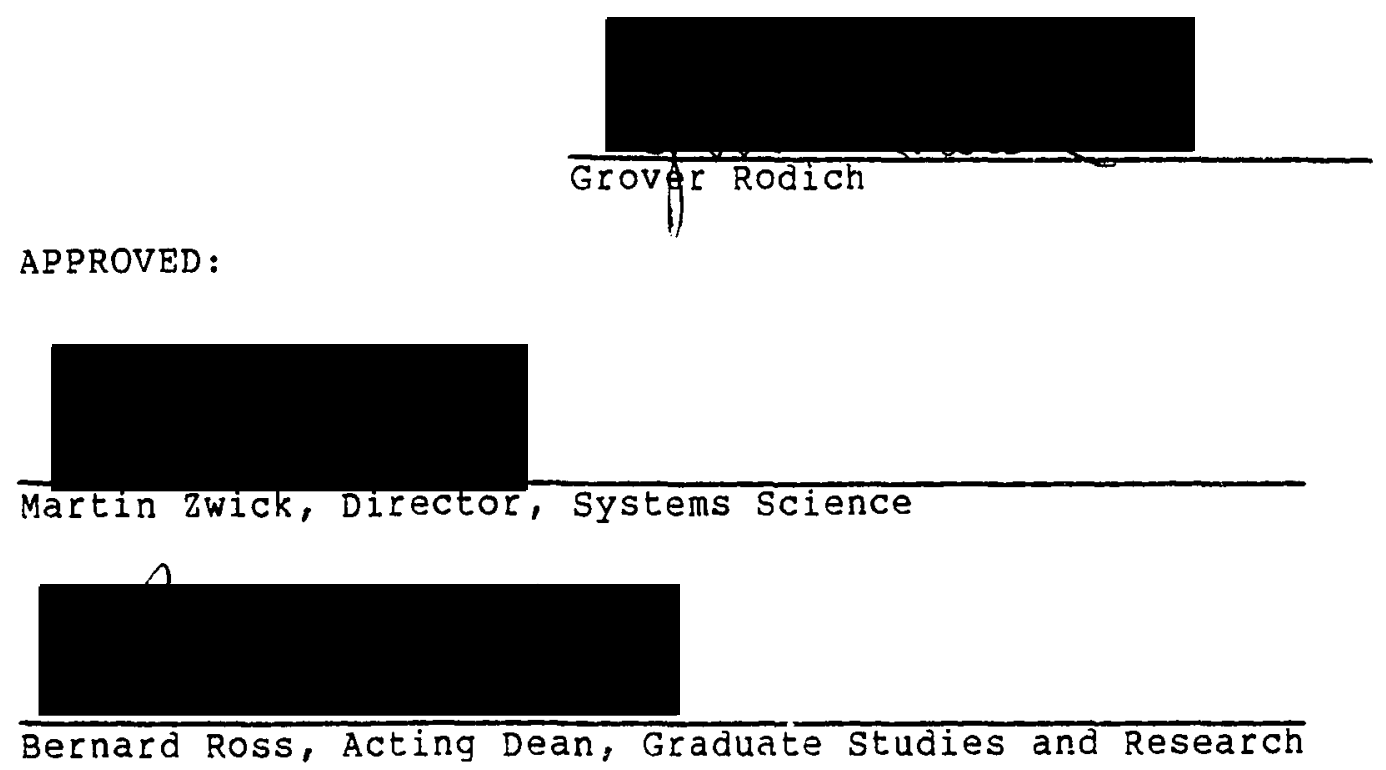
AN ABSTRACT OF THE DISSERTATION OF Abbas Heiat for the Doctor of Philosophy in Systems science presented August 16,1986

Title: An Econometric Study of an Oil-Exporting Country: The Case of Iran

APPROVED BY MEMBERS OF THE DISSERTATION COMMITTEE:
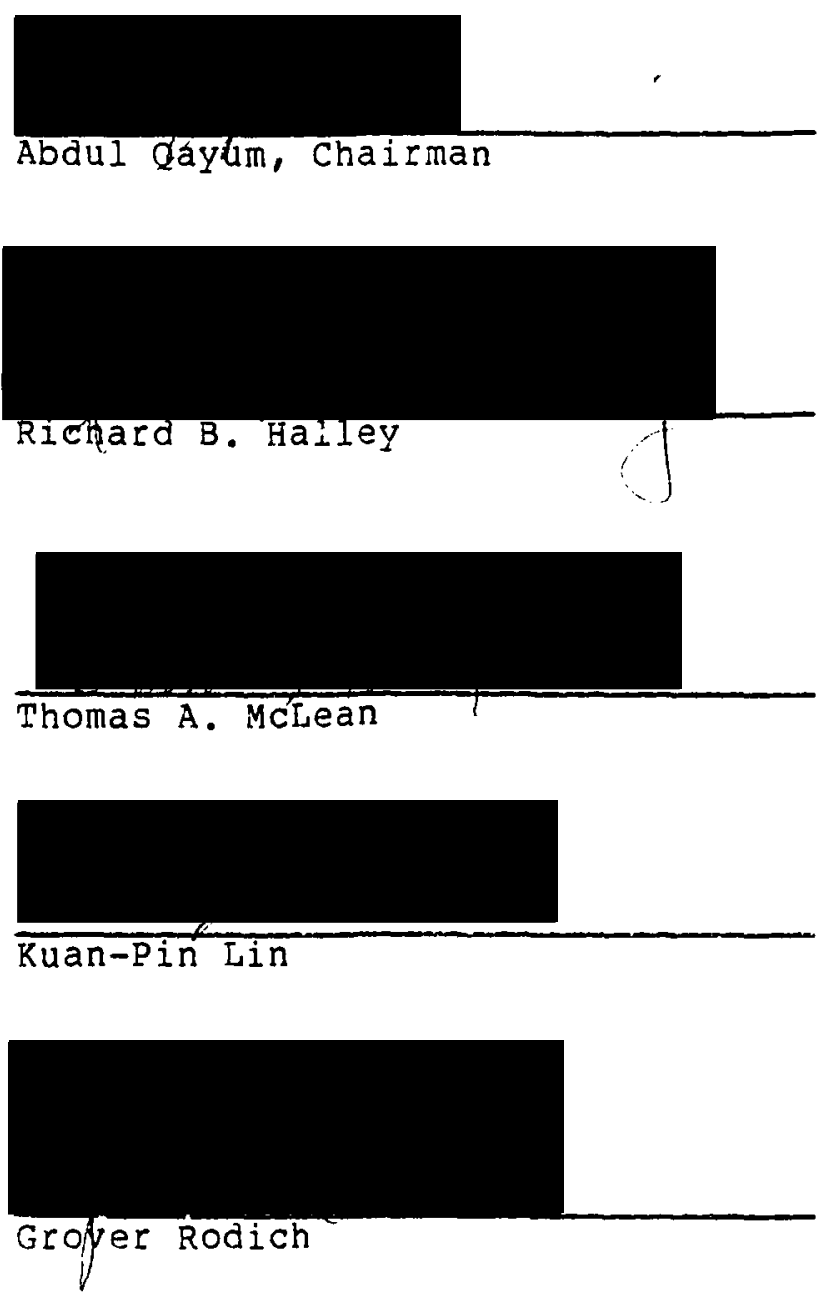
The main objective of this study is to contribute toward an analytical and empirical work on the oil-based developing economy of Iran. It focuses on the aggregate behavior of the Iranian economy through a simple linear econometric model.

After a survey of the literature on the theoretical framework of macroeconomic models for the developing countries in general, and for the oil exporting developing countries in particular, a linear econometric model for the Iranian economy is formulated and its logical and economical aspects are exp-ained. The proposed model consists of basic consumption, pruduction, foreign trade, and employment relationships.

Estimation of the behavioral equations are carried out by Ordinary Least Square and Two Stage Least Square estimators. The model is estimated over the period of 1959-76. Data published by the Plan and Budget Organization of Iran in the 1978 edition of the "Economic Trends of Iran" are used for the estimation of the parameters of the model. Historical simulation of the model has been performed to test the validity and the fitness of the model as a whole. The results obtained from the estimation of the consumption functions seem to indicate that the aggregate Iranian consumption behavior can be best explained by Friedman's Permanent Income Hypothesis. An attempt has been made to estimate the aggregate production function of 
the urban sector according to various Cobb-Douglas production functions and linear production function with constant returns to scale. All of these specifications gave implausible results.

In general, the results of this study demonstrate that the links between different sectors of the Iranian economy are very weak and the import substitution strategy of the government during the period of study failed to establish a genuine domestic industrial base and to reduce its dependence on foreign resources. 


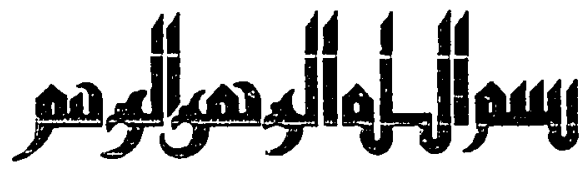

In the Name of God - Most Mejciful, Most Compassionate

\author{
ACKNOWLEDGMENTS
}

The responsibility for material presented in this dissertation rests with the author. But, intellectually I owe so much to so many that it is impossible to acknowleage them individually.

My first introduction into the application of regression analysis to the economic studies came as a result of taking econometric and economic planning courses taught by Dr. Abdul Qayum. His remarks and discussions on the many related issues were lucid and thought provoking. Later as my advisor and dissertation committee chairman I profited enormously from his suggestions and guidance on the subject matter in the course of preparation of this study. For all this I remain deeply grateful.

I wish also to express my profound gratitude to the other members of my dissertation committee, Dr. Halley, Dr. McLean, Dr. Lin and the Graduate Office Representative, Dr. Rodich for their support, guidance, constructive critical 
remarks, objectivity in approach, open-mindedness, and for sharing their vast inteliectual capacity.

I would also iike to express my gratitude to the Mostazafan Foundation of New York for giving me financial aid towards part of my dissertation research. My special thanks are due to Mrs. Mary Dozark for her sympathy and efficient typing of the first and final draft of this aissertation. 
TABLE OF CONTENTS

PAGE

ACKNOWLEDGMENTS....................... ii

LIST OF TABLES...................... viii

LIST OF FIGURES....................... $\mathrm{x}$

CHAPTER

I INTRODUCTION..................... 1

Purpose..................... 4

The Model and its Structure.......... 6

Research Methodology............... 7

Progress and Plans of the Study........ 8

NOTES............................ 10

II ECONOMIC MODELS FOR DEVELOPING COUNTRIES:

A THEORETICAL FRAMEWORK.............. 11

The Keynesian Model............... 12

Growth Models................... 15

Balanced vs. Unbalanced Growth........ 18

Dualistic Models................. 20

The Oil-Exporting Dual Economy........ 23

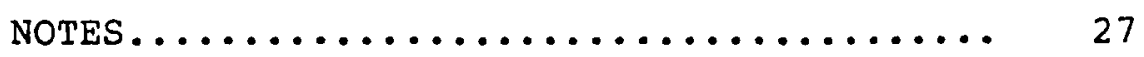

II I MACROECONOMETRIC MODELS OF DEVELOPING

COUNTRIES WITH SPECIAL REFERENCE TO MODELS

OF IRAN....................... 30 
Surrvey of Models for Iran........... 30

Desired Characteristics of a Macroeconometric Model For an Oil-Exporting

Dual Economy.................. 33

NOTES....................... 46

IV STRÜCTURAI CHARACTERISTICS OF THE

IRANLAN ECONOHY ................. 47

Characteristics of the Economy........ 48

Specification of the Model.......... 51

Consumption Expenditures

Foreign Trade Relations

Production Functions

Employment

List of Variables................ 54

Endogenous Variables

Predetermined Variables

Lagged Endogenous

Consumption Expenditures............ 55

Foreign Trade Relations............. 62

Production Functions............... 54

Employment................... 66

Indirect Taxes................. 66

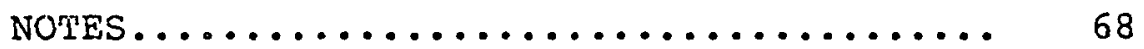

V ESTIMATION AND EVALUATION OF THE MODEL..... 70

Basic Aspects of Data Limitation....... 70

Estimation Procedures.............. 73

Private Consumption Equations......... 75

Short-run and Long-run Marginal

Propensity to Consume............ 79

Government Consumption Expenditures.... 81 
Foreign Trade Relations........... 81

Production Equations.............. 83

Employment and Indj.rect Taxes........ 36

Historical Similation of the Model..... 88

The Reduced Form of the Model........ 107

NOTES......................... 114

VI CONCLUSIONS AND RECOMMENDATIONS......... 116

Summary................... 117

Conclusions...................... 119

Recommendations................. 122

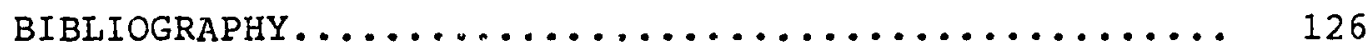

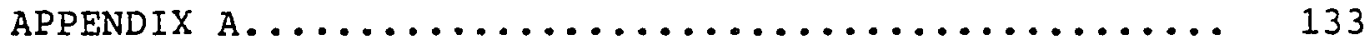

APPENDIX 
I Summary of Main Characteristics of the UNCTAD, 1968 Model for Iran.......... 38

II Summary of Main Characteristics of the VAKIL, 1974 Model for Iran........... 40 II Summary of Main Characteristics of the SHANSHAHNI, 1976 Model for Iran........ 42 IV Summary of Main Characteristics of the HEIAT, 1986 Model for Iran............ 44

$V$ Results of Historical Simulation of the Model...................... 91

VI The Model and its Estimated Structural

Equations..................... 92

VII Reduced Form Equations................ 108

VII Dynamic Multipliers for Value Added in Urban sector.....................110

IX Dynamic Multipliers for Value Added in urban sector. $\quad \ldots \ldots \ldots \ldots \ldots \ldots \ldots \ldots$

K Dynamic Multiplie ${ }_{\perp}$ or Urban Consumption... 111

XI Dynamic Multipliers for Rural Consumption... 111

XI Dynamic Multipliers for Government 
XI I I

Dynamic Multipliers for IMC. Policy

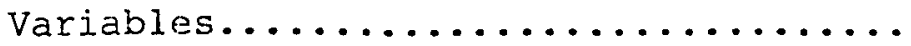

XIV Dynamic Multipliers for LU. Policy

Variable; INVU1..................

113 
LIST OF FIGURES

$\begin{array}{ll}\text { FIGURE } & \text { PAGE }\end{array}$

1. Historical Simulation of Value-Added in Agriculture................... 95

2. Historical Simulation of Value-Added in

Urban sector.................... 96

3. Historical Simulation of Private

Consumption in Agriculture

sector...................... 97

4. Historical Simulation of Private

Consumption in Urban Sector........... 98

5. Historical Simulation of Government

Consumption Expenditures............ 99

6. Historical Simulation of I mports of

Consumer Goods.................... 100

7. Historical Simulation of Imports of

Capital Goods and Intermediate

Goods....................... 101

8. Historical Simulation of Non-Oil Exports.... 102

9. Historical Simulation of Labor Employed

in Agriculture................ 103

10. Historical Simulation of Labor Employed

in Urban Sector.................. 104 
11. Historical Simulation of Value-Added in

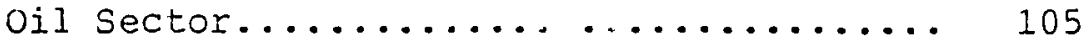

12. Historical Simulation of Net Indirect

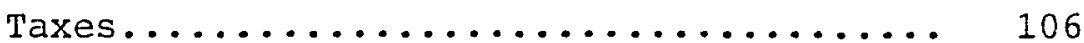


CHAPTER I

INTRODUCTION

Since the end of World war II the oil sector has been playing a very significant role in the economic and social development of oil exporting developing countries. Quadrupling of oil prices in the $1970^{\prime} \mathrm{s}$ and the ensuing oil euphoria gave the impression that the oil exporting developing countries were in a short-cut to the economic prosperity and industrial advancement. Oil revenues have proved, however, to be much more than a costless source of financing development projects in the oil-based developing nations.

The role natural resources play in economic development is indeed very difficult to determine. However, countries richly endowed with resources appear to have some initial advantage in achieving economic growth over other developing countries that are less fortunate. This does not necessarily imply that natural resources per se provide the only prerequisites for economic development. The internalization of the growth process and a genuine economic development requires, among other things, a strong national commitment and a dedicated leadership with broad-based 
popular support, technical knowleage, and skill as well as organizational ability in resource alloration.

Essentially, we can characterize an oil exporting developing economy by an enclave modern oil sector, a growing industrial urban sector, and a stagnating agriculture sector. The most significant feature of the oil sector is its almost complete independence from the rest of the economy. Little contribution is being made by domestic sectors to the production of cruce oil. In narticular, the participation of domestic labor force in the oil sector is negligible. Oil income, however, makes up a large share of national income, and almost the whole of foreign exchange receipts. Furthermore, oil sector generates sufficient savings and foreign exchanges to compensate for inadequate j.nternal savings and export earnings. In contrast to the classical dualistic models suggested by Lewis, Fei-Ranis and Jorgensan, in an oil-based developing economy financial resources flow from the oil sector to the rest of the economy, rather than from agriculture sector to the other indigenous sectors. Furthermore, surplus resource in an oil exporting country in contrast to labor surplus economy is exhaustiole and the supply of trained labor force and skilled managers is very limited.

The analysis of sectoral interdependencies as an approach to the study of economic development has long occupied the attantion of economists. However, the 
relationship between indigenous sectors of a developing country and its revenue generating enclave sector has seldom been subjected to the kind of analytical vigor that has characterized the more conventional cases of intersectoral relationships, where export oriented enclaves have been nonexistent. 1

In this study an attempt has been made to fill the foregoing vacuum in the literature by providing a theoretical framework within which the growth dynamism of an oilbased developing economy could be systematically analyzed. The experience of Iran during 1959-1978 presents a classic case for the study of economic growth of an oil exporting developing economy. Iran is better placed than most other developing countries to carry out a successful industrialization policy and avoid its negative side effects. She has an extraordinary range of natural resources which make ner independent of foreign supplies of critical materials. The variety of climate and of soils make Iran potentially self-sufficient in food-stuffs and agricultural raw materials. Nevertheless, after almost three decades of development planning in the wake of the Islamic kevolution, Iran's industrial base remained fragile and the country had lost its earlier self-sufficiency in agriculture. 


\section{Purpose}

The main objective of this study is to contribute toward an analytical and empirical work on the economy of Iran.

The disillusioning experience of four development decades has demonstrated the weakness of simplistic approaches to the highly compiex phenomenon of economic development. It is now a widely accepted notion that a standard model of development is not likely to work for all developing countries. 2 The past history of these countries with respect to economic performance has been quite diverse. Mush of this diversity is through resource endowments. Social and cultural differences have also contributed a great der. to the diversity of economic performance among developing countries. It is not surprising, therefore, that the development economics has so far failed to yield a convincing fundamental and coherent analysis or theory of development.

An increasing number of economists and planners are becoming sceptical about the whole approach of contemporary development economics. There are others who argue that the generalizations of economic theory are based on the particular circumstances of the advanced countries and are, therefore not universally valid. Finally, there are critics who are questioning the relevance of economic 
theory and basic tools of economic theory to the developing countries. 3

We agree with H. Myint that

There can be no serious quarrel with those critics who stress the need to increase the realism of economic theory by taking into account the various social, historical, and institutional differences between the advanced and underdeveloped countries. If anything our analysis has suggested the need also to take into account the differences between the underdeveloped countries themselves with respect to the degree of population pressure, the over-all size of the eccnomy, ...4

The argument of those economists who question the relevance of conventional economic theory is more debatable. We believe that the body of knowledge and tools developed and structured in the form of economic theory is important and useful. The acceptance or rejection of the relevance of conventional economic theories to the developing economies should be based on the results of the empirical studies rather than conjecture. Indeed, our proposed research has two specific main objectives. The first objective is to apply the conventional consumption, production and foreign trade theories to the Iranian data and report the findings. The second objective is concerned with the construction of an econometric model for the Iranian economy and testing its relevance and power in explaining the macroeconomic behavior of an oil-based developing country. 
The Model and Its Structure

The study presented here is the result of an effort to increase our knowledge of the structure cf the oil-based Iranian economy. This constitutes a linear econometric model, plus its theoretical and policy implications for Iran. It focuses on the behavior of the economy in an aggregate fashion. The proposed econometric model consists of twelve stochastic equations with five identities. There are thirty-two variables in all, fifteen of which are predetermined, consisting of seven lagged endogenous variables and eight exogenous variables.

Several interesting hypotheses for the Iranian economy are suggested within the structure of the model. Indeed, the twice dualistic nature of the economy is reflected in the consumption, supply, foreign trade and employment equations. There is, on the one hand, the conventional dualism which distinguishes between traditional agriculture and industrial sectors, and on the other hand, the private sector and public sector duality reflecting the importance of the oil exports. There are, however, concerns which are not adequately treated. Considerable compromises have been made between constructing an ideal model of an oil-exporting dualistic economy and the available data. These compromises have been most significant with respect to institutional factors, infrastructure, capital stock and 
underutilized production capacity, income distribution and rural-urban migration.

Two main limitations of the model are: the linearity of the behavioral equations and the highly aggregative character of the variables used in it.

Research Methodology

The estimation of behavioral equations are estimated by ordinary least square and two stage least square estimators. To overcome the problem of autocorrelation and to obtain efficient estimates first order serial correlation (ARI) procedure proposed by Beach and McKinon are used to estimate equations whose disturbances display first order serial correlation. Variables are measured in 1959 constant prices in billion rials and in thousands of persons. Giver a model whose parameters have been estimated, given initial values for the endogenous variables, and given time series for the exogenous variables, the model can be solved over some range of time to yield solutions for each of the endogenous variables. In a historical simulation, actual values in the base year are given as initial condition for the endogenous variables. Actual time series beginning in the base year and ending in the last year of the observation are used for the exogenous variables. Values for the endogenous variables after the base year are determined by the simulation solution. A comparison of the 
original data with the simulated series for each endogenous variable then can provide a useful test of the validity of the model. In this study the historical simulation of the model has been performed to evaluate the fitness of the model as a whole and to see whether equations will reproduce the results which are close to the historical data.

\section{Progress and Plans of the Study}

This study is primarily concerned with a quantitative analysis of the economy of Iran. The method of study can be described as a quantitative economic research in which the tools of economic theory and statistical inference are applied to the study of the Iranian economy during the 1959-1976 period for which data have been collected.

Therefore, first a critical survey of the literature on the theoretical framework of macroeconomic model building for less developed countries in general and for oil-exporting developing countries in particular is made in Chapter II. Then a theoretical framework of macroeconometric models for developing oil-exporting is outlined in Chapter III. In this chapter two-gap and Harrod-Domar approaches to model building in development economies are considered. Special reference is made to the oil-based economy of Iran.

In Chapter IV, after drawing a brief sketch of the structural characteristics of the Iranian economy, an 
econometric model is formulated and its economic and logical aspects are explained. The model consists of basic consuintion expenditure relationships, production, foreign trade, and employment sectors.

Estimated structural equations are presented in

Chapter $V$. To study the dynamic behavior of the model, structural equations are transformed into the reduced form where each current endogenous variable is solely defined in terms of predetermined variables. Given the reduced form of the model, the fluctuations of the major endogenous variables over time are then explored. 
NOTES

${ }^{1}$ A. M. Fekrat, "Growth of OPEC-Type Economies: A Preliminary Theoretical Inquiry". Economica Internationale, February 1979.

${ }^{2}$ M. P. Todaro, Economic Development in the Third World. New York: Longman Inc., 1981, pp. 12-16.

$3 \mathrm{H}$. Myint, Economic Theory and the Underdeveloped Countries. New York: Oxford University Press, 1967, pp. 3-26.

${ }^{4} \mathrm{H}$. Myint, p. 15 . 
ECONOMIC MODELS FOR DEVELOPING COUNTRIES:

A THEORETICAL FRAMEWORK

Construction of macroeconometric models for developing countries has become an increasingly popular endeavor in the last few decades. Both national planning organizations and international agencies like the United Nations Committee on Trade and Development (UNCTAD), Economic Commission for Latin America (ECLA), Economic Commission for Asia and the Pacific (ESCAP), International Monetary Fund (IMF), and World Bank are interested in quantitative analysis of aggregate economic relationships for the furpose of forecasting as well as policy prescriptions.

Clearly, the less developed countries might draw on some of the relationships used in models for economically advanced industrialized economies, but the problems faced by such economies are of a different nature. Therefore, the structure of equations and definitions of variables should explain very different local institutions and behavioral characteristics. 1 While there have been numerous attempts to build such models, it will be some time before truly satisfactory models can be developed. In the absence of a general theoretical framework within which the problems of the developing countries can be studied, much 
of the debate has taken place in a theoretical vacuum. Moreover, lack of adequate data has served as an additional obstacle in developing and in estimating satisfactory models. In spite of these limitations, it can be argued that the construction and estimation of econometric models for developing countries may be of substantial interest and necessity. Econometric models, by tracing the historical records of major economic variables, provide useful information about the general behavior of the developing economies in a systematic and highly organized fashion. In this chapter we are going to take a brief look at some of the economic theories and their application to the developing economies and submit some simple thoughts on macroeconomic model building for less developed countries in general and for oil-exporting developing economies in particular.

\section{The Keynesian Model}

The Keynes contribution to economic theory, which restored macroeconomic to its ciassical leading role, paved the way for constructing econometric models based on the Keynesian Theory of effective demand and income determination. Keynes' central argument was that the employment is governed by the level of national output, and that in turn is controlled by the volume of demand for consumers' goods, private investment and public expenditure. The proportion 
of income that is not consumed constitutes savings; the proportion of output that is not consumed constitutes investment. But desired savings by consumers and desired investment or planned investment by producers can only coincidently be in balance, because they are determined by quite unrelated considerations. Savings depend on the marginal propensity to consume, that is on how much people wish to spend of each additional dollar received. The willingness to invest, on the other hand, depends on the return on investment as well as the cost of borrowing money, i.e., the rate of interest. Given that marginal propensity to consume is relatively stable, the most variable element in the system is desired investment. It is the manner in which savings and investment are brought into balance that is the core of Keynes' theoretical system. If there is a shortfall in investment, the national income is reduced through multiplier process until a new equilibrium state is reached. In the process savings are reduced and are brought into balance with desired investment. But there is no reason at all why the equilibrium should be at a level of full employment. It can correspond with any level of employment. The same process operates in reverse if desired investment exceeds desired savings. Keynes' major contribution was to demonstrate that the economy might not self-adjust as classical economists believed it does. The principal implication of the Keynesian 
message is that public policy must be used to alter the rate of aggregate demand.

The Keynesian system has certain limitations. In the last two decades it has not not been able to help governments deal with the problem of stag-flation, a combination of inflation with high unemployment. But more serious limitations arise when the logic is applied to developing economies. In developing countries the problems of poverty and unemployment cannot be solved by Keynesian policies, since it is not effective demand that is lacking but the infrastructure and resources on the supply side. If there is insufficient productive capacity to meet increased demand, a rise in income will stimulate inflation more than consumption. Where incomes are very unequally distributed, an increase in investment will not necessarily generate savings of the form and quantity desired. Where the necessary structure of an integrated economy and financial system does not exist, Keynesian theoretical system cannot be applied without substantial adjustments. The "general theory" is in fact specific to the time and place of its formulation, i.e., a period of persistent under-utilization of resources in the economically advanced countries. But the case for government intervention is more general and the value of economic management has been demonstrated in practice. 


\section{Growth Models}

It was not long before attempts were made to translate Keynesian equilibrium theory into a theory of growth, and to find in it prescriptions for economic development in the developing economies. If the fundamental engine of increasing employment, national output, and income is investment, then the net growth is a necessary accompaniment of progressive capitalization of pruaucioñ through time. The model proposed by R. F. Harrod and $\mathbf{E}$. Domar was an early mathematical attempt to show that growth is directly related to savings and indirectly related to the capital/output ratio. The model has two basic assumptions. It assumes that there is a fixed ratio between a unit of capital injected into the system and the resulting value of output produced in a year. It further assumes that the level of savings is also a fixed proportion of income. 2 Given these assumptions, an investment made at time $t$ will generate additional income through capital/output ratio and the multiplier (reciprocal of the marginal propensity to savel at time $t+1$ and the resultant increased savings from the larger income will be invested to generate further growth at time $t+2$ and so on. However, an initial error in the right level of investment is also enlarged through the multiplier. So the expected level of demand at $t+1$ on which investment decisions at $t$ are based, may differ substantially from the 
actual growth of demand. The neoclassical economists, however, tried to cope with this problem by additions and refinements of the Harrod-Domar model.

The neoclassical model begins with an aggregate production function that includes technical progress:

$$
\begin{aligned}
& Y=f(A, K, I) \text { where } \\
& Y=\text { national output } \\
& A=\text { technical change factor } \\
& K=\text { capital stock } \\
& I=\text { labor }
\end{aligned}
$$

Technical progress is usually assumed to be neutral, allowing for increased productivity of both labor and capital and leaving the rate of substitutions between them unaffected. Moreover, like the Harrod-Domar model, the simple neoclassical model assumes a constant returns to scale, so that an equal increase in the amount of labor and capital used in the production process would result in the increase of output by the same proportion. 3 While the neoclassical model may seem to contain more realism, additional assumptions like perfect competition in all markets reduce its applicability. There has been, however, important spin-off from this thinking, in such areas as the contribution of capital, labor and technological change to economic growth. The importance of savings was specially emphasized, and since developing countries are unable to raise enough savings to finance sufficiently high growth 
rates, the international development assistance was recommended as an important suostitution.

To achieve economic growth, developing countries must choose a strategy for growth. Neoclassical growth theories started from a base of an already dynamic and developed economy, but they did not have much to say about an underdeveloped country seeking to initiate growth mainly from its own resources. Among other problems, this was one question to which economists turned their attention.

Kindelberger saw the small size of the market as one of the major causes of underdevelopment and suggested that large sums of capital are needed to build up the infrastructure before economic development can take place. 4 Investment in roads, ports, transportation as well as dams, electricity and communication networks ties countries together and creates large markets which allow economies of scale and greater specialization in the production process. Lack of adequate funds, however may frustrate the development of the desired infrastructure. In the absence of lump-sum capital, exports can also increase the size of the domestic market. According to classical theory increased export demand, or "vent for surplus," results in the utilization of otherwise idle resources, permits greater specialization and leads to increased productivity. However, as Hla Myint points out, increased demand for exports in many less developed countries has led to growth but not development. 
Specialization in export production in most cases merely involves the expansion of old techniques to new areas and no qualitative change in production takes place. Furthermore, specialization frequently hurts local producers. When demand in international market falls off, they have nothing to fall back on and end up in debt to foreigners or the domestic money lenders. 5

Balanced vs. Unbalanced Growth

Growth strategies proposed in the 1950 s can be classified into two broad categories: "balanced" and "unbalanced".

Proponents of the balanced growth strategy advocate a comprehensive simultaneous investment in all sectors. Ragnar Nurkse was among those who argued for spreading investment across the economy and enlarging the size and volume of the market. He was also concerned with the prublem of generating savings and had some doubts about the value of external aid. He emphasized very strongly the role of state in controlling trade movements, enforcing savings through taxation. He points out that a country importing capital goods rather than consumption goods is saving insofar as some of the domestic income is not used for consumption. But to translate such savings into domestic savings is another matter, for it is likely that the unsatisfied demand for foreign goods will be in part transferred 
to consumption of goods produced domestically. 6

Rosenstein-Rodon, another chief proponent of balanced growth, states that a big-push policy is necessary to increase income and demand. Coordination of investment provides externalities inasmuch as new industries increase the demand for each other's products and lower the cost of their inputs. Integration of investment also facilitates the training of a larger pool of labor from which all industries benefit. 7 The arguments put forward by balanced growth theorists seem plausible but nonetheless rest on assumptions that are unlikely to be fulfilled in developing countries. They assume highly elastic supplies of factors of production. But we know that capital is generally in low supply if not totally scarce in most developing countries. Unskilled labor is abundant in supply, but developing countries suffer enormously from scarcity of skilled workers, technicians and managers. Thus any "big-push" program puts a tremendous strain on such resources. Eurthermore, the scarcity of entrepreneurs and the imperfections in the market require government intervention at least as a corrective measure and coordinator. The critics of balanced growth strategy maintain that if a councry had the resources to launch massive investment programs, it would not be underdeveloped in the first place. Scistovsky and Hirschman advocate a selective approach to development. It does not in any way imply the development of one sector of 
the economy to the apparent neglect of other sectors. The interdependence among various sectors is not ignored. What is argued here is simply concentration of scarce capital and manpower resources in a few key industries to take advantage of economies of scale. Insufficient domestic demand for these industries' output could then be supplemented by demand for exports. The complementarities among sectors will also lead to the development of forward as well as backward 1 inkages. 8 Hirschran, in particular, emphasizes the role of entrepreneur in development. By cutting costs and improving quality, entrepreneurs grevent waste, free resources for use in productive areas of the economy and create a favorable atmosphere for further investments. 9 It may appear that unbalanced growth offers a more attractive approach to growth. But the matter is really not all that simple. The unbalanced growth policy requires that economy carefully choose among investment alternatives which is not an easy task. In the first place, potential leading sectors that could possibly serve as engine of growth must be available. Secondly, the leading sectors should be able to provide direct and indirect linkages with the rest of the economy.

\section{Dualistic Models}

Dualistic models have been developed to conceptualize the process of economic development of a less developed 
country. A typical dual economy is described in the works of W. A. Lewis, R. S. Eckaus, J. C. H. Fei, G. Ranis, and D. W. Jorgenson. In the classic situation, there are two main sectors. First, there is an agriculture sector which is assumed to be economically backward, using traditional methods of production, and exhibiting disguised unemployment. Second, there is an industrial modern sector. The traditional sector provides the dynamics for growth, by releasing its surplus labor for industry, as well as producing a food surplus for urban markets. By assuming zero marginal productivity of labor in the agriculture sector, Lewis believes that a large volume of labor may be transferred into the industrial production without loss of agriculture output. Under these conditions, the wage rate required to attract labor into the industrial sector need be only slightly above the productivity per hour in the agricultural sector. All the surplus product above the wages of labor in the modern sector accrues to the entrepreneurs. Profit expansion then stimulates new investments and higher levels of investment in turn enhances the economic growth.10 The Lewis model has been criticized for the assumption of an unlimited surplus of labor in the agriculture sector. Some economists argue that although many agricultural workers in less developed countries are underemployed they cannot be considered as surplus labor because their contribution to total production is far from zero. 
The model developed by $R$. S. Eckaus assumes that in the industrial sector development is capital intensive and factor proportions are relatively fixed. Thus an increase in employment can only be achieved by a proportionate increase in capital investment. In the agricultural sector, by contrast, technical coefficients are variable, implying that a wide range of methods and factor combinations can be employed to yield the same amount of output. The proportions actually used depend on the relative price and availability of labor and capital. Under these conditions, absorptive capacity of the industrial sector is limited, and given a population explosion, the increasing supply of labor should be channeled into the agricultural sector where it can be absorbed by the use of more labor-intensive techniques of production. Thus there is no incentive for modernization of the agricultural sector, and the structural gap between the two sectors widens as the economy grows. 11

The model of Fei. and Ranis explores not only the labor interrelation of the two sectors, but also the production of consumption and investment goods and services in both sectors. In contrast to Eckaus' model factor proportions are assumed to be variable in the industrial sector. Consequently, the economic growth may be achieved by accumulation of either or both capital and labor. But all technical innovation is assumed to take place in the industrial sector. Given these assumptions, economic development then 
requires a shift of resources from the agricultural sector to the industrial sector at a rate faster than the growth rate of the economy as a whole.12 Jorgenson criticizes many of the assumptions made by Fei and Ranis particularly the freedom of the industrial sector to absorb labor without a proportionate increase in capital. In Jorgenson's model the marginal productivity of labor in the agricultural sector is always positive and transfer of labor from the agriculture to the industrial sector causes loss to agricultural output, and the real wage rises continuously with economic growth.13

The Oil Exporting Dual Economy

The foregoing description of a dual economy differs distinctly from a dual economy in which there is an enclave modern sector of oil production. Basically we can characterize an oil exporting developing economy by an enclave modern oil sector, a growing industrial urban sector, and a stagnating agriculture sector. The most significant feature of the oil sector is its almost complete independence from the rest of the economy. Iittle contribution is being made by domestic sectors to the production of crude oil, in particular the participation of domestic labor force in the oil sector is negligible. Hence, oil revenues may be considered as collective economic rent. 14 oil income, however, makes up a large share of national income, and almost 
the whole of foreign exchange receipts. Oil revenues, therefore, can help to eliminate two major constraints of capital formation in developing countries. It generates sufficient savings and foreign exchanges to compensate for inadequate internal savings and export earnings. Petroleum also provides a source of energy. Inadequate supply of energy could hamper jndustrialization and put a great deal of pressure on the limited available foreign exchanges in a developing country.

Oil revenues are directly received by the government and the state has a great deal of flexibility in its disbursements. Once oil revenues make up ten percent or more of the national income, they create a relative political and economic independence from the indigenous social and economic forces for the state. In contrast to the classical case, the growth of an oil-exporting developing country depends on the public expenditures. Homa Katouzian believes that in the case of an oil exporting dual economy the most clear line of demarcation between different social and economic classes is not so much their relations with means of production, but their relations with the main supplier of the means of consumption, i.e., the state. Furthermore, he observes that:

The state's consumption expenditure will rapidly expand its own military-bureaucratic network, both in the size of its membership and its earnings; and bureaucratic earnings set the floor for earnings in other alternatives. These... lead to a high rate of consumption expenditures ... in the 
expansion of, in particular, bureaucratic and modern services, and also of construction and modern durable consumer goods...

State investment expenditures places great amphasis on the urban sector; it emphasises construction, modern service activities ... and heavy industries (steel, machine tools, and so on); and it employs the latest capital-intensive as well as skill-intensive-modern technology. 15

The lopsided allocation of oil revenues creates an imbalance in the economy. The agriculture sector is not capable of meeting the rapid rise in demand for food. This inability is partly due to technical and institutional constraints, and partly due to the intentional neglect in the development strategy. The urban food shortage can be met by increased imports which are possible thanks to the oil revenue. Nevertheless, the prices continue to rise because of inadequate supply of ports, storage and transport facilities. Given the scarcity of skilled labor, technicians, and managers, the desired production level cannot be realized through increasing investments in the urban sector. Hence, the rise in demand for durable consumer goods should be partially met by direct import. The rectification of this imbalanced economic situation may require a process of diversification of domestic output in order to reduce the country's dependence on imports of consumers' goods, intermediate goods and machinery. Small countries with relatively high oil reserves may afford to pursue a strategy of resource-based capital-intensive industrialization. 
Oil-exporting countries with moderate capital endowment, and larger populations, however, need to develop agriculture and small-scale industries along with resource-based industrialization in order to solve food as well as employment problems. The larger domestic market also allows more scope for development of basic heavy industries. To reduce the economy's dependence on oil, the creation of an alternative export sector should also be seriously considered. In this context, government plays a crucial role by channeling oil revenues into productive and appropriate investments. The private sector-public sector dichotomy, therefore reflects the importance of the oil sector in the development process.

Oil duality like classical duality should represent a transitional stage in the process of the economic development. As the sectoral integration of the economy increases, and indigenous technical and productive capacity improves, the oil sector gradually loses its dominant position in favor of the industrial sector and high oil-based growth should be replaced by a moderate self-sustained growth. 
ILawrence R. Klein, "What Kind of Macroeconometric Model for Developing Economies?" In Readings in Economic Statistics and Econometrics, ed. Arnold Zellner, (Boston: Little, Brown and Company, 1968), pp. 559-570.

2 Anthony S. Campagna, Macroeconomics Theory and Policy (Boston: Houghton Mifflin, 1974), pp. 430-432. Savings and output functions are expressed as
(1) $\quad \mathrm{S}=\mathrm{aY}$
(2) and $y=b K$
(3) $\quad b=\frac{Y}{K}=\frac{\Delta Y}{\Delta K}$

where

$$
\begin{aligned}
& \mathrm{S}=\text { savings } \mathrm{Y}=\text { output } \mathrm{K}=\text { capital stock } \\
& \mathrm{a}=\text { marginal (and average) propensity to save } \\
& \mathrm{b}=\text { inverse of capital output ratio. }
\end{aligned}
$$

By definition $\Delta K=I$ where $I=$ investment

Then I can be substituted for $K$ in equation (3) to give

$$
\mathrm{b}=\frac{\Delta \mathrm{Y}}{\mathrm{I}} \text { or } \Delta \mathrm{Y} \ddot{=} \mathrm{bI}
$$

which shows a growth in productive capacity. On the demand side, a growing economy must equate $\Delta S / \Delta Y$ and $\Delta I / \Delta Y$ as a moving equilibrium condition so that

$$
\frac{\Delta S}{\Delta Y}=\frac{\Delta I}{\Delta Y}=\text { or } \Delta Y=\frac{\Delta I}{a} \text { on the demand side. }
$$

For a balanced equilibrium growth,

$$
\mathrm{bI}=\frac{\Delta I}{\mathrm{a}} \text { and rearranging gives (4) } \frac{\Delta I}{\mathrm{I}}=\mathrm{a} \cdot \mathrm{b}
$$

3 A starting point for much of the growth literature is the Cobb-Douglas production function. This assumes a competitive economy with two homogenous factors of production, capital (K) and labor (L):

$$
Y=A^{a} L^{1-a}
$$

marginal productivities of capital and labor are derived as: 


$$
\frac{\partial Y}{\partial K}=a \frac{Y}{K} \text { and } \frac{\partial Y}{\partial L}=(1-a) \frac{Y}{L}
$$

Let the price of output be $\mathrm{P}$, the wage rate $\mathrm{W}$ and the price of capital I. Then profits, NR = P.Y-WL-IK will be maximized subject to the constraints imposed by the production function when

$$
\begin{array}{ll}
\frac{\partial N R}{\partial L}=P(1-a) \frac{Y}{L}-W=0 & \text { or } \quad(1-a) \frac{Y}{L}=\frac{W}{P} \\
\frac{\partial N R}{\partial K}=P a \frac{Y}{K}-I=0 & \text { or } \quad a \frac{Y}{K}=\frac{I}{P}
\end{array}
$$

These simply state that the marginal productivity of labor is equal to the real wage and that the marginal productivity of capital is equal to the price per unit of capital divided by the price of output. Capital output ratio and capital labor ratio are determined as

$$
\frac{K}{\bar{Y}}=\frac{a p}{I}, \frac{L}{K}=\frac{(]-a) I}{a(W)}
$$

Thus we see the basic economic fact that the ratio of labor to capital depends on the ratio of actor prices. Similarly the capital output ratio depends only on the ratio of the price of output to the price of capital.

Note that $a+(1-a)=1$. Thus it is required that there be constant returns to scale in the production function. This statement can be checked by multiplying the amount of capital and the amount of labor by a constant like c:

$$
Y=A(C K)^{a}(C L)^{1-a}=A^{a} L^{1-a} C(a+1-a)=C Y
$$

Thus if we multiply all inputs by 2 , we shall increase output by multiplying two fold.

Technolcgical change can be introduced by inserting a time trend as follows:

$$
\begin{aligned}
& Y=e^{r t_{A K} a_{L} 1-a} \quad \text { where } \\
& e=2.71828 \quad r t=\text { time rate of technological change. }
\end{aligned}
$$

Technological change is said to be labor saving if it raises the marginal product of capital relative to marginal product of labor. It is said to be capital-saving if it raises the marginal product of labor relative to the marginal product of capital. Finally, it is said to be neutral if it raises the marginal products of labor and capital in 
the same proportion. For more details see Warren L. Smith, Macroeconomics (Homewood, Illincis: Richard D. Irwin, Inc., 1970), pp. 401-422.

${ }^{4}$ Charles C. Kindleberger, Economic Development, Second Edition, (New York: McGraw-Hill Book Co., 1965).

5Hla Myint, "The Classical Theory of International Trade and the underceveloped Countries" in Economic Theory and the Underdevelopad Countries, ed. Hla Myint, (New York: Oxford University Press, 1971), pp. 118-146.

${ }^{6}$ Ragnar Nurske, Problems of Capital Formation in Underdeveloped Countries, (New York: University Press, 1953).

${ }^{7} \mathrm{P}$. N. Rosenstein-Rodan, "Notes on the Theory of the Big Push", in Economic Development for Latin America, (New York: St. Martin's Press, 1951).

${ }^{8}$ T. Scitovsky, "Two Concepts of External Economies" in The Economics of Underdevelopment, ed. A. N. Agarwala and S. P. Singh, (New Tork, 1963) pp. 295-308.

${ }^{9}$ A. O. Hirschman, The Strategy of Economic Development, (New Haven: Yale University Press, 1971).

10 W. A. Lewis, "Economic Development with Unlimited Supplies of Labour", Manchester School of Economics and Social Sciences, May 1954, pp. 139-91.

$11_{R}$. S. Eckaus, "The Factor Proportions Problem in Underdeveloped Areas", American Economic Review, 45 (1955), 539-65.

12J. C. H. Fei and G. A. Ranis, "A Theory of Economic Development", Americar Economic Review, 51 (1961), 533-64.

${ }^{13} \mathrm{D}$. W. Jorgenson, "The Development of a Dual Economy", Economic Journal, $71(1.961), 309-34$.

14M. A. Katozian, "Oil Versus Agriculture: A Case of Dual Resource Depletion in Iran", Journal of Peasant Studies, 5 (1978), 347-69.

15 Homa Katouzian, The Political Economy of Modern Iran, (New York: New York University Press, 1981), pp. 245-247. 
CHAPTER III

MACRO ECONOMETRIC MODELS OF DEVELOPING COUNTRIES WITH SPECIAL

REFERENCE TO MODELS OF IRAN

A great number of published models for developing economies have been constructed within the two-gap framework. The basic assumption of the two-gap approach is that most developing countries are faced with a shcrtage of domestic savings (saving gap) to meet the required investment expenditures or a shortage of foreign exchange (trade gap) to pay for needed imports. Foreign aid then can play an important role in supplementing domestic savings and assuring the import of required capital and intermediate goods and services from abroad.

Survey of Models for Iran

Some of the two-gap models for developing countries were undertaken by JNC'PAD ${ }^{1}$ and ECAFE ${ }^{2}$ and projections were made of external resource requirements of individual developing countries.

The main emphasis of these models are on the determination of the dominant gap and the estimates for the two gaps. While a two-gap model is conceptually useful and it is a frame of reference for the development aid, the preoccupation of model builders with the two-gap emphasis has 
led to the construction of mechanistic equations rather than descriptions of the economies under study. In UNCTAD, 1963, the model of Iran, given the rate of growth of GDP, and agricultural sector, is mainly concerned with the estimation of the compatible rate of growth of the oil sector, as well as rates of growth of imports and exports. 3 The UNCTAD model consists of thirty-two behavioral equations, and ten exogenous variables. The behavioral equations are represented by the seven consumption functions, two growth equations, two equations relating non-agricultural portion of GDP to oil sector, four oil exports functions, two other commodity and service functions, three production functions, seven import functions, two equations relating investment to exports of crude oil and products, and finally three equations illustrating relationship between oil sector and indirect taxes, net factor income from abroad, and the rest of the economy. Estimation of the model is performed by ordinary least squares (OLS) regression method. Annual data is used in the estimation for the period of 1956-63. Consequently the number of observations are limited to only eight observations. Linear and log equations are used in the model with lags up to one year. Haxrod-Domar type production functions are used for representing the supply side of the model. Import and export functions are fairly disaggregated, but there is no function for treatment of supply or demand of the labor force. 
Some behavioral equations are estimated using constant values while others run in current terms. Of a total of thirty-two regression equations twenty-nine have only one regressor and the rest have two regressors.

The model constructed by $F$. Vakil is based on Keynesian aggregate demand approach. The model consists of fourteen behavioral equations with ten exogenous variables. The model is estimated by ols over the period 1959-1971.4 Limited numbers of observations in Vakil's model as well as in UNCTAD, 1968 precluded the application of consistent regressors such as two-stage least squares (TSLS), and as a result some of the estimated coefficients may suffer from a simultaneity bias, due to the correlation between the error term and independent variables. Furthermore, the coefficients of these models as indicated by t-statistics have a very limited significance and thus should be used with great caution. In Vakil's model all variables are measured in current prices. Thus any projection based on the estimated structural equations will include a price inflation factor. The aggregate demand includes three equations for consumption, three investment equations, two export functions, and two equations for imports. The model also includes equations for net factor income from abroad, private sector credit, tariff revenues and taxes. There is however no equation to represent the supply side of the economy. 
The A. Shahshahani and J. M. Dowling model is basically a demand oriented system of equations. However an attempt has been made to incorporate some of the features of an oil-exporting dual economy as well as capital and credit markets through specjal equations. The monetary side of the economy is represented by a money supply function and a price equation. On the supply side there is only one equation which reflects the relationship between the value added in the agricultural sector and the total population. Annual data is used in all cases and the model is fitted for the period of 1959-73. Variables are measured in constant as well as current prices. 6 Because of the limited number of sample observations and a large number of predetermined variables, a variant of TSLS is used to estimate the coefficients. In addition, the problem of autocorrelation and autoregression, namely the presence of lagged dependent variables on the right side of the equations, are left untreated. All these problems reduce further the reliability of the estimated coefficients.

For a more systematical comparison, see the tabular survey of models for Iran at the end of this chapter.

Desired Characteristics of a Macroeconometric Model for an Oil-Exporting Dual Economy

Econometric models of developing countries have attracted great attention as tools for planning projections and policy formulation, but the quality of the models 
constructed have not been very satisfactory, very often necessarily so in view of the general lack of data, low quality statistics and the lack of an appropriate and generally accepted theory of development. 6 H. C. Bos advocates construction of the small models which capture the essential features of the economy. 7 He believes that:

Big models get out of hand. They cannot be explained or documented. They cost a fortune to run. They require data that cannot be found. They are black boxes full of undetectable errors. 8

Bos states that the factors of production and supply constraints including skills of various types are the main determinants of economic growth of developing countries. Thus the standard short run Keynesian model of effective demand must be reconsidered to place more emphasis on supply equations. Klein, on the other hand, suggests extending detail on the supply side through the use of input-output data in conjunction with final demand.9 An objection to such an approach is the fact that precisely in the case of developing countries, interindustry flows are simply too weak to be of any importance. Furthermore, this type of model will have to become very large if they are to present any advantage over smaller and more simple models.

Models for the developing countries in general and those of the oil-exporting countries in particular, must reflect dual nature of those economies. Agriculture plays an important role, and it is very desirable then to underline 
this sector through the appropriate supply, demand, and employment equations. Thus both supply and demand are brought into play while their specifications will vary from country to country. In a Keynesian model, the role of a production function is to determine the level of labor that is required to produce output that is demanded. In most developing countries labor is plentiful, though skilled labor is lacking. Thus it is of great importance to find out the level of output that could be produced through the combination of the scarce resource which is capital and abundant unskilled labor.

The foreign sector plays a large and significant role in developing economies in general and oil-exporting countries in particular, and should therefore figure prominently in econometric models of these nations. In view of the import substitution strategies of many developing countries, and demand forming function of imports, it is desirable to subdivide imports into two distinct categories of consumer goods imports, and capital and intermediate goods imports. In the case of oil-exporting countries the export sector must be also appropriately divided into oil and nonoil exports.

In most developing countries financial sources consist of entirely a few commercial banks. Comnercial banks, however, are more suited to provide short term rather than long term loans which fit perfectly the needs of the 
service sector. Other financial intermediaries and capital markets are simply nonexistent or are in the embryonic stage. In the case of developed countries the most logical way of linking monetary sector with the real part in a model seems to be through the investment function. In the Keynesian model, the link between the real and the monetary sector is provided by the interest rate which appears in the investment specifications. In the developing economies, as we have already mentioned, there are no capital markets to speak of and interest rates do not represent the cost of borrowing funds since these funds are basically rationed rather than auctioned. In the case of oil-exporting countries, a large part of investments are carried out by the public sector and private sector investments are guided almost exclusively by government economic development policies. In addition, government has been the supplier of foreign exchange and low-interest credit. Therefore, for all practical purposes, investment expenditures can be assumed independent from the market interest rates and may be incorporated into the model as exogenous variable.

Oil revenues make up a large share of national income and virtually the whole of foreign exchange receipts in the oil-exporting countries. Government receives and disburses the oil revenue. As a result the growth of an oil exporting country to a large extent depends on the public 
expenditures. Therefore it is quite necessary to include the government consumption expenditures as a separate and distinct equation in the riodel. 


\section{TABLE I}

SUMMARY OF MAIN CHARACTERISTICS OF THE UNCTAD, 1968 MODEL FOR IRAN

\begin{tabular}{|c|c|}
\hline Data & $\begin{array}{l}\text { Annual, 1956-63, current prices. Source: } \\
\text { various puolications of Bank Markazi Iran and } \\
\text { Ministry of Economy. }\end{array}$ \\
\hline $\begin{array}{l}\text { Number of } \\
\text { Behavioral }\end{array}$ & $\begin{array}{l}\text { 32: } 1 \text { consumption function, } 2 \text { growth equa- } \\
\text { tions, } 2 \text { non-agricultural GDP equations, } 4 \\
\text { oil export equations, } 2 \text { non-oil export equa- } \\
\text { tions, } 7 \text { import functions, } 3 \text { GDP equations, } 2 \\
\text { investment functions, and } 3 \text { equations relat- } \\
\text { ing oil sector to indirect taxes, net factor } \\
\text { income from abroad and rest of the economy. }\end{array}$ \\
\hline $\begin{array}{l}\text { Number of } \\
\text { Exogenous }\end{array}$ & $\begin{array}{l}\text { 10: Value added in the oil sector, value } \\
\text { added in agriculture, value added in the rest } \\
\text { of the economy, aggregate investment, produc- } \\
\text { tion of crude oil, export of oil, GDP at mar- } \\
\text { ket price, GNP at factor cost, total non-oil } \\
\text { exports, total imports. }\end{array}$ \\
\hline Estimation & $\begin{array}{l}\text { OLS, estimated coefficients suffer from } \\
\text { simultaneity bias, limited significance of t- } \\
\text { statistics, problems of autocorrelation and } \\
\text { lagged dependent variables are left un- } \\
\text { treated. }\end{array}$ \\
\hline
\end{tabular}


TABLE I (continued)

\begin{tabular}{l|l}
\hline $\begin{array}{l}\text { Validation } \\
\text { of the }\end{array}$ & \\
Model & None \\
\hline Objectives & \\
and Special & Determination of the saving and trade gaps. \\
Features & Detul
\end{tabular}


TABLE II

SUMMARY OF MAIN CHARACTERISTICS OF THE VAKIL, 1974 MODEL FOR IRAN

\begin{tabular}{|c|c|}
\hline Data & $\begin{array}{l}\text { Annual, 1959-71, current prices. Source: } \\
\text { Publications by Bank Markazi Iran. }\end{array}$ \\
\hline $\begin{array}{l}\text { Number of } \\
\text { Behavioral } \\
\text { Equations }\end{array}$ & $\begin{array}{l}14: 3 \text { consumption functions, } 3 \text { investment } \\
\text { equations, } 2 \text { export equations, } 2 \text { import } \\
\text { equations, } 2 \text { equations for taxes, an equation } \\
\text { for private sector and one for net income } \\
\text { from aoroad. }\end{array}$ \\
\hline $\begin{array}{l}\text { Number of } \\
\text { Exogenous } \\
\text { Variables }\end{array}$ & $\begin{array}{l}\text { 10: Value added in agriculture, rural popu- } \\
\text { lation, value added in oil, lagged GNP, } \\
\text { lagged capital imports, wholesale price in- } \\
\text { dex, lagged oil exports, lagged value added } \\
\text { in manufacturing, value added in manufactur- } \\
\text { ing, lagged money supply. }\end{array}$ \\
\hline Estimation & $\begin{array}{l}\text { OLS, estimated coefficients suffer from } \\
\text { simultaneity bias, limited significance of t- } \\
\text {-statistics, problems of autocorrelation and } \\
\text { lagged dependent variables are left } \\
\text { untreated. }\end{array}$ \\
\hline of Model & None \\
\hline
\end{tabular}


TABLE I I (continued)

\begin{tabular}{l|l}
\hline Objectives & Forecasting future trends of main macroecon- \\
and special & omic variables for policy analysis. \\
Features &
\end{tabular}


TABLE III

SUMARY OF MAIN CHARACTERISTICS OF THE SHAHSHAHANI, 1976 MODEL FOR IRAN

\begin{tabular}{|c|c|}
\hline Data & $\begin{array}{l}\text { Annual, 1959-73, some variables in constant } \\
\text { and some in current prices. Source: various } \\
\text { publications of Bank Markazi Iran. }\end{array}$ \\
\hline $\begin{array}{l}\text { Number of } \\
\text { Behavioral } \\
\text { Equations }\end{array}$ & $\begin{array}{l}\text { 17: } 3 \text { consumption functions, } 3 \text { investment } \\
\text { equations, } 3 \text { import equations, } 1 \text { export } \\
\text { equation, } 3 \text { equations for taxes and govern- } \\
\text { ment revenues, } 4 \text { equations for money supply, } \\
\text { price index, net income from abroad and value } \\
\text { added in agriculture. }\end{array}$ \\
\hline $\begin{array}{l}\text { Numioer of } \\
\text { Exogenous } \\
\text { Variables }\end{array}$ & $\begin{array}{l}\text { 13: Money supply, population in agriculture, } \\
\text { total population, oil revenue received oy } \\
\text { Plan Organization, total oil revenue, terms } \\
\text { of trade, total exports, oil exports, lagged } \\
\text { government consumption, lagged urban consump- } \\
\text { tion, lagged government investment, lagged } \\
\text { imports of consumer goods, lagged change in } \\
\text { value added in manufacturing. }\end{array}$ \\
\hline $\begin{array}{l}\text { Estimation } \\
\text { Method }\end{array}$ & $\begin{array}{l}\text { ILS, t-statistics of limited significance, } \\
\text { problems of autocorrelation and lagged de- } \\
\text { pendent variables are left untreated. }\end{array}$ \\
\hline
\end{tabular}


TABIE III (continued)

\begin{tabular}{l|l}
\hline $\begin{array}{l}\text { Validation } \\
\text { of the }\end{array}$ & \\
Model & None \\
\hline Objectives & Forecasting future trends of main macroecon- \\
and Special & omic variables for policy analysis. \\
Features &
\end{tabular}


TABLE IV

SUMMARY OF MAIN CHARACTERISTICS OF THE HEIAT, 1986 MODEL FOR IRAN

\begin{tabular}{|c|c|}
\hline Data & $\begin{array}{l}\text { Annual, 1959-76, constant prices. Source: } \\
\text { Economic Trends of Iran, Plan and Budget } \\
\text { Organization, } 1978 .\end{array}$ \\
\hline $\begin{array}{l}\text { Number of } \\
\text { Benavioral }\end{array}$ & $\begin{array}{l}\text { 12: } 3 \text { supply functions for agriculture, } \\
\text { urban and oil sectors, } 3 \text { consumption func } \\
\text { tions for rural, urban and government } \\
\text { sectors, } 2 \text { import functions, } 2 \text { employment } \\
\text { equations, and } 2 \text { equations for non-oil ex- } \\
\text { ports and indirect taxes. }\end{array}$ \\
\hline $\begin{array}{l}\text { Exogenous } \\
\text { Variacles } \\
\quad+ \\
\text { Lagged } \\
\text { Dependent }\end{array}$ & $\begin{array}{l}\text { 15: Lagged value acided in urban and agricul- } \\
\text { ture sectors, investments made in urban and } \\
\text { agriculture sectors, growth in labor employed } \\
\text { in agriculture sector, growth in land under } \\
\text { cultivation, lagged urban and agriculture } \\
\text { consumptions, urban and rural populations, } \\
\text { lagged government consumption, lagged import } \\
\text { of consumer goods, lagged investments made in } \\
\text { urban sector, export of oil, and time trend. }\end{array}$ \\
\hline $\begin{array}{l}\text { Estimation } \\
\text { Method }\end{array}$ & $\begin{array}{l}\text { OLS and TSLS, correctional procedures were } \\
\text { used to deal with the problems of autocorre- } \\
\text { lation and lagged dependent variables. } \\
\text { Theil's h-statistics calculated. }\end{array}$ \\
\hline
\end{tabular}


TABLE IV (continued)

\begin{tabular}{|c|c|}
\hline $\begin{array}{l}\text { Validation } \\
\text { of the } \\
\text { Model }\end{array}$ & $\begin{array}{l}\text { Historical simulation of the model is per- } \\
\text { formed to test the validity of the model. }\end{array}$ \\
\hline $\begin{array}{l}\text { Objectives } \\
\text { and special } \\
\text { Features }\end{array}$ & $\begin{array}{l}\text { Tests empjrically the relevance and applic- } \\
\text { ability of several conventional consumption } \\
\text { and production models to the Iranian economy. } \\
\text { Marginal propensities in consumption and pro- } \\
\text { duction equations are estimated for planning } \\
\text { and policy analysis purposes. Impact and } \\
\text { dynamic multipliers for several macroeconomic } \\
\text { variables are calculated and discussed. }\end{array}$ \\
\hline
\end{tabular}


NOTES

IUnited Nations, Trade Prospects and Capital Needs of Developing Countries, (New York: UNCTAD, 1968). This study contains models for 18 developing countries.

2 United Nations, Feasible Growth and Trade Gap Projections in the ECAFE Region, (Bankog: ECAFE, 1968). This study contains models for ten countries. ECAFE also has published a study entitled, Sectoral Output and Employment Projections, (Bankog: ECAFE, 1970). This study contains nine countries including Iran.

${ }^{3}$ United Nations, 1968, pp. 322-323.

${ }^{4}$ Firouz Vakil, "An Econometric Model for Iran", Bank Markazi Iran Bulletin, 11 (1972), pp. 115-120; Firouz Vakil, "An Econometric Model for Iran: Estimated Structural Equations", Bank Markazi Iran Bulletin, 11 (1973), pp. 633-655.

${ }^{5}$ Ahmad Shahshahani and J. Malcolm Dowling, "An Econometric Model Forecast of Iran, 1975-1985", The Journal of Energy and Development, Autumn, 1976, pp. 148-161.

${ }^{6}$ Henk C. Bos, "Some Simple Thoughts on Model Building for Developing Countries", The Pakistan Development Review, 22 (1983), pp. 63-71.

$7_{\text {Bos, p. }} 66$.

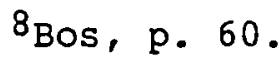

${ }^{9}$ Lawrence R. Klein, "What Kind of Macroeconometric Model for Developing Economies?" in Readings in Economic Statistics and Econometrics, ed. Arnold Zellner (Boston: Little, Brown and Company, 1968), pp. 559-570. 
CHAPTER IV

STRUCTURAL CHARACTERISTICS OF THE IRANIAN ECONOMY

During 1959 and 1976 the Iranian economy experienced a rapid growtin in terms of real gross national product. Tables presented in Appendix A give a summary of quantitative changes and structural shiits in the Iranian economy over the four successive development plans. We do not feel it is necessary to present a discussion of these plans partly because information included in Appendix A gives a clear picture of the pattern of structural changes of the Iranian economy during the 1959-1976 period, but mainly because they have been discussec in detail elsewhere. Interested readers, therefore, may consult numerous studies which exist in the 1 iterature. 1

This chapter is devoted to a brief theoretical discussion of an aggregative econometric model of the Iranian economy. The specification of the model and of the individual equations is determined by three main considerations: the availability of data, the underlying theory, and constraints of the Iranian economy. Therefore, after making some brief remarks about the characteristics of the economy, we will concentrate on the economic and logical aspects of the model. In the next chapter, the main concern 
will be the empirical results and the statistical methods involved in specifying and estimating the model.

\section{Characteristics of the Economy}

The most distinctive feature of the Iranian economy is the dominant role played by the oil sector in financing the public expenditures as well as development projects. Thus it is reasonable to expect that government policies should be directed toward the transformation of the dynamic oil sector into an engine of growth. 2 However during 19591976 the forward and the backward linkage effects of the oil sector on the Iranian economy were very weak. In other words, the oil industry remained almost independent from the domestic means of production and the linkages between the oil sector and the rest of the economy were only through state consumption and investment expenditures.

The flow of resources between the oil sector and agriculture sector was the weakest, while that of the foreign sector was the strongest of all. The direct forward and backward linkages of the oil sector with the industrial sector were also insignificant. But the state investment expenditures placed great empinasis on the urban sector. It emphasized construction, modern services, heavy industries and modern consumer oriented light industries. It employed the latest capital-intensive as well as skill-intensive modern technology, but after almost two decades of 
importing expensive machinery and foreign expertise, the Iranian economy anded up mitn "hollow" industries. These were industries that did little or no domestic manufacturing, and lacked their own pioduction base.

This being the case, an econometric model for an oil exporting country like Iran should reflect the flow of the financial resources from the oil sector to the rest of the economy, rather than the opposite direction suggested by Lewis, Fei-Ranis and Jorgenson type models, where the flow of resources are from the agriculture sector to the other indigenous sectors. Furthermore, surplus resource in an oil exporting country in contrast to labor surplus economy is exhaustible and the supply of trained labor force and skilled managers is very limited. So in general it may be argued that in order to generate direct linkages between the oil sector and the rest of the economy, inaigenous production capacity of industry as well as of agriculture sectors should be expanded through diversification and increase in the productivity of these sectors, and developing a large pool of skilled labor. This strategy is not however easy to impiement; it would take too long and its planning and execution would require the kind of administration and dedication which did not exist in Iran during the period under consideration.

As we discussed in Chapter II, the additional productive capacity in developing countries creates its own 
demand. But in the case of Iran and most of the oil exporting developing nations, a large proportion of income received by urban households, particularly those in higher income groups is not due to their own productive effort. That is why the Iranian economy consumed the equivalent of nearly all that it produced. In other words, the total output of agriculture, industry and services was almost equal to consumption of goods and services. It is assumed that as the economy develops, the oil-based growth will be replaced by a moderate consumption-based growth which is generally the case in the industrialized countries. 3 This orientation toward a consumption-based economy was in accordance with the modernist approach to development which believes that the higher living standards must be the primary goal of the developing countries. 4 This consumptionbased orientation toward the economy in an oil-exporting country like Iran resulted however, in a concentration of both private and state consumption expenditures in urban areas in the form of growing consumption of cars, home appliances, palatial housing, and entertainments offered by restaurants and night clubs by the higher income groups in the capital and a few large cities. In this study we cannot consider the consumption behavior of different income groups, but the available data provide some information about the broader aspects of private and public consumption in Iran during 1959-1976. The private consumption can be 
divided into rural and urban categories; and the role of the government is reflected through a separate consumption function which emphasizes the oil sector as a major determinant of government expenditures.

In view of the fact that the development process in a developing country like Iran was not based on innovation but on the assimilation of the existing technology through importation of modern capital equipment, semi-finished parts and raw materials, two different functioris for imports of goods and services and imports of capital and intermediate goods are included in the model. Exports may also be disaggregated into oil and non-oil exports which represent the dominant role of the oil sector in the foreign trade.

\section{Specification of the Model}

In the econometri.c model that follows, an attempt has been made to elucidate the mechanisms of the Iranian economy. Some of the concerns of the last two chapters are incorporated in the model. But other concerns are not adequately treated. Considerable compromises have been made between constructing an ideal model of an oil-exporting dualistic economy and the available data. These compromises have been most substantial with respect to demographic and institutional factors, infrastructure, capital 
and capacity restraints in production sectors, distribution of income and rural-urban migration.

On the other hand, the model does include a number of important considerations of the last two chapters. The conventional duality which distinguishes between the traditional rural and the modern urban sector as well as private and public duality reflecting the importance of the oil sector are represented in the consumption, supply, employment and foreign trade equations.

The structural model consists broadly of five subsystems :

(a) consumption expenditures

rural private

urbar private

government

(b) Eoreign trade

imports of consumer goods

imports of capital and intermediate goods

non-oil exports

(c) production (value added)

value added in agriculture

value added in urban sector

value added in oil sector

(d) employment

labor employed in agriculture sector

labor employed in urban sector 
(e) Indirect taxes

net indirect taxes

The proposed model for Iran consists of two parts: demand and supply. On the demand side, consumption and imports are analyzed. Investments made in agriculture and urban sector are assumed to be exogenous in respect to the model. There are two basic reasons for making this assumption. First, the model is only concerned with the real part of the Iranian economy and monetary factors such as interest rate, supply of money and credits are excluded from the model. Second, in contrast to the classical case, in an oil-based economy, investments largely depend on the oil revenue and public expenditures and hence are independent from output and production capacity.

The supply side of the model includes supply equations for value added in agriculture, value added in urban sector, and value added in oil sector. Given the agriculture and urban employment functions, and indirect taxes equation, there are a total of seventeen endogenous variables and a total of seventeen equations which make the model a complete system.

There are thirty-two variables in all, fifteen of which are predetermined, consisting of seven lagged endogenous variables and eight exogenous variables. 
List of Variables

(a) Endogenous Variables

VAA value added in agriculture

GVAU growth in value added in urban sector

VAO value added in oil sector

NIT net indirect taxes

CR private rural consumption

CU private urban consumption

CG government consumption expenaitures

IMC imports of consumer goods

IMK imports of capital and intermediate goods

EXNO exports of non-oil goods

I.A labor employed in agriculture

GIU growth in labor employed in urban sector

VAU value added in urban sector

GDP gross domestic product

EX total exports

IM total imports

LU labor employed in urban sector

(b) Predetermined Variables

Exogenous

INVA investment made in agriculture

GLA growth in labor employed in agriculture

GLAND growth in area under cultivation

INVU investment made in urban sector 


INVU1 investment made in
year
POER rural population
POPU urban population
EXO exports of oil

\section{Lagged Endogenous}

VAAl value added in agriculture lagged one year VAUl value added in urban sector lagged one year

CRI rural consumption lagged one year

CU1 urban consumption lagged one year

IMC1 imports of consumer goods lagged one year

LU1 labor employed in urban sector lagged one year

CG1 goverrment consumption lagged one vear

\section{Consumption Expenditures}

The consumption function is mostly a Keynesian invention though the relation was known before keynes. According to the "fundamental psychological law" suggested by Keynes, people will increase their consumption as income increase, but not by as much as the increase in income. 5 From this and other assumptions the consumption function may be summarized as follows:

(a) Aggregate consumption may be a function cf a number of variables, but income is the most significant one, and hence we have:

$$
C_{t}=f\left(Y_{t}\right) \quad \text { where }
$$


$C=$ real consumer expenditures

$Y=$ real disposable income

(b) The money value of the wealth affects the short run propensity to consume of the "Wealth owning class".

(c) The short run marginal propensity to consume (MPC) is less than the long run MPC, because the consumer's habitual standard of living is more flexible in the long run than in the short run.

(d) Even in the long run, "as a rule a greater proportion of income (will be) saved as real income increases". 6

During the post world war II era, the $c=a+b y$ $a>00<b<1$ function was usea to predict the behavior of consumption in industrialized countries. $Y$ is the per capita disposable income and $b$ is the MPC, which is assumed to be less than average propensity to consume (APC or $C / Y$ ). APC is also assumed to decline as income rises. This version does not distinguish between the short run and long run MPC and does not allow for the effect of wealth on consumption. It invariably underestimated the consumption during the post war period in the industrialized economies when time series data were used to predict the consumption behavior. Later studies by Kuzenets and others showed the long run constancy of APC instead of its decline as income increases. 7 
Cross section data, on the other hand supported the above formulation and fitted industrialized countries data rather well. This paradox led to a great deal of research to find a more appropriate explanation of consumption function ano the reconciliation of the time series and cross section results.

Brown hypothesized that people do not adjust their consumption to changes in income immediately, but the process takes place slowly and habit is an important factor jin consumption. Therefore, Brown suggested the following formulation:

$$
c_{t}=a+b y_{t}+a c_{t-1}
$$

Where $C_{t-1}$ is the consumption in the previous period used as proxy variable for habit.

Another work attempting to provide a better understanding of consumption is Duessenberry's Relative Income Hypothesis. He argued that consumers tend to follow their habitual patterns of behavior. As income increases, they consume more but adjust slowly to their new affluence. On the other hand, when income drops, they resist any lowering of consumption standards to which they have become accustomed. 8

One of the most important studies done in terms of consumption function is that of Friedman's Permanent Income Hypothesis (PIH). It brings time into consideration and tries to explain the consumption behavior in terms of 
expected future incomes. According to Friedman, people determine their purchases called permanent consumption in accordance with their permanent income and in fact proportional to it. Permanent income is defined as the amount the consumer would consume which would leave his wealth intact. Permanent consumption, on the other hand, is the amount the consumer is intended to consume. So it is hypothesized, by generalization, that aggregate permanent consumption is proportional to aggregate permanent income. The factor of proportionality itself depends on the rate of interest, and taste:

$$
C_{P}=K Y_{P}
$$

Where $\mathrm{K}$ is the factor of proportionality. 9 The $\mathrm{C}_{\mathrm{P}}=$ $\mathrm{KY}_{\mathrm{P}}$ equation cannot be used for empirical estimation by time series. Permanent consumption does not present much problem, since it is nearly equal to actual consumption, and the latter may be used as a proxy for permanent consumption. A proxy must be found for permanent income, since it includes future earnings that are not known in advance. Past incomes, however, would best approximate the future incomes and geometrically declining weights are used for these incomes to attach less importance to the most distant incomes. Consumption is, therefore, expressed as function of lagged values of income. But the numbers of observations, from time series required to estimate this equation is large and cannot be used for our purposes. To overcome 
this problem Koyck transformation is perfor...d to get an alternative format with less coefficients to be estimated. 10 The new format is

$$
C_{t}=b^{\prime} Y_{t}+d^{\prime} C_{t-1}
$$

If we compare this equation with the Brown's Formulation of consumption function, we could see that the difference is only in the constant $a$, which is included in Brown's Formulation and not in Friedman's equation:

$$
\begin{array}{ll}
\text { Brown } & c_{t}=a+b Y+d C_{t-1} \\
\text { Friedman } & c_{t}=b^{\prime} y+d^{\prime} C_{t-1}
\end{array}
$$

The difference is important since only Frieaman's hypothesis states that $A P C$ is constant in the long run and is equal to long run MPC. Notice should be taken of the fact that the constant long run APC contradicts the Keynes' notion of APC. Both Eriedman's and Brown's hypothesis distinguishes between short run and long run MPC's. Short run MPC for Friedman's equation is equal to $b^{\prime}$ and for Brown's it is equal to b. If the consumption grows at the rate of $g$ per year (ignoring short-term fluctuations), then long run MPC's can be found by putting

$$
\begin{aligned}
& c_{t}=(1+g) c_{t-1} \\
& c_{t-1}=\left(\frac{1}{1+g}\right) c_{t} \text { in both equations }
\end{aligned}
$$

Long Run MPC (Brown) $=\frac{b(l+g)}{1+g-d}$

Long run MPC (Friedman) $=\frac{b^{\prime}(1+g)}{1+g-d^{\prime}}$ 
Several other interesting theories introducing wealth, liquid assets and distribution of income into determination of consumption function are to be skipped largely on the grounds of unavailability of Iranian data for their empirical estimation.

we used Keynesian, Brown's and Friedman's formulations to estimate consumption behavior in the Iranian economy. Taking into consideration the basic characteristics of the Iranian economy, we tried to disaggregate the consumption function into three different equations, where the "oil" and "urban-rural" auality are emphasized.

The urban-rural duality which is represented by coexistence of a relatively large, stagnant agriculture sector with a relatively small but growing and active urban sector is reflected by dividing the private consumption into rural and urban consumption functions. The oil duality is emphasized by introducing the oil exports as a major determinant of the government consumption expenditure equation. The consumption relationships are as follows:

Rural

$$
\begin{aligned}
& C R=a+b V A A \\
& C R=a+b V A A+d C R 1+\text { ePOPR } \\
& C R=b^{\prime} \text { VAA + } d^{\prime} C R 1+e^{\prime} P O P R
\end{aligned}
$$

Urban

$$
C U=a+b V A U+e P O P U
$$




$$
\begin{aligned}
& C U=a+b V A U+a C U 1+\text { ePOPU } \\
& C U=b^{\prime} V A U+d^{\prime} C U 1+e^{\prime} \text { POPU }
\end{aligned}
$$

Government

$$
C G=a+b C G 1+d N I T
$$

The rural consumption function describes the consumer's expenditures in the rural areas in terms of value added in agriculture (VAA), rural consumption lagged one year (CRI) and rural population (POPR), Value added ir agriculture is a good proxy for disposable income in the rural sector, in which subsistence conditions and a barter type transactions prevails.

The urban consumption function describes the consumption expenditure of the dynamic non-subsistence sectors of the economy. Here again the value added in urban sector is used as a proxy for urban disposable income. Its inclusion is basically justified, since the collected direct income taxes are not significart, and households to a large extent relate their consumption expenditures to value added in urban sector.

The government consumption expenditure (CG) which consists of the government's purchases of goods and services are not usually subject to the same type behavioral constraints as private consumption. Little is known about the behavior of public expenditures and they may be assumed to be autonomous or a simple function of taxes collected. However, in the case of Iran, in the absence of disaggregated 
data on CG, and lack of consistent series on direct taxes we consider CG to be dependent on the net indirect taxes and immediately preceding level of CG. The unaerlying theoretical justification is the idea that CG is subject to a previously established level of expenditures, as well as the current level of taxes. The inclusion of CG in the model emphasizes the private-public sector auality discussed before by reflecting the importance of the public sector as a major contributor to the total expenditures.

\section{Foreign Trade Relations}

The foreign trade relations consist of imports and exports of non-oil commodities.

In general imports are related to changes in national income and the price of imported commodities relative to domestic goods. For instance, in the model developed by Klein, imports are a function of changes in real income, lagged value of imports and the ratio of import prices to domestic prices. Thinking along the same lines, exports are related to the volume of world trade and the ratio of export prices to domestic prices. 12

However, for a developing country like Iran who was following a strong policy of import substitution over the period under consideration, total imports may conveniently be divided into consumer goods imports (IMC), and capital and intermediate goods imports (IMK). This division 
delineates those goods intended to currently increase the level of material welfare and those intended to further economic growth.

The export sector has been appropriately divided into oil and non-oil. This division carries an important rationale from the point of view of the oil-based strategy of economic development pursued by the pre-revolutionary government of lran. Since the oil sector had virtually been independent from the rest of the Iranian economy, and the export of oil as well as its price were determined by factors outside the system, EXO is assumed to be an exogeneous variable.

The import and export relationships are as follows:

$$
\begin{aligned}
& \text { IMC }=a_{0}+a_{1} \text { GDP }+a_{2} \text { IMC1 } \\
& \text { IMK }=b_{0}+b_{1} \text { INVU }+b_{2} \text { VAUI } \\
& \text { EXNO }=c_{0}+c_{1} \text { VAA }
\end{aligned}
$$

Imports of consumer goods, IMC, were assumed to be a function of gross domestic product and lagged imports of consumer goods. GDF is serving as a proxy for aggregate income. Since consumer goods are purchased mainly by consumers, the lagged import term is also relevant because it reflects the habits in consumer behavior as well as purchasing patterns of businessmen.

Imports of capital and intermediate goods were assumed to be a function of both private and public investment in 
urban sector and value added in urban sector lagged one year. This formulation is justified because in the case of Iran IMK is largely a function of import substitution policies aimed at a rapid industrialization process, rather than an incremental process inherent in the supply and demand mechanism.

Non-oil exports are assumed to be simply a function of value added in agriculture. The value added in agriculture is meant to be a proxy for traditional exports such as dried fruits, carpets and caviar, etc. The VAA also proxies the growth of agri-business activities and otiner light consumer goods industries which are traditionally the initial activities of industrialization in most developing countries.

\section{Production Functions}

The traditional theory specifies total output as a function of two inputs, capital stock and labor. Capital and labor are assumed to be continuous (and twice differentiable) and substitutable variables in production at all times. Problems associated with this kind of highly aggregated production functions are very well known and are discussed extensively in the li erature. However, production could be aisaggregated into sectoral functions such as manufacturing, mining, construction and so forth. But unfortunately disaggregated capital input data are not available 
for the Iranian economy, and the data for aggregated capital stock for the whole economy are calculated based on very simplistic assumptions and hence are not very reliable. 13

A further possibility is to estimate the supply function by breaking down the total output into sum of four components. In the case of urban sector the factors which influence the current output may bo broken down into value added in the urban sector lagged one year which serves as proxy for the production capacity of the urban sector in the previous period, investments made in the urban sector, increase in labor employed in urban sector and other factors as represented by constant terms. In the case of agriculture sector, in adilition to the foregoing factors changes in the land under cultivation should also be included.

In our model the following linear supply functions are suggested for the agriculture and urban sectors:

$$
\begin{aligned}
& \text { VAA }=a_{0}+a_{1} \text { VAA1 }+a_{2} \text { INVA }+a_{3} \text { GLA }+a_{4} \text { GLAND } \\
& \text { VAU }=b_{0}+b_{1} \text { VAU1 } 1+b_{2} \text { INVU1 } 1+b_{3} \text { GLU }
\end{aligned}
$$

where $\quad a_{1}=b_{1}=1$

Notice that since coefficient of VAU1 is assumed to be unity, the actual specification of the supply function for estimation purposes can be derived as follows

$$
\text { VAU }=b_{0}+\text { VAUI }+b_{2} \text { INVU1 }+b_{3} \text { GLU }
$$

subtracting VAU1 from the both sides 


$$
\begin{gathered}
\text { VAU - VAUI }=b_{0}+b_{2} \text { INVUI }+b_{3} \text { GLU } \\
\text { let GVAU = VAU - VAUI }
\end{gathered}
$$

where GVAU = growth of value added in urban sector

then

$$
\mathrm{GVAU}=\mathrm{b}_{\mathrm{O}}+\mathrm{b}_{2} \text { INVU1 }+\mathrm{b}_{3} \mathrm{GLU}
$$

is the estimation form of our supply function.

Value added in oil sector is simply assumed to be a function of exports of oil

$$
\mathrm{VAO}=\mathrm{C}_{\mathrm{O}}+\mathrm{C}_{1} \mathrm{EXO}
$$

\section{Employment}

The following equations are used to describe the labor employed in both agriculture and urban sectors:

$L A=a_{0}+a_{1}$ INVU1 $+a_{2}$ INVA
$L U=b_{0}+b_{1}$ LU1 $1+b_{2}$ INVU1

assuming $b_{1}=1$ then $\mathrm{GLU}=\mathrm{b}_{0}+\mathrm{b}_{2}$ INVU1

Labor employed in agriculture is expressed to be a function of investments made in agriculture (INVA) as well as investments made in the urban sector. Growth in labor employed in urban sector depends on the investments made in the urban sector lagged one year.

\section{Indirect Taxes}

Since there are no sales taxes in Iran, custom taxes comprise a great portion of indirect taxes collected by the 
government. Net indirect taxes, therefore, may be assumed to be a function of value of total imports:

$N I T=d_{0}+d_{1} I M$ 
NOTES

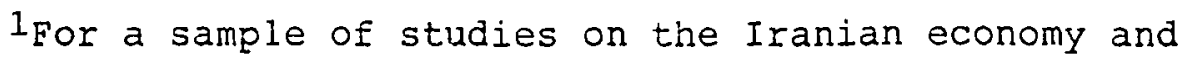
its development see J. Amuzegar and M. A. Fekrat, Economic Development Under Dualistic Conditions, (Chicago: University of Chicago Press, 1971); J. Amuzegar, Iran, An American Profile, (Washington, D.C.: Middle East Institute, 1977); J. Bharier, Economic Development in Iran: 1900-1972, (New York: Oxford University Press, 1971); R. Looney, The Economic Development of Iran: A Recent Survey with Projections to 1981, (New York: Praeger Publishers, 197j); H. Katonzian, The Political Economy of Modern Iran 1926-1974, (New York: New York University Press, 1981). See also articles published in specialized journals, e.g., The Middle East Journal and Tahghight Eqtesadi.

2J. Amuzegar and M. A. Fekrat, pp. 147-163.

3Firouz, Vakil, "Iran's Basic Macroeconomic Problems: A Twenty-Year Horizon", Economic Development and Cultural Change, July 1977, pp. 713-727.

${ }^{4} \mathrm{H}$. C. Wallich, "A Theory of Derived Development", in A. N. Agarwala and S. P. Singh, eds., The Economics of Underdevelopment, (New York: Oxford University Press, 19631, p. 159 .

5John M. Keynes, The General Theory of Employment, Interest and Money, (London: Macmillan, 1963), p. 114.

6M. K. Evans, Macroeconomic Activity: Theory, Forecasting, and Control, (New York: Harper and Row, 1969), p. 14.

${ }^{7}$ Paul Wonnacott, Macroeconomics (Homewood, Illinois: Richard D. Irwin, Inc., 1984), pp. 221-227.

8 M. K. Evans, pp. 17-19.

${ }^{9}$ M. K. Evans, pp. 19-21.

10 M. K. Evans, pp. 22-24.

$11_{M}$. K. Evans, pp. 24-25.

12David G. Mayes, Applications of Econometrics, (Englewood Cliffs, New Jersey: Prentice Hall International, 1981), pp. 260-272. 
13 As will be mentioned in the next chapter, this type of aggregate production function gives unsatisfactory results for developing economies such as Iran even with heroic assumptions made for constructing relevant time series. 
CHAPTER V

ESTIMATION AND EVALUATION OF THE MODEL

In this chapter we will focus our attention on the estimation and statistical properties of the model. The model in its general form consists of twelve stochastic equations with unknown parameters to be estimated from the historical time series data and subject to random error terms. In addition there are two identities. AlI the stochastic equations have been specified as linear relationships with a lag structure of a single period. Annual data in constant prices were used in all cases. Furthermore, historical simulation was performed to test the validity of the model. In general the results were quite satisfactory and indicated an overall statistical fit of the estimated model.

\section{Basic Aspects of Data Limitation}

In dealing with econometric models of developing countries, empirical studies are severely constrained by the unavailability of reliable, consistent, and detailed data over a sufficiently long period of time. The available data of most developing countries present several problems to the econometrician. First, national income accounts have not been adequately developed and they should be 
revised periodically. But these revisions not only affect the estimates but also the conclusions drawn from the models. The basic difficulty particularly arises when all figures do not undergo a revision of any comparable magnitude. Second, consistent data are available for only limited periods of time, while detailed data may not exist in some areas at all. Limited number of observation creates severe estimation barriers and makes the application of more efficient estimators impossible. Paucity of data is certainly a constraint, but it is precisely this situation that poses a challenge to the econometrician. To some extent, problems involved could be surmounted, depending on the situation, by judicious use of what is available in terms of data. Third, given the lack of adequate legitimate data, the developing countries may provide data of very low quality. Some items in the national income accounts are estimated through some mechanistic formula involving other items in those accounts rather than independently estimated. In some cases price deflators used to convert nominal values into real ones are not reliable. In other cases, unrefired data not only have their source in the questionable deflators, but also in multiple or frequently changing exchange rates. These problems may lead to constructing models with errors in the variables. When there are errors in measuring an independent variable, the fourth assumption of the Classical Linear Regression (CLR) 
model is violated, since the independent variables may not be independent any more from the disturbance term. Thus, the OLS estimator is biased even asymtotically and instrument variable method or weighted regression must be used to deal with this problem. 1

Data on the Iranian economy entails many aforementioned difficulties. Up to 1959, data was available only for some major economic variables. But statistics published by different sources were often inconsistent with one another. In this study the model is estimated over the period 1959-76, for which the information division of Plan and Budget Organization did publish during 1975-78 a set of tables under the name of "Economic Trends of Iran" with annual data for a relatively large number of variables. 2 Economic Trends of Iran was a regular publication based on a computerized data storage and retrieval system as well as a computerized printing system containing the latest economic statistics. It was basically a response to "lack of data" problem as well as to provide a comprehensive coherent and consistent set of data in one volume. Annual data in constant prices has been used in all cases.

Although, the quality and size of the data on Iranian economy had been improved in the Economic Trends of Iran, the reliability of the data is still far from satisfactory. The general unreliability of data has its source mostly in the rural sector. Several time series, such as consumption 
and investment are constructed on the basis of small samples or simplistic assumptions. Data on important items like capital stock, food consumption, unemployment, imports of food, wage rates simply are not available.

In spite of these problems, we have taken the challenge with the hope that our study equipped with relatively improved data and superior estimation techniques in comparison to the previous studies may provide some useful insights in regard to the structure and operation of the Iranian economy.

\section{Estimation Procedures}

The estimation and simulation of the model is carried out by Time Series Processor (TSP) econometric package. Equations are estimated by Ordinary Least Squares (OLS) and Two-Stage Least Squares (TSLS). To overcome the problem of autocorrelation and to obtain efficient estimates, first order serial correlation (AR1) procedure proposed by Beach and MCKinnon is used to estimate equations whose disturbances displayed first order serial correlation. ${ }^{3}$

System estimating procedures such as 3SLS and FIML estimate all the identified structural equations together as a set, instead of estimating the structural parameters of each equation separately. Their main advantage is that because they incorporate all of the available information into their estimates, they have a smaller asymptotic 
variance-covariance matrix than single equation estimators. By the same token, however, if the system is misspecified the estimates of all the structural parameters are affected, rather than, the estimates of the parameters of only one equation which may happen in the case of singleequation estimation. Furthermore, the 3SLS and FIML impose very strong degrees of freedom requirement on a system. Computation of system methods require that the number of observations must be equal or greater than the number of parameters in the model: 4,5

$\mathrm{T}>\mathrm{m}+\mathrm{n}$

where $\quad T=$ number of observations;

$m$ = number of regressors in the model;

$\mathrm{n}=$ number of equations.

Clearly, the degrees of freedom requirement demanded by system methods makes the application of these estimators impossible as far as our model is concerned.

As stated earlier system methods are very sensitive to the correct specification of the entire model. A specification error in one equation would affect the estimates of parameters in all equations of the model. The possibility of making specification errors is much higher in the smaller models since there are limited number of variables to choose from for the purpose of specification. The chances of committing specification errors are also greater in construction of models for developing countries where no 
sound and well-established theories are aviilable. Under these conditions the application of TSLS has been highly recommended. 6

Presentation of Estimated Equations variables used in the estimation are measured in 1959 constant prices, and thousanas of persons. Consistent sets of data are only available for the period of 1959-1976.

The results of the estimation of the model will be represented next, but generally speaking the statistical results are quite satisfactory considering high values of the adjusted coefficient of determination and the size of the regression coefficients relative to their standard errors. The Durbim-Watson and $h$ statistics also indicate that most regressions are relativeiy free from first order serial correlation in disturbances.

In cases where TSLS and OLS yield almost the same results, estimates of TSLS are only reported.

\section{Private Consumption Equations}

The private consumption expenditure equations reported in this section are estimated by using functional formulations suggested by Friedman, Erown, and Keynes. Iran's population had been rising rather fast at around 3.1 percent annually over our observation period. Some of the increase in consumption may therefore be attributed to rise in the population in general which can be accounted for by the 
inclusion of the population as an explanatory variable in our consumption equations.

Comparing the results of the estimation of various formulations it is reasonable to state that, the magnitudes and signs of coefficients of the equations estimated according to the Friedman's formulation are theoretically more plausible than those estimated according to Brown and Keynesian formulations. In addition to terms of $\frac{2}{R}$, t-tests and Dubin-Watson statistics, estimation results from Friedman's equations are superior to the estimation results from Brown's equations and much better than estimation results from the equations suggested by Keynsian hypothesis. The rural consumption equation estimated in terms of Brown's formulation suggests a negative relationship between the consumption and the population growth which is not a satisfactory result. In addicion the magnitude of VAA coefficients for rural consumption is too high and for urban consumption is too $1 \mathrm{cw}$.

An attempt had also been made to use per capita instead of total figures in our estimations. The result of Friedman:

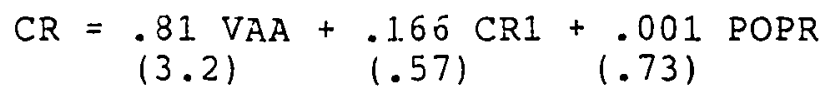

$$
\begin{aligned}
& \begin{array}{ll}
\frac{2}{\mathrm{R}}=.99 & \text { D.W. }=1.87
\end{array}
\end{aligned}
$$

$$
\begin{aligned}
\mathrm{CR}= & .4 \mathrm{VAA}+.61 \mathrm{CR} 1+\frac{.001 \text { POPR }}{(43)}(178) \\
& \text { D.W. }=1.9
\end{aligned}
$$


(3) $\mathrm{CU}=\frac{38 \mathrm{VAU}}{(3.4)}+\frac{.38 \mathrm{CU} 1}{(1.6)}+\underset{(1.8)}{.002} \mathrm{POPU}$

(OLS)

$$
\begin{array}{ll}
\frac{2}{R}=.99 & D \cdot W \cdot=1.9
\end{array}
$$

(4) $\mathrm{CU}=\underset{(144)}{.29 \mathrm{VAU}}+\underset{(137)}{.57 \mathrm{CU} 1}+\underset{(85)}{.002 \mathrm{POPU}}$

(TSIS)

$$
\text { D.W. }=1.92
$$

\section{Brown:}

$$
\begin{aligned}
& \text { (5) } \mathrm{CR}=102.6+1.1 \mathrm{VAA}+.23 \mathrm{CRI}-.007 \mathrm{POPR} \text { (OLS) } \\
& (1.7) \quad(3.4) \quad(.8) \quad(-1.6) \\
& \begin{array}{ll}
\frac{2}{\mathrm{R}}=.82 & \text { D.W. }=1.8
\end{array} \\
& \text { (6) } \mathrm{CR}=85+.52 \mathrm{VAA}+.61 \mathrm{CR} 1-.006 \mathrm{POPR} \quad \text { (TSLS) } \\
& \text { (14) (32) (23) (12) } \\
& \text { D.W. }=1.8
\end{aligned}
$$

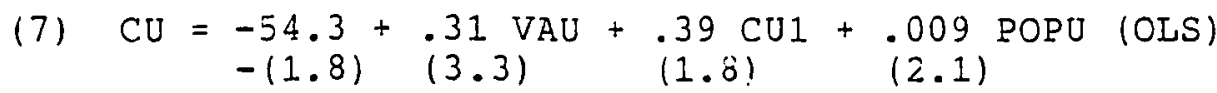

$$
\begin{aligned}
& \frac{2}{\mathrm{R}}=.99 \quad \text { D.W. }=1.95 \\
& \text { (8) } \mathrm{CU}=\frac{-48.4}{(-8.5)}+\underset{(158)}{.24} \mathrm{VAU}+\underset{(125)}{.59 \mathrm{CU} 1}+\underset{(65)}{.008} \mathrm{POPU} \text { (TSLS) } \\
& \text { D.W. }=1.95
\end{aligned}
$$

Keynes:

$$
\begin{aligned}
& \text { (9) } \mathrm{CR}=\frac{119.6}{(2.4)}+\frac{1.27}{(5.3)} \mathrm{VAA}-\underset{(-1.7)}{.01 \mathrm{POPR}} \\
& \begin{array}{ll}
\frac{2}{\mathrm{R}}=.9 & \text { D.W. }=.9
\end{array}
\end{aligned}
$$


(10)

$$
C R=\frac{185.4}{(11.2)}+\frac{1.49}{(24.7)} \mathrm{VAA}-\underset{(-9.4)}{.01} \mathrm{POPR}
$$

$$
\text { D.W. }=1.76
$$

$$
\begin{aligned}
& \mathrm{CU}=-73.8+.47 \mathrm{VAU}+.01 \mathrm{POPU} \\
& (-2.4) \quad(11.5) \quad(3.4) \\
& \frac{2}{\mathrm{R}}=.99 \\
& \text { D.W. }=1.28
\end{aligned}
$$

$$
\begin{aligned}
\mathrm{CU}= & .79 .4+ \\
(-49) & .465 \mathrm{VAU}+ \\
& .015 \mathrm{POPU} \\
& (71) \\
& \text { D.W. }=1.77
\end{aligned}
$$

An attempt had also been made to use per capita instead of total figures in our estimations. The result of estimations, however, were not satisfactory at all and we chose not to present them here. All of the estimated coefficients except coefficients of the urban consumption equations suggested by the Friedman were statistically insignificant. Urban consumption equation estimated according to Friedman's formulation yielded:

$$
\begin{aligned}
& \mathrm{CU}=.21 \mathrm{VAUP}+.73 \mathrm{CUP} 1 \\
& \text { (3) } \quad(6.2) \\
& \begin{array}{ll}
\frac{2}{\mathrm{R}}=.99 & \mathrm{D} \cdot \mathrm{W} \cdot=1.9
\end{array}
\end{aligned}
$$


Short-run and Long-run Marginal Propensities to Consume

Both Friedman's and Brown's formulations distinguish between short-run and long-run marginal propensity to consume. Given the estimated coefficients of consumption equations and the rate of growth of consumption for rural and urban areas, the long-run marginal propensities to consume can be calculated as follows:

Friedman:

Long-run marginal propensity to consume $=\frac{b^{\prime}(1+g)}{(1+g)-d^{\prime}}$

where

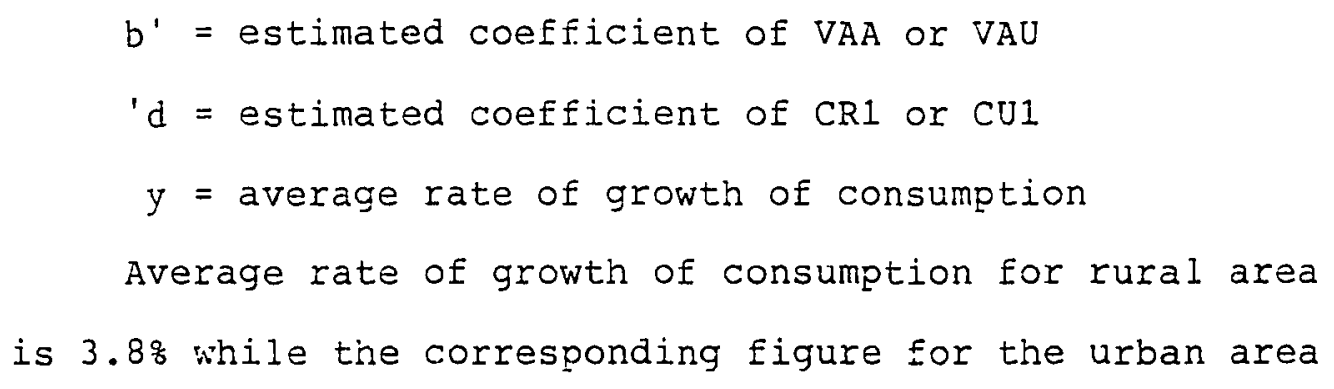

Rural Area

$$
\begin{aligned}
& \text { Short-run MPC }=.4 \\
& \text { Long-run MPC }=\frac{.4(1.038)}{1.038-.61}=.97
\end{aligned}
$$

Urban Area

Short-run MPC $=.29$ 


$$
\begin{aligned}
& \text { Long-run MPC }=\frac{.29(1.11)}{1.11-.57}=.6 \\
& \text { Long-run MPC using per capita Eigures } \\
& \text { for estimation }=\frac{.21(1.11)}{1.11-.7 j}=.61
\end{aligned}
$$

Brown:

Rural Area

$$
\begin{aligned}
& \text { Short-run MPC }=.52 \\
& \text { Long-run MPC }=\frac{.52(1.038)}{1.038^{-.61}}=1.26
\end{aligned}
$$

Urban Area

$$
\begin{aligned}
& \text { Short-run MPC }=.24 \\
& \text { Long-run MPC }=\frac{.24(1.11)}{1.11-.59}=.5
\end{aligned}
$$

Notice that using Brown's formulation we get an estimate of long-run marginal propensity to consume for rural area which is too high. On the other hand the estimate of long-run marginal propensity to consume for urban area is too low. Notice further that the total and per capita formulations suggested by Friedman almost yield the same longrun marginal propensity to consume.

The Friedman hypothesis postulates that long-run marginal propensity to consume is equal to average propensity to consume. In the case of Iran average propensity to consume for rural areas ranges from 1.2 at the beginning of the estimations period to 11 at the end of the estimation 
period. Average propensity to consume for urban areas had been stable around .61. Our estimate shows that LMPC of the urban area is almost equal to the APC of the urban area. IMPC and APC of the rural area differ from each other but they are very close. But notice that the value of LMPC depends on the value of $g$, the rate of growth of consumption, and is rather sensitive to it. In other words the lower the rate of growth of consumption, the higher will be the estimate of LMPC.

Government Consumption Expenditures

$$
\begin{aligned}
C G= & -53.4+.89 \mathrm{CG} 1+\underset{(3.4)}{(-2.5)}(10) \\
\frac{2}{\mathrm{R}}= & .98 \\
& \text { D.W. }=2
\end{aligned}
$$

$$
\begin{aligned}
C G= & 210.7+.67 \mathrm{CG} 1+\underset{(2.4)}{(-.3)}(2.2) \\
\frac{2}{\mathrm{~K}}= & .98 \\
\text { D.W. }= & 1.8
\end{aligned}
$$

\section{Foreign Trade Relations}

The estimated equations for imports of consumer goods (IMC), imports of intermediate and capital goods (IMK), and exports of non-oil commodities (EXNO) are shown below. The results are self explanatory and there is no need for further elaborations. 
Imports of Consumer Goods

(1) $\mathrm{IMC}=-20.6+.12 \mathrm{GDP}+.46$ IMC1
(OLS)

$$
\begin{aligned}
\frac{2}{R}= & .94 \\
& \text { D.W. }=1.6
\end{aligned}
$$

(2) IMC $=\frac{-22.1}{(-22)}+\underset{(2.8)}{0.6} \mathrm{GDP}+\underset{(4.3)}{.73} \mathrm{IMCI}$

(TSLS)

$$
\begin{aligned}
\frac{2}{R}= & .96 \\
& D . W .=1.7
\end{aligned}
$$

Imports of Intermediate and Capital Goods

(3) IMK $=-3.8+.88$ INVU -.007 VAU1

(OLS)

$$
\begin{aligned}
\frac{2}{\mathrm{R}}= & .99 \\
& . \mathrm{D} \cdot \mathrm{W} .=1.5
\end{aligned}
$$

(4) IMK $=\frac{-37.4}{(-18)}+\underset{(10)}{.25}$ INVU $+\underset{(22)}{.31 \text { VAUI }}$

(TSLS)

$$
\text { D.W. }=1.9
$$

Exports of Non-oil Commodities

(5) EXNO $=-20.9+.34$ VAA

$$
(-6.9) \quad(13.5)
$$

(OIS)

$$
\begin{aligned}
& \frac{2}{R}=.92 \\
& \text { D.W. }=1.1
\end{aligned}
$$

(6) EXNO $=-21.7+.35 \mathrm{VAA}$

$$
\begin{aligned}
& (-84) \quad(167) \\
& \text { D.W. }=1.9
\end{aligned}
$$

(TSLS) 


\section{Production Equations}

Supply functions in our model is subdivided into two categories: Output in urban sector and output in agriculture sector.

The traditional "neo-classical" production function concentrates on two major economic factors in production, labor and capital. As we did mention earlier a complete and satisfactory data of capical stock for urban and agriculture sectors are not available for the Iranian economy. The values of investments made in urban and agriculture sectors are however available for the period 1959-1976. The values for capital stock are determined in the following way: First a capital-output ratio equivalent to 4 was assumed for the year 1959.7 On the basis of capital-output ratio and data for value added in the urban and agriculture sectors the capital stock was estimated for 1959. Then the value of capital stock for the later years were obtained by adding the annual net additions to the capital stock, i.e., investment less depreciation. 8 The estimation of the linear, general Cobb-Douglas production functions and Cobb-Douglas production function assuming constant returns to scale $\left(a_{1}+a_{2}=1\right)$ yielded the following results for the urban sector:

Linear Production Function

$$
\begin{aligned}
& \text { (1) } \mathrm{VAU}=\frac{-410.4}{(-3)}+\underset{(5)}{.66} \mathrm{kU1}-\underset{(-2)}{.06 \mathrm{LU}} \quad \frac{2}{\mathrm{R}}=.99 \\
& \text { D.W. }=1.2
\end{aligned}
$$


Cobb-Douglas Production Function

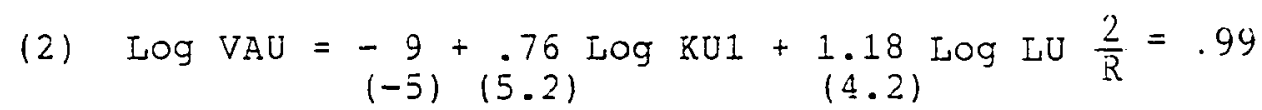

D.W. $=1.6$

or in non-linear form

(3) $\mathrm{VAU}=.1 \mathrm{E}-8 \mathrm{KU1} \cdot 76 \mathrm{LU} 1.18$

Cobb-Douglas with constant returns to scale (4) $\log (\mathrm{VAU} / \mathrm{KU} 1)=\frac{-.32}{(-.7)}+.22 \log \underset{(.9)}{(\mathrm{LU} / \mathrm{KU} 1)} \frac{2}{\mathrm{R}}=.98$ D.W. $=.97$

or in non-linear form

(5) $\mathrm{VAU}=.48 \mathrm{KU} 1.78 \mathrm{LU} \cdot 22$

where

KU1 = capital stock in urban sector lagged one year

IU = labor employed in urban sector

Although the results obtained for linear production function and Cobb-Douglas production function are statistically significant, the value of efficiency parameter in the case of Cobb-Douglas production function is very close to zero which is not theoretically plausible. The estimates of the parameters of production function with constant returns to scale are not statistically significant but the values obtained for capital and labor elasticities are plausible.

Estimation of the linear supply functions according to the specifications suggested in Chapter IV yielded the following results: 
(5)

$$
\begin{aligned}
& \text { VAU }=\frac{-8.3+V A U 1}{(-1)}+\frac{.44}{(7.9)} \text { INVU1 }+\underset{(1)}{.04} \text { GIU } \\
& \frac{2}{\mathrm{R}}=.87 \\
& \mathrm{D.W}=1.3
\end{aligned}
$$

(TSLS)

$$
\begin{aligned}
& \text { VAU }=\frac{-7.5}{(-8)}+\text { VAU1 }+\underset{(7.6)}{.44 \text { INVU1 }}+\underset{(9)}{.04 \text { GLU }} \\
& \frac{2}{\mathrm{~K}}=.95
\end{aligned}
$$

The results obtained from the TSLS estimation of this linear function are statistically as well as theoretically quite satisfactory and as we shall see in the next section the historical simulation of the equation (6) yields acceptable predictions.

Estimation of the linear supply function represented by equations (8) and (9) gave the following results for the agriculture sector:

$$
\begin{aligned}
& \mathrm{VAA}=.4 .21+1.04 \mathrm{VAA}+.32 \mathrm{INVA}+.03 \mathrm{GLA}+.005 \mathrm{GLAND} \\
& \begin{array}{llll}
(-.47) \quad(11) \quad(1.5) \quad(1.3) \quad \text { (1.6) (OLS) } & \text { (OL) }
\end{array} \\
& \begin{array}{ll}
\frac{2}{\mathrm{R}}=.97 & \text { D.W. }=1.8
\end{array}
\end{aligned}
$$

(9) $\mathrm{VAA}=\frac{-9.2+\mathrm{VAA} 1+.67 \mathrm{INVA}+.1 \mathrm{GLA}+\underset{(.72)}{(7.8)}+.05 \mathrm{GLAND}}{(2.8)}$ (TSLS)

D.W. $=2.1$

Two points should be mentioned in regard to the estimated supply functions of the agriculture sector. First, the TSLS results are superior to the results obtained from 
OLS estimator in terms of t-statistics and D.W. statistic. Second, the coefficient of GLA is positive in both equations. This may imply that the marginal productivity of labor in agriculture sector is not equal to zero as assumed in the dualistic models of W.A. Lewis and Fei and Ranis. Value added in oil sector mainly depends on exports of oil. The results of estimation are given in equation (10). $(10)$

$$
\begin{array}{ll}
\text { VAO }=\begin{array}{ll}
6.8 \\
(2.2)
\end{array}+.99 \text { EXO } & \text { (TSLS) } \\
\frac{2}{\mathrm{R}}=.99 & \text { D.W. }=2.1
\end{array}
$$

Employment and Indirect Taxes

$$
\begin{aligned}
& \text { (1) } \quad \text { LA }=\underset{(31)}{3945.7} \underset{(-2.8)}{.98} \text { INVU1 }-\underset{(-1.6)}{5.55} \text { INVA } \\
& \begin{array}{ll}
\frac{2}{R}=.36 & D . W .=2.3
\end{array} \\
& \text { (2) } \mathrm{GI}_{1} \mathrm{U}=160.1 \div .6 \text { INIVU1 } \text { (TSLS) } \\
& \text { (2) (1.8) } \\
& \begin{array}{ll}
\frac{2}{\mathrm{R}}=.79 & \mathrm{D} . \mathrm{W} .=2.3
\end{array}
\end{aligned}
$$

and since GLU = LU - LU1

then $\quad \mathrm{LU}=160.1+\mathrm{LU1}+.6$ INVU1

(3) $\mathrm{NIT}=26.3+.05 \mathrm{IM}$ (TSLS)

(3.5) (2)

$$
\begin{array}{ll}
\frac{2}{R}=.86 \quad \text { D.W. }-1.9
\end{array}
$$


(4) $\mathrm{NIT}=25.9+.05 \mathrm{IM}$

(3) (2)

$$
\frac{2}{R}=.85 \quad \text { D.W. }=1.7
$$

The results obtained for both sectors seems to be satisfactory. The negative sign of investments made in agriculture sector indicates the adverse effect of inappropriate and sometimes disastrous agricultural policy of the government over the estimation period. In the period 196378 while traditional agriculture sector was starving for funds, nearly all government and private credit were channeled into the modern and highly capital intensive farm corporations and agri-businesses. The combination of this modernist approach to the agriculture and urban industrial expansion led to poverty and unemployment among the peasantry and high rate of migration to towns and cities. 9

The coefficient of INVU1. in (2), indicates that on the average, one billion rials (\$14.2 million) of investment creates 660 jobs in the urban sector. This could mean that on average $\$ 21,000$ worth of investment had to be made in order to employ one more member of the labor force. There are two general explanations for this low labor absorption of new investments. In the first place, government by supplying cheap credit to the private sector encouraged the use of the capital-intensive methods and itself did the 
same in its own large-scale investment projects. In the second place, the limited administrative as well as skilled labor lead to underutilization of capacity which in turn resulted in the employment of even fewer ordinary workers than would other wise be possible.

\section{Historical Simulation of the Model}

In this section we discuss the simultaneous equation simulation and its use in evaluation and validation of our econometric model. If time series begin in $\mathrm{T}_{1}$ and end in $\mathrm{T}_{\mathrm{N}}$, then historical simulation begins in year $\mathrm{T}_{1}$ and runs forward until year $\mathrm{T}_{\mathrm{N}}$. Historical or actual values of exogenous variables and initial actual values of endogenous variables as initial conditions are used to determine the values of endogenous variables for the period $\mathrm{T}_{2}$ $\mathrm{T}_{\mathrm{N}}$ - A comparison of the actual values with simulated series for each endogenous variable then can provide a valuable test of the rodel. In the case of a single equation regression, there exists a set of statistics such as $R_{2}$, and t-tests which can be used to make judgment about the goodness of fit of the equation and its estimated coefficients. The same considerations also apply to a simultaneous system of equations. Yet the fact is that the model as a whole may have a more complicated and richer dynamic structure than that of any one of the individual equation of which it is composed. Thus even if all the individual 
equations have a very high goodness of fit and statistically significant coefficients, we have still no guarantee that the model as a whole when simulated, will reproduce the results which are close to the historical data. 10

There are two basic ways of measuring of how closely individual endogenous variables track their corresponding actual time series when the model is simulated.

(a) Root-Mean-Square Error (RMSE). The RMSE simulation error for the variable $\mathrm{Y}_{\mathrm{t}}$ is defined as follows:

$$
\operatorname{RMSE}=\sqrt{\frac{1}{\bar{T}} \sum_{t=1}^{T}\left(Y_{t}^{S}-Y_{t}^{a}\right)^{2}}
$$

where

$$
\begin{aligned}
& Y_{t}^{S}=\text { the simulated value of } Y_{t} \\
& Y_{t}^{a}=\text { the actual value of } Y_{t} \\
& T=\text { the number of periods in the simulation. } \\
& \text { The RMSE is thus a measure of the deviation of the }
\end{aligned}
$$
simulated variable from its actual time path. The size of this error should be evaluated by comparing it with the mean of the variable in question.

(b) Theil's inequality statistic (U). It is given by the following equation:

$$
U=\frac{\sqrt{\sum\left(P_{i}-A_{i}\right)^{2} / N}}{\sum A_{i}^{2} / N}
$$

where 
$\mathrm{P}_{\mathrm{i}}=$ predicted change in the dependent variable

$A_{i}=$ Actual change in the dependent variable

$\mathrm{N}=$ Number of periods in the simulation

The closer $U$ is to zero the more accurate forecasts would be obtained.

Low simulation errors are only one dasirable measure of simulation fit. It is also important to see that if the model simulates closely the "turning points" in the actual time series data.

The simulation result of the model are shown graphically in Figures 1 to 12 in which the actual and simulated series for each endogenous variable are plotted on the same set of axes. The equations used in the hisiorical simulation of the model are listed in Table VI. The numerical values of RMSE and $U$ are shown in Table $V$ along with the mean value of each variable.

Despite the simplicity of the model, its simulation performance is reasonably good, RMSE values relative to the corresponding mean values of dependent variables are quite small and Theil's inequality statistic is very close to zero in all cases. Furthermore model simulates turning points in historical time series quite well. 
TABLE V

RESULTS OF HISTORICAL SIMULATION OF THE MODEL

$\begin{array}{lrrrrrrrrrrrrr} & \text { VAA } & \text { VAU } & \text { VAO } & \text { NIT } & \text { CR } & \text { CU } & \text { CG } & \text { IMC } & \text { IMK } & \text { LA } & \text { LU } & \text { EXNO } \\ \text { RMSE } & 3.4 & 18 & 2.4 & 5 & 7.5 & 22 & 18 & 6.4 & 13 & 55 & 130 & 2 \\ \text { Mean of } & 118 & 425 & 120 & 34 & 138 & 286 & 135 & 47 & 117 & 36.97 & 4254 & 20 \\ \text { Variable } & & & & & & & & & & & \\ \text { U U } & .01 & .06 & .1 & .08 & .02 & .03 & .05 & .1 & .04 & .0 \% & .01 & .05\end{array}$


TABLE VI

THE MODEL AND ITS ESTIMATED STRUCTURAL EQUATIONS

1) GVAU $=\frac{-7.5}{(-8)}+\frac{.44 \text { INVU1 }}{(7.6)}+\frac{.04 \text { GLU }}{(9)}$

$\frac{2}{R}=.95 \quad$ D.W. -1.8

and since GVAU = VAU - VAU1

then $\quad$ VAU $=-7.5+$ VAU1 +.44 INVU1 $+.04 \mathrm{GLU}$

2) VAA $=-9.2+$ VAAI +.67 INVA +.1 GLA + .05 GLAND $\begin{array}{llll}(.72)(7.8)(2.8) & (7.1) & (2.7)\end{array}$

$\frac{2}{R}=.97 \quad$ D.W. $=2.1 \quad \mathrm{n}=.23$

3) $\mathrm{VAO}=\frac{6.8}{(2.2)}+.99 \mathrm{EXO}$

$\begin{array}{ll}\frac{2}{R}=.99 & \text { D.W. }=1.95\end{array}$

4) $\mathrm{CU}=.29 \mathrm{VAU}+.57 \mathrm{CU} 1+.002 \mathrm{POPR}$

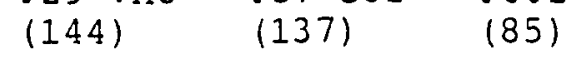

$\frac{2}{\mathrm{~K}}=.99 \quad$ D.W. $=1.92 \quad \mathrm{~h}=.16$

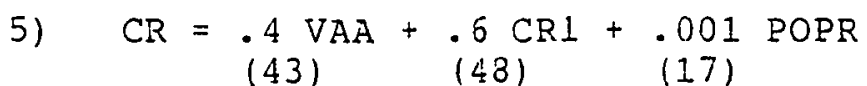
$\frac{2}{R}=.99$
D.W. $=1.9$
$h=.2$

6) $\mathrm{CG}=\frac{-53.4}{(-2.5)}+\underset{(10)}{.89} \mathrm{CGI}+\underset{(3.4)}{2.6 \mathrm{NIT}}$
$\frac{2}{\mathrm{~K}}=.98$
D.W. $=2.1$
$h=-.2$ 
TABLE VI (continued)

7) IMC $=-22.1+.06 \mathrm{GDP}+.73$ IMCI $\begin{array}{lll}(-2.2) & (2.8) \quad(4.3)\end{array}$
$\frac{2}{\mathrm{R}}=.96$
D.W. $=1.7$
$h=.6$

8) IMK $=-37.4+.25$ INVU +.3 VAUI $\begin{array}{lll}(-18) & (10) \quad(22)\end{array}$
$\frac{2}{R}=.99$
D.W. $=1.9$

9) EXNO $=\frac{-21.7}{(-84)}+\frac{.35}{(167)}$ VAA
$\frac{2}{\mathrm{R}}=.92$
D.W. $=1.9$

10) $\mathrm{GLU}=160.1+.6$ INVU1

(2) (1.8)
$\frac{2}{\mathrm{R}}=.79$
D. W. $=2.3$

and since

$$
\text { GLU }=\text { LU }- \text { LUI }
$$

then

$$
\text { IU }=160.1+\text { LU } 1+.6 \text { INVU1 }
$$

(11) LA $=3945.7-.93$ INVU1 -5.55 INVA

$$
\begin{array}{ll}
\frac{2}{R}=.80 & \text { D.W. }=2.1
\end{array}
$$

(12) $\mathrm{NIT}=\underset{(3.5)}{26.3}+\underset{(2)}{.05} \mathrm{IM}$

$$
\begin{array}{ll}
\frac{2}{\mathrm{R}}=.86 & \text { D.W. }=1.9
\end{array}
$$


List of Variables and Identities

\section{Endogenous}

(1) GVAU

(2) VAA

(3) VAO

(4) $\mathrm{CU}$

(5) $\mathrm{CR}$

(6) CG

(7) IMC

(8) IMK

(9) EXNO

(10) NIT

(11) $\mathrm{GLU}=\mathrm{LU}-\mathrm{LU} 1$

(12) IA

\section{Identities}

(1) $\mathrm{VAU}=$ GVAU + VAUL

(2) $\mathrm{GDP}=\mathrm{VAA}+\mathrm{VAU}+\mathrm{VAO}$

(3) $\mathrm{EX}=\mathrm{EXO}+\mathrm{EXNO}$

(4) $I M=I M C+I M K$

(5) $\mathrm{LU}=\mathrm{GLU}+\mathrm{LU}$. $\underline{\text { Predetermined }}$

(1) INVU1

(2) VAU1

(3) VAAI

(4) INVA

(5) GLA

(6) GLAND

(7) $\mathrm{EXO}$

(3) CU1

(9) POPU

(10) LUI

(11) CRI

(12) POPR

(13) CG1

(14) IMC1

(15) INVU 


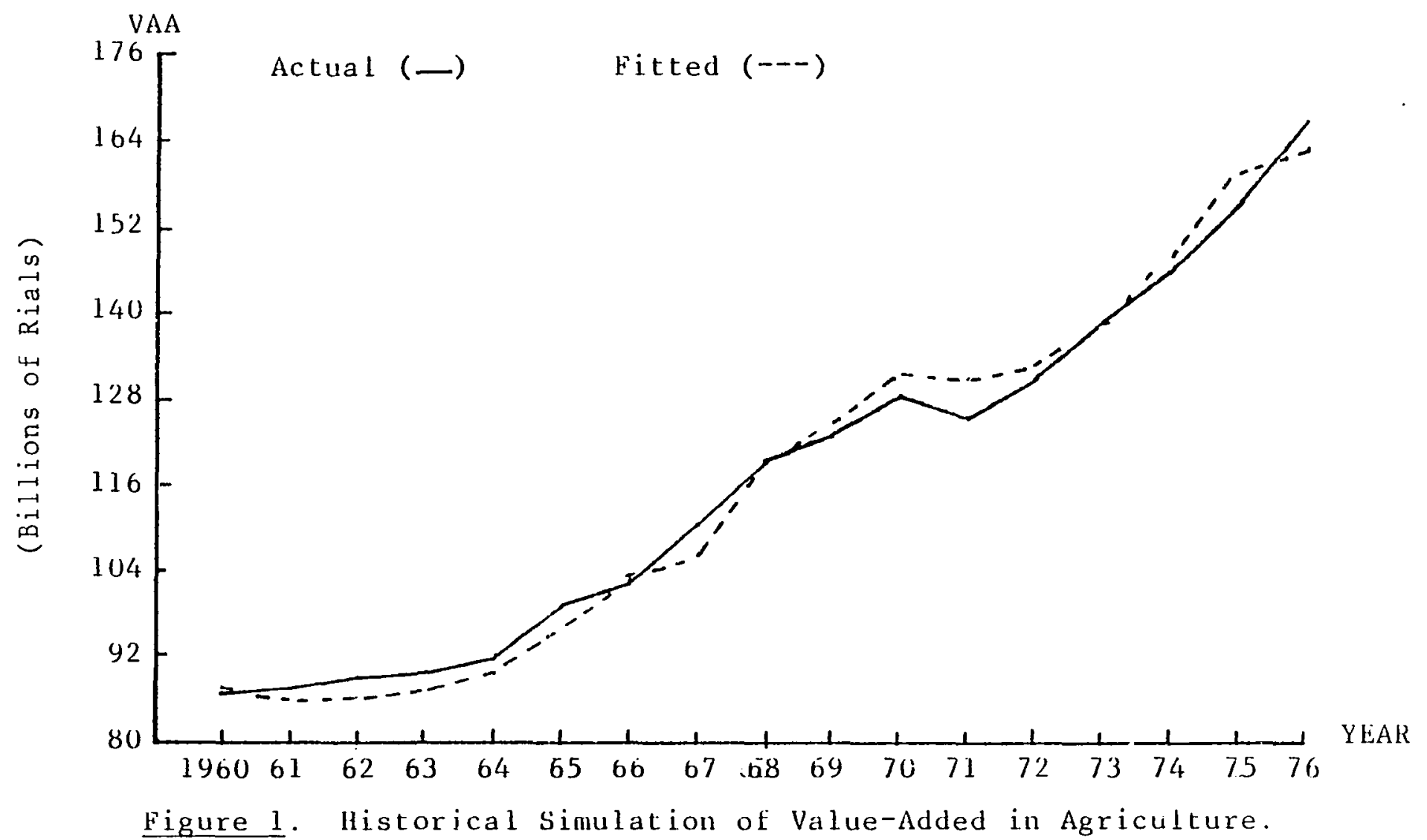




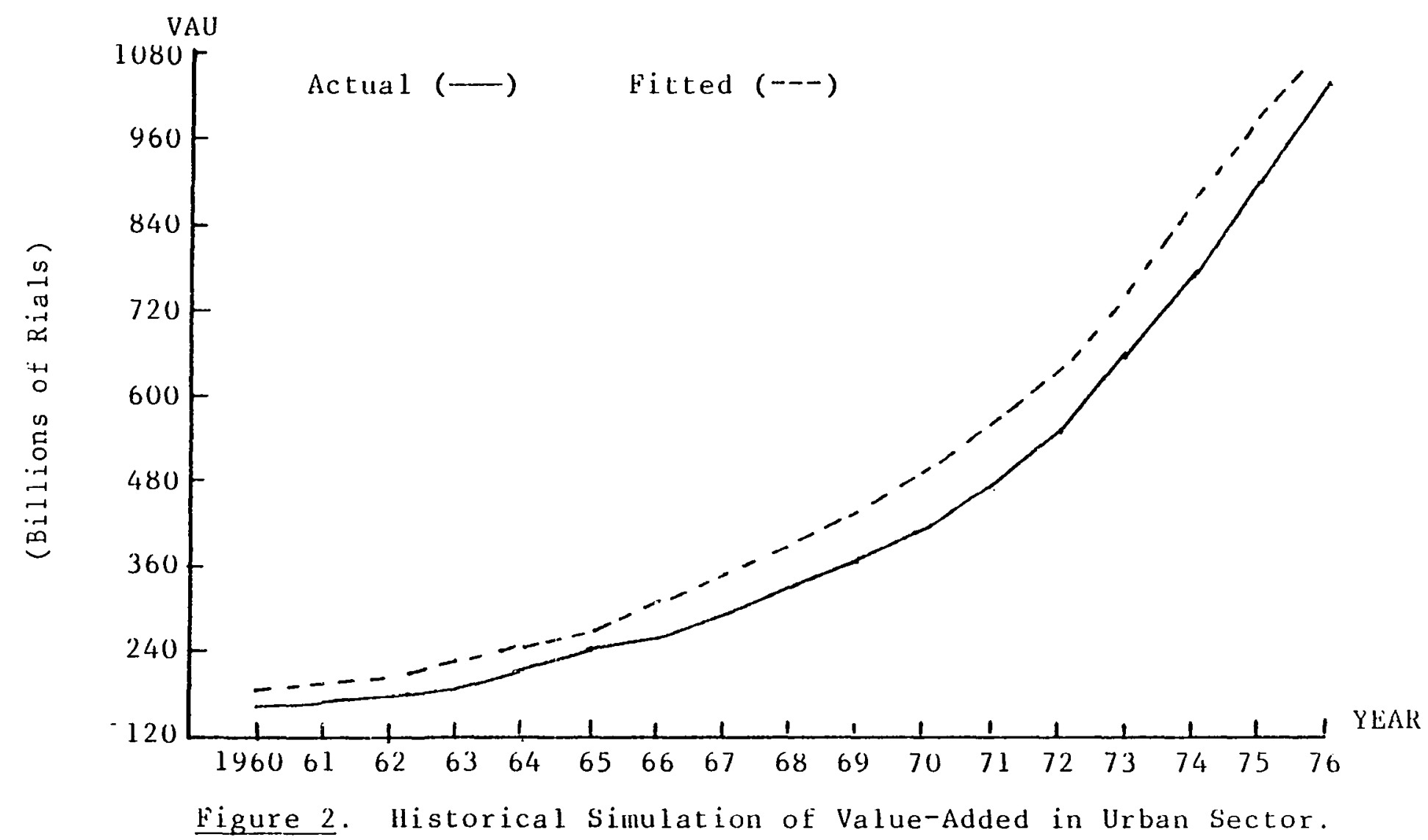




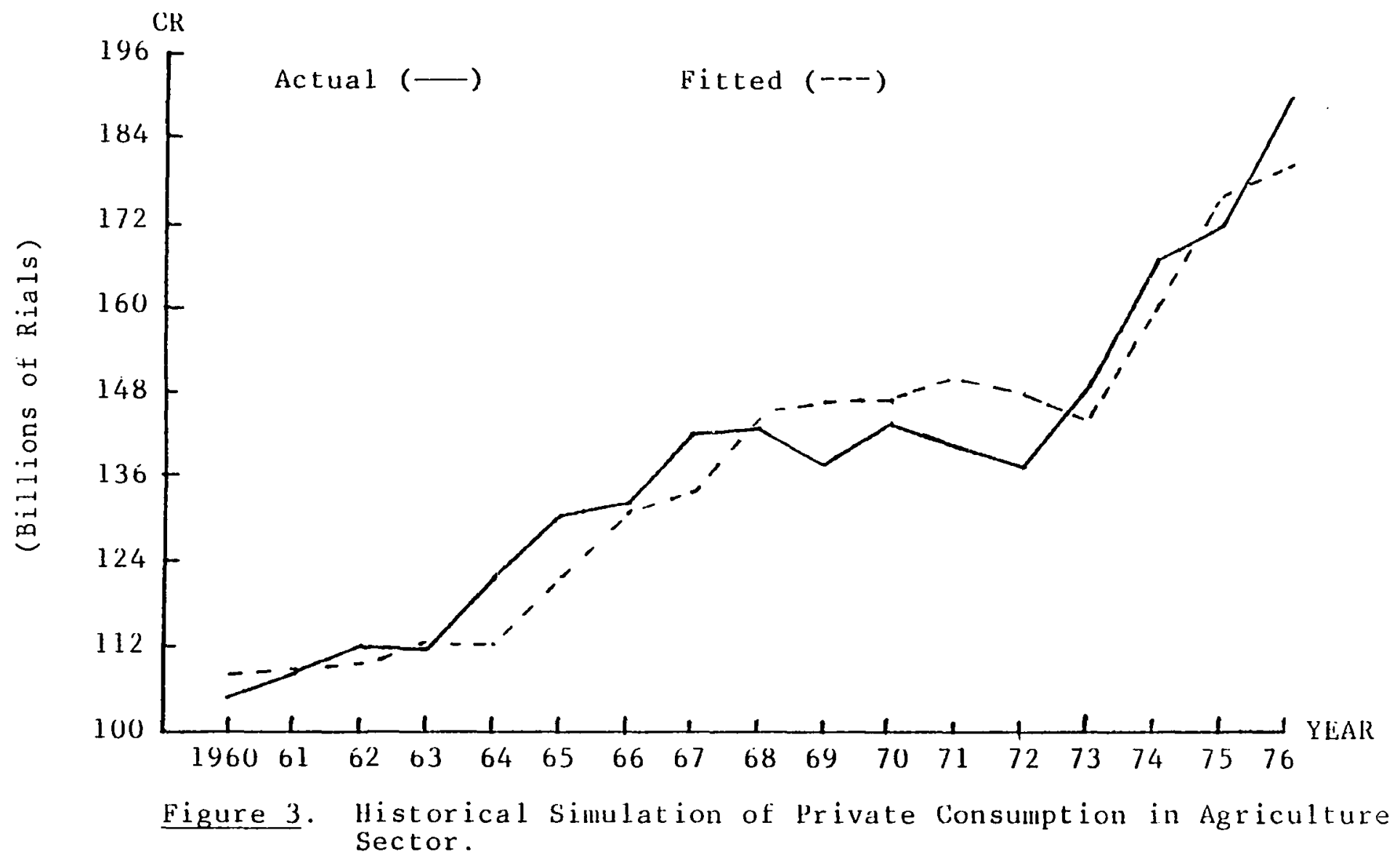




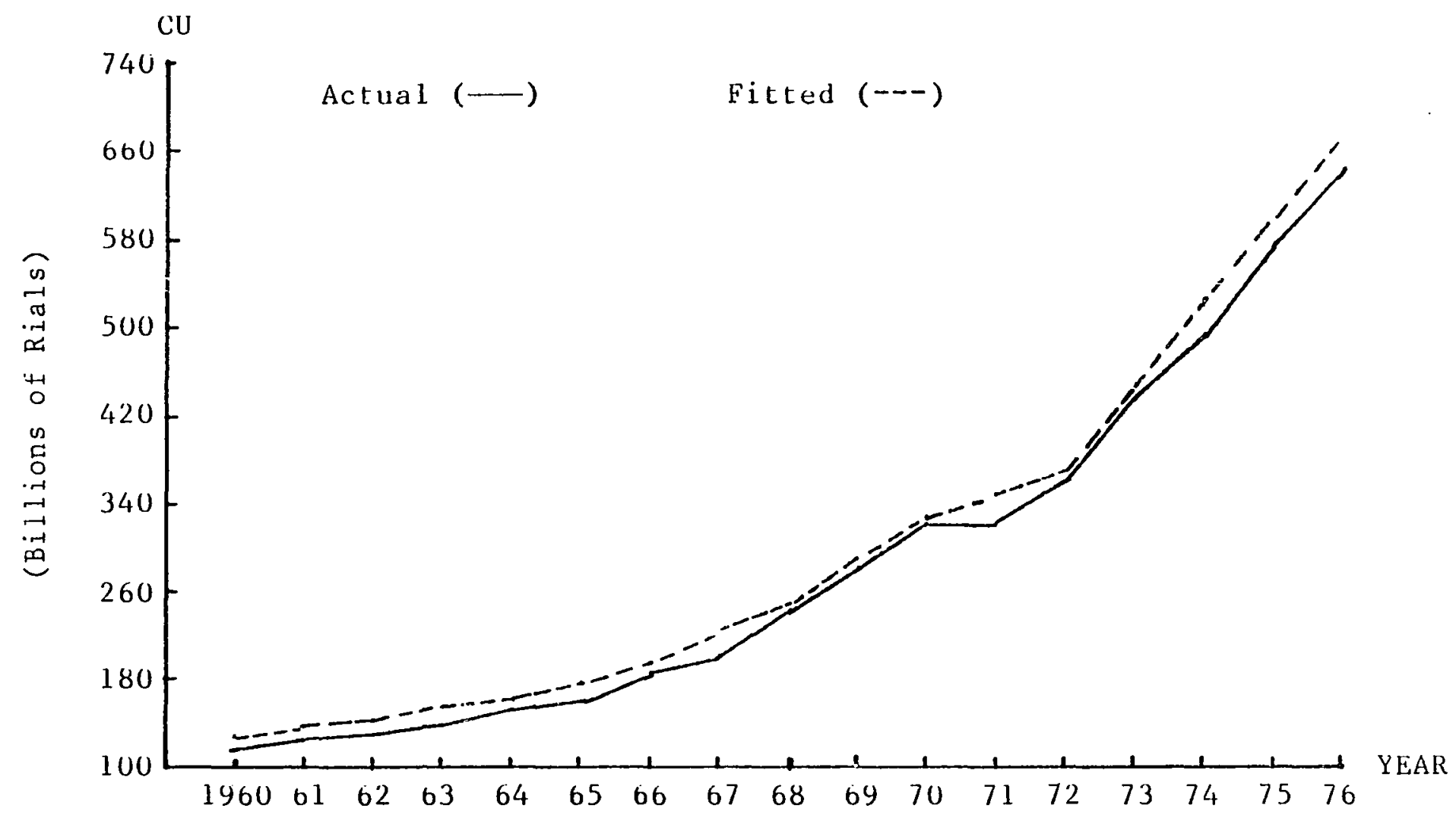

Eigure 4. Historical Simulation of Private Consumption in Urban Sector. 


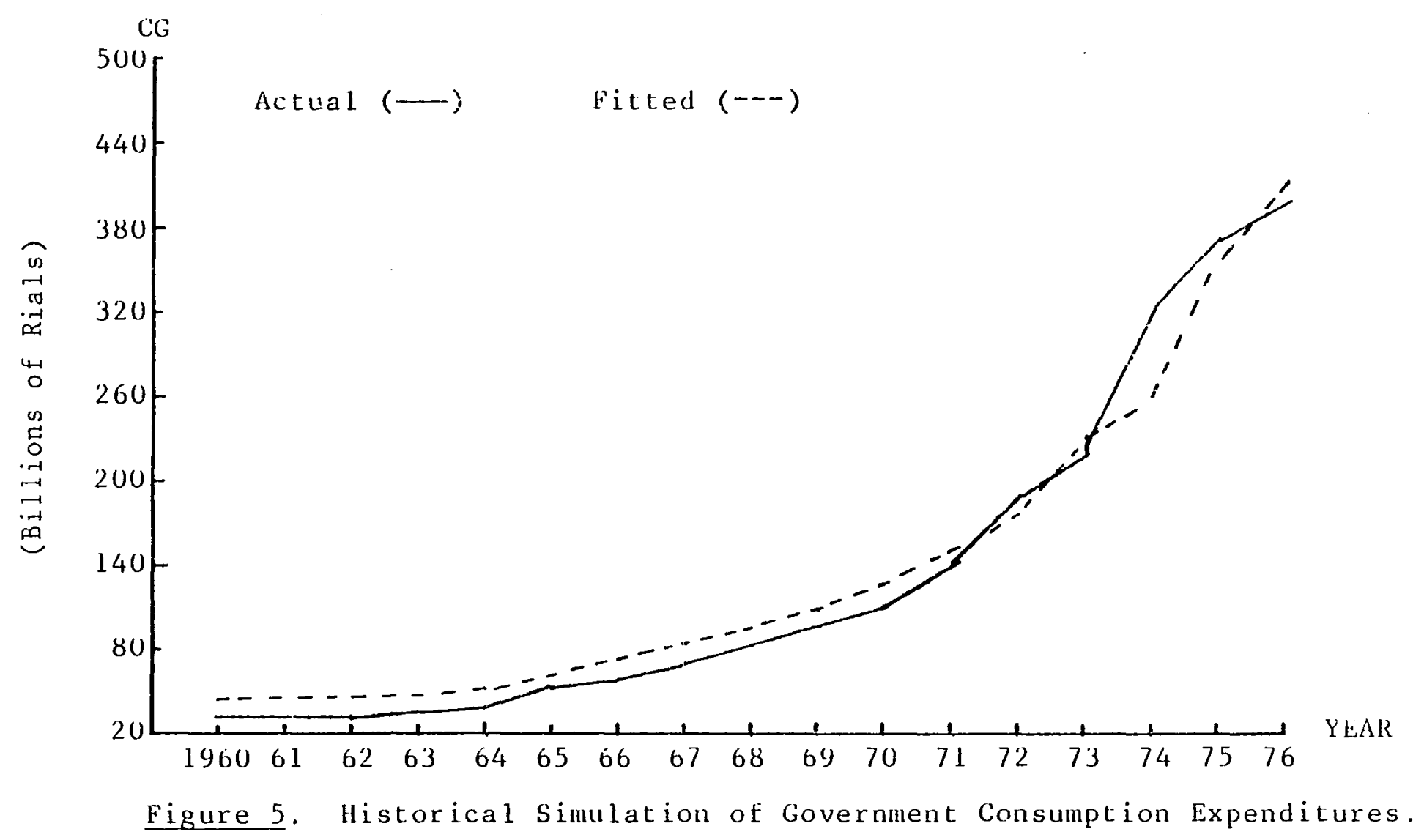




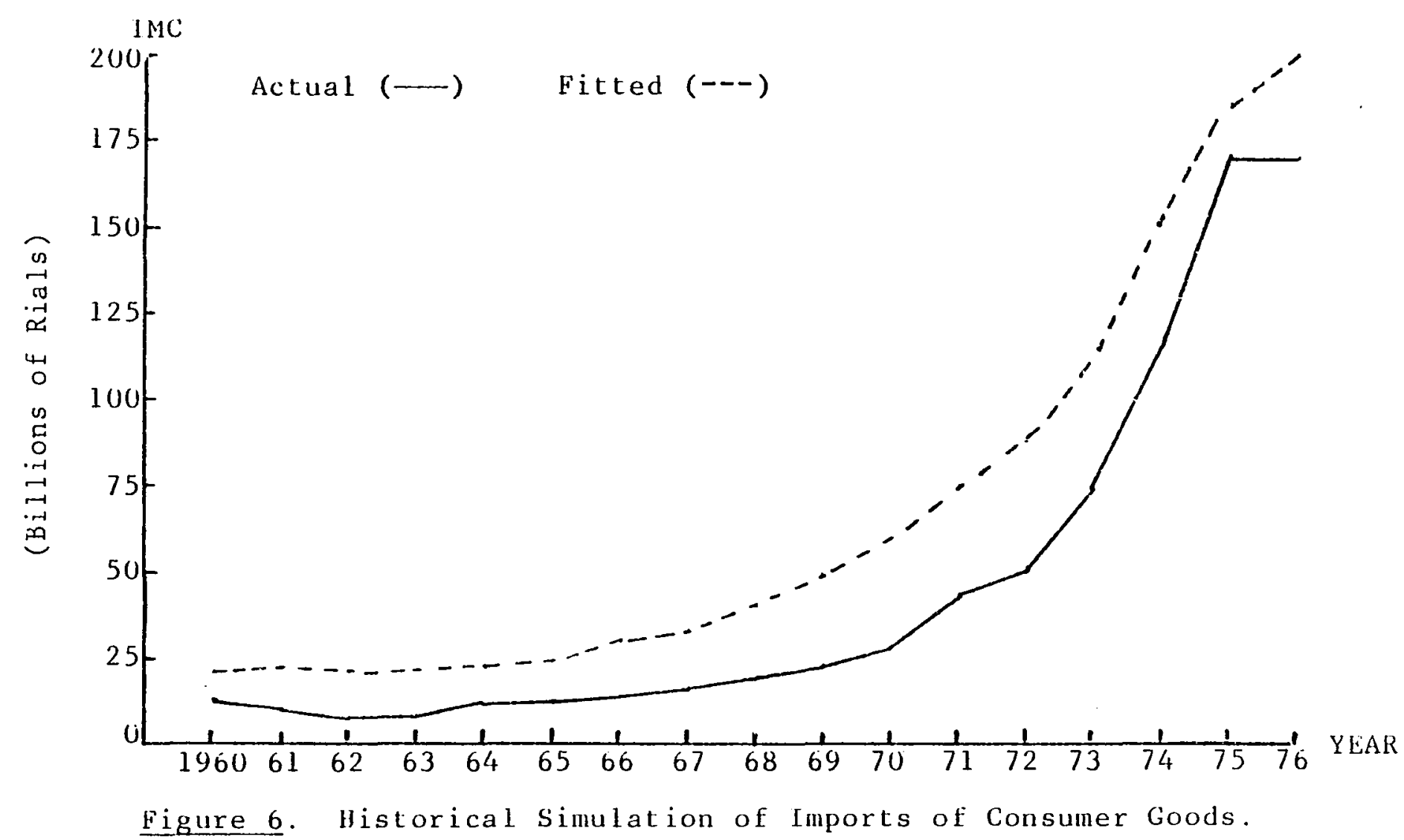




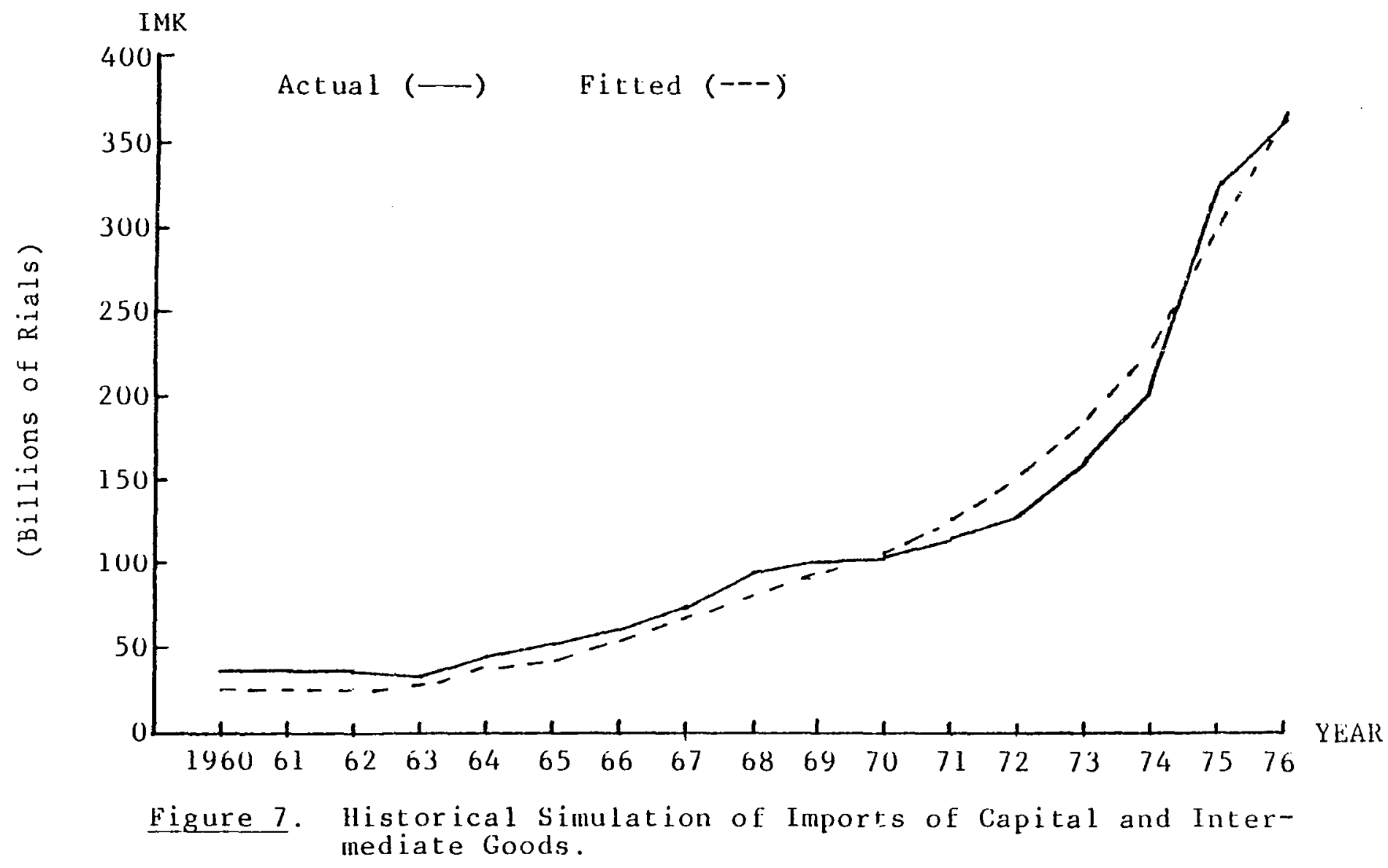




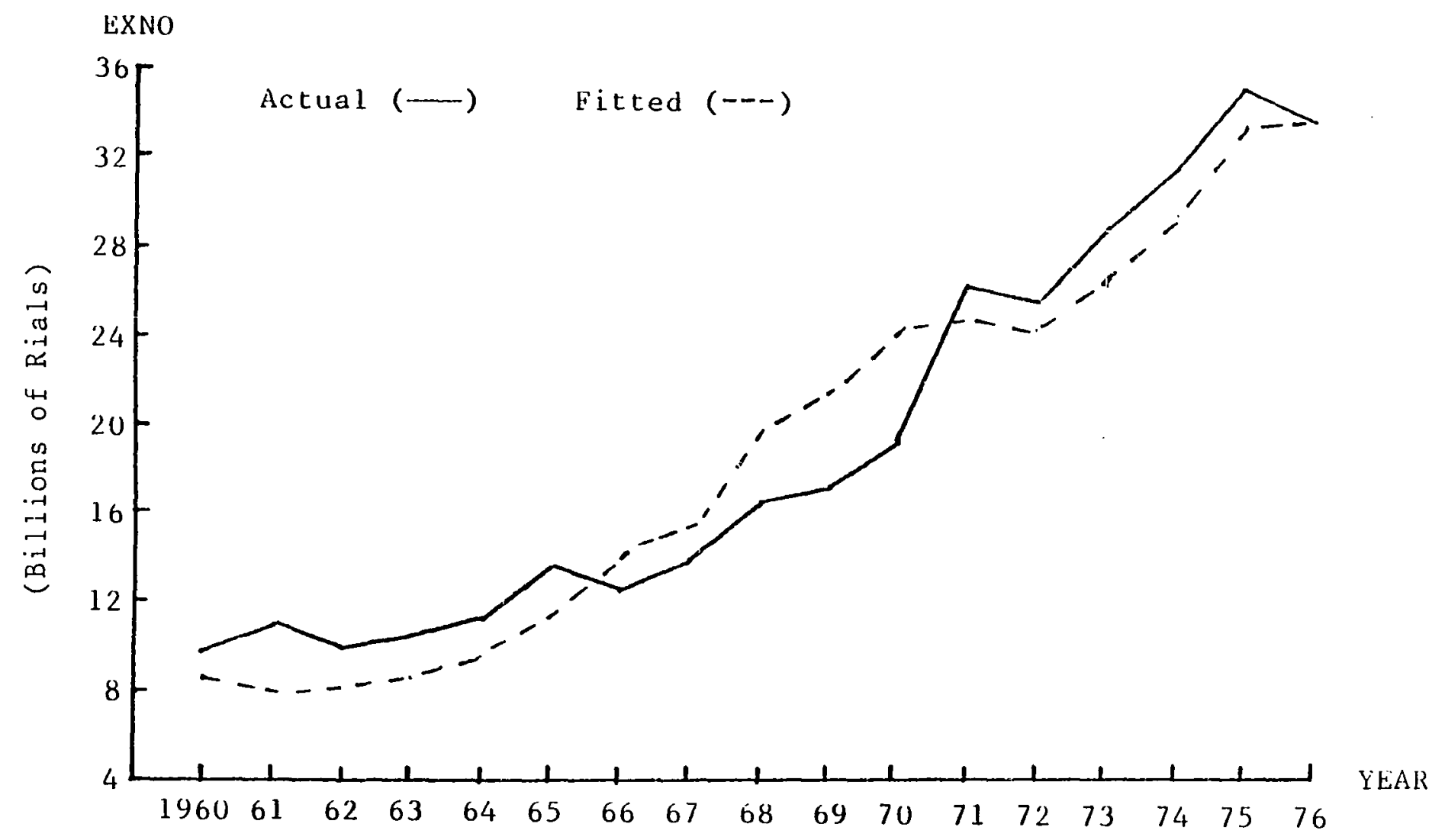

Figure 8. Historical Simulation of Non-0ilexports. 


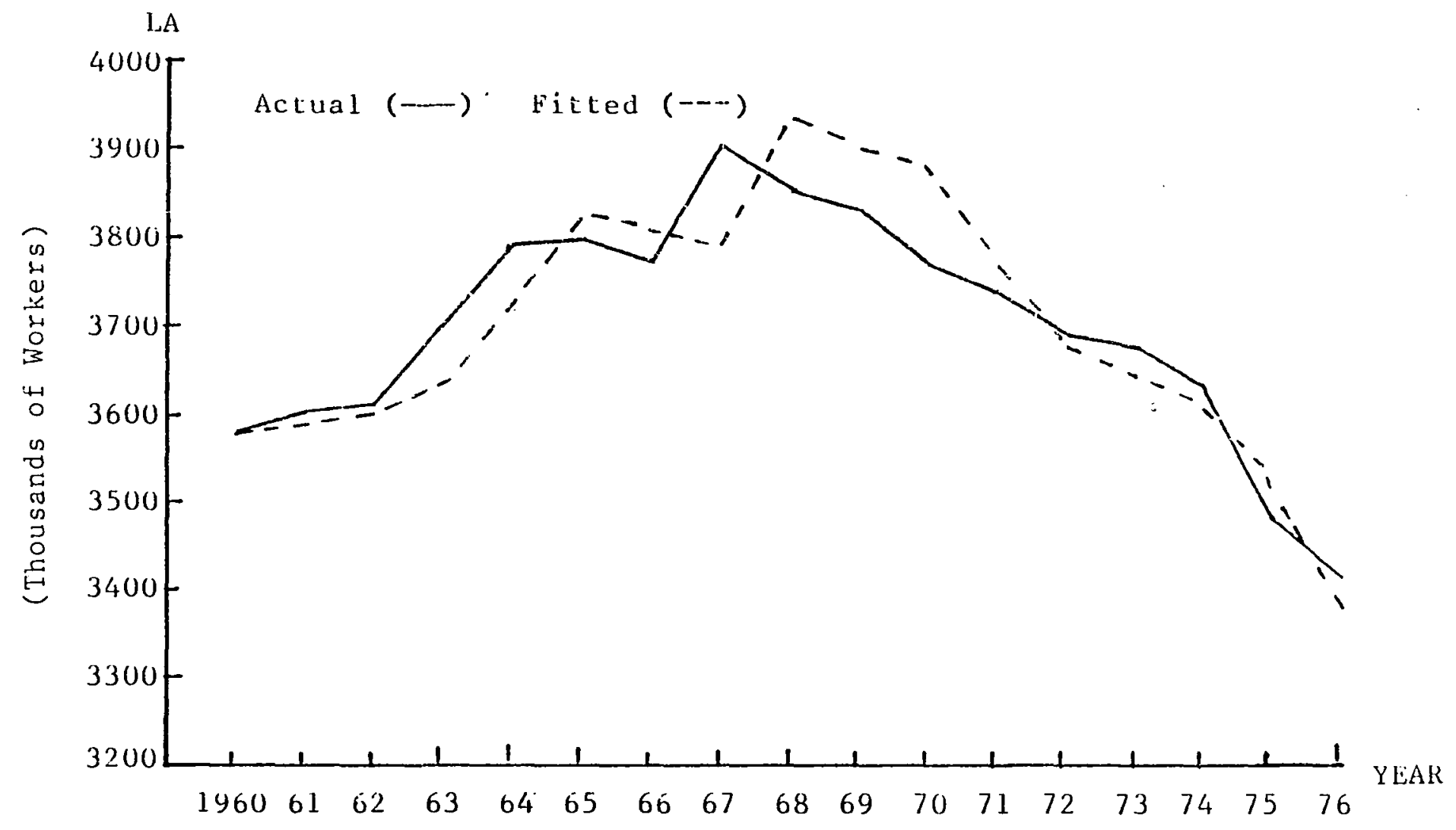

Figure 9. Historical Simulation of Labor Employed in Agriculture. 


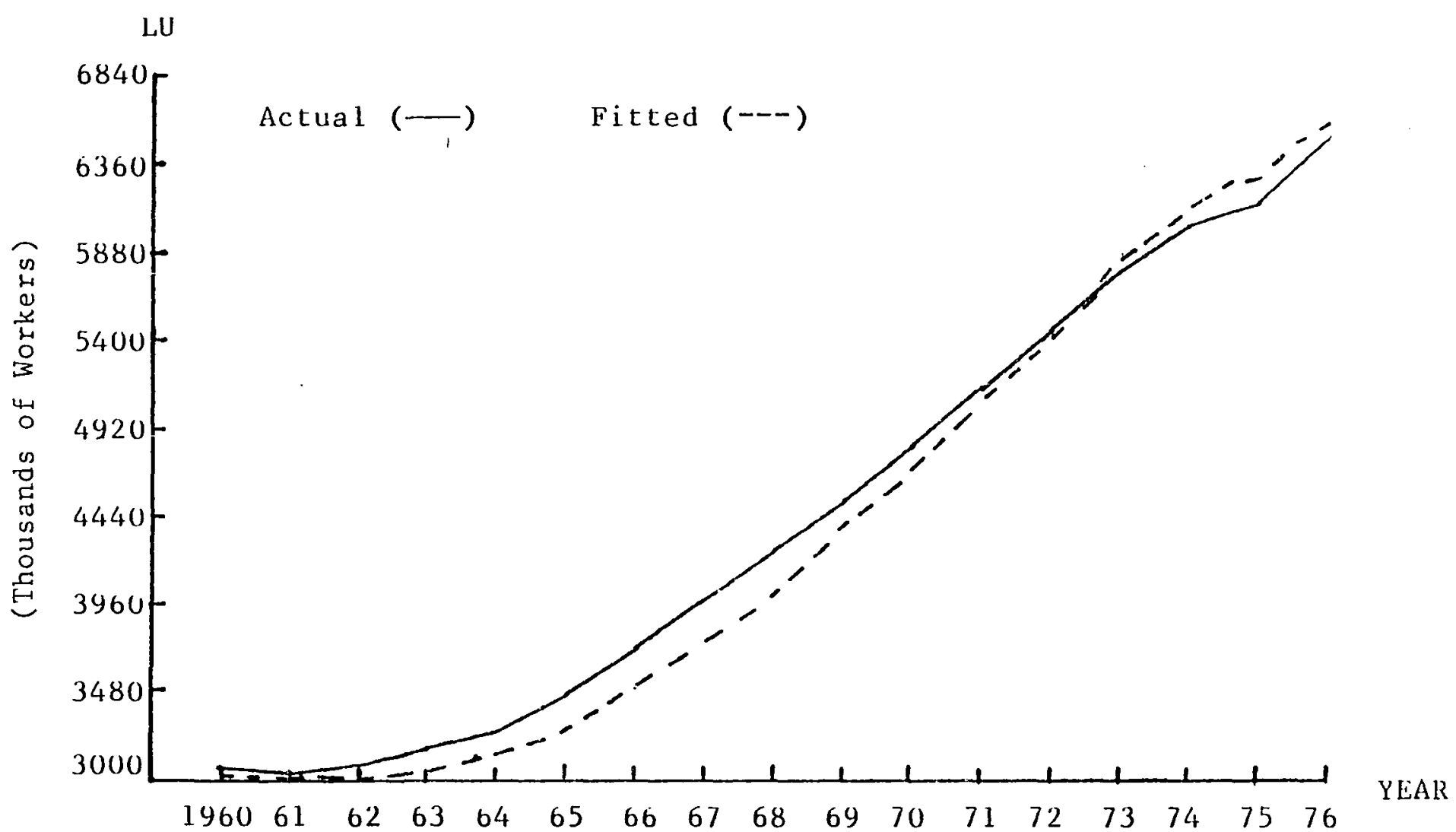

Figure 10. Historical Simulation of Labor Employed in Urban Sector. 


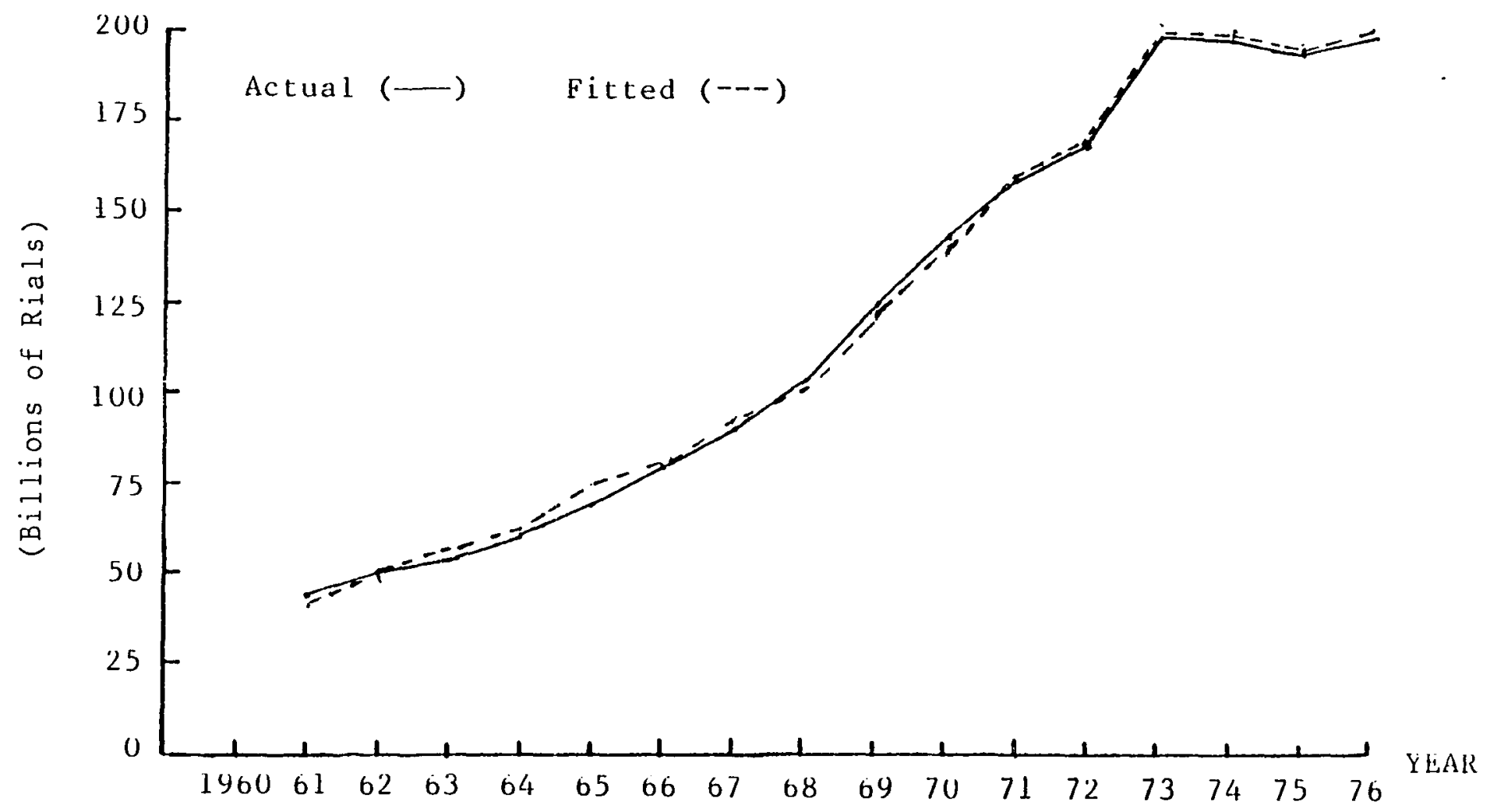

Figure 11. Historical simulation of Value-Added in 0il sector. 


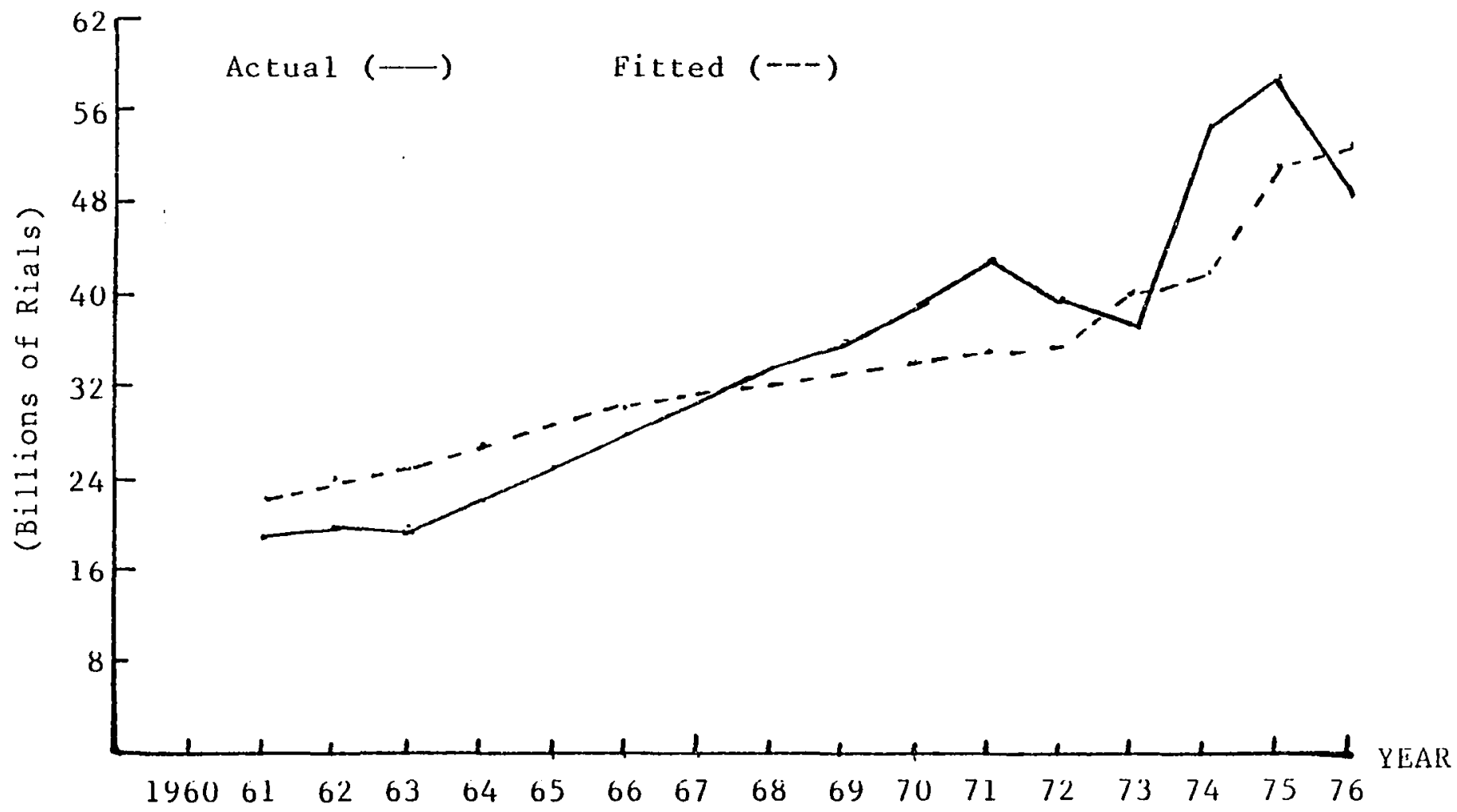

Figure 12. Historical Simulation of Net Indirect Taxes. 
The Reduced Form of the Model

Equations 1 to 12 listed in Table VI represent the structural form of the model. The structural equations may be regarded as a theoretical explanation or hypothesis about the structure of the economy. Structural equations are, however, the "implicit functions" where the current endogenous variables may appear on the right-hand side of the equation. To find the current endogenous variables solely as a function of predetermined variables, i.e., exogenos and lagged endogenous, the structural equations are transformed into the reduced form where each current endogenous variable is an "explicit function" of predetermined variables.

The equations represented in Table VII constitute the reduced form of the model. The coefficients of the reduced-form equations measure the impact in the current period on each endogenous variable of a unit change in any predetermined variable. Consider for example a unit increase in the level of INVU1. From equation (1) of the structural form there would be a simultaneous increase of .44 unit in value added in the urban sector. But from the employment function of the urban sector, i.e., equation (10), increases in INVU1 will induce increases in employment which in turn will induce further increases in VAU. The coefficients of reduced-form equations are called 
TABLE VII

REDUCED FORM EQUATIONS

(1) $\mathrm{VAU}=-1.1+\mathrm{VAU} 1+.46$ INVU1

(2) $\mathrm{VAA}=-9.2+\mathrm{VAAI}+.67 \mathrm{INVA}+.1 \mathrm{GLA}+.05$ GLAND

(3) $\mathrm{VAO}=-6.8+.99 \mathrm{EXO}$

(4) $\mathrm{CU}=-.32+.29$ VAU1 +.13 INVU1 $+.57 \mathrm{CU} 1+.002$ POPR

(5) $\mathrm{CR}=-3.6+.4 \mathrm{VAA}+.27$ INVA +.04 GLA + .02 GLAND $+.6 \mathrm{CR} 1+.001 \mathrm{POPR}$

(6) $\mathrm{CG}=7.22+.89 \mathrm{CGI}+.01 \mathrm{EXO}+.1 \mathrm{IMC} 1+.03 \mathrm{INVU}$ +.05 VAU1 + .004 INVU1 + .01 VAA +.005 INVA $+.001 \mathrm{GLA}+.001$ GLAND

(7) IMC $=-22.31+.06$ VAAI +.03 INVUI +.04 INVA $+.06 \mathrm{EXO}+.001 \mathrm{GLA}+.003 \mathrm{GLAND}+.73 \mathrm{IMC1}$

(8) IMK $=-37.4+.25$ INVU +.3 VAU1

(9) EXNO $=-24.92+.35$ VAAI +.23 INVA +.04 GLA +.02 GLAND

(10) $\mathrm{LU}=-160.1+\mathrm{LU} 1+.6$ INVU1

(11) $\mathrm{LA}=3945.7-.98$ INVU1 -5.55 INVA

(12) $\mathrm{NIT}=23.31+.02 \mathrm{VAU} 1+.003 \mathrm{VAA} 1+.002$ INVU1

+0.1 INVU +.002 INVA +.003 EXO +.04 IMC1 
"impact multipliers", because they show the effect in the current period of changes in predetermined variables. The impact effects in the current period are not the end of the story. A one-step change in an exogenous variable sets off a sequence of changes in the dependent variable because of the lags in the system. The estimated reduced form can be applied sequentially to trace out the dynamic effects of an assumed change in any exogenous variable. The changes in the dependent variable are called "dynamic multipliers" and the total long-run multiplier is just the sum of all dynamic multipliers over time. ${ }^{9}$ The effects over a five year period of a unit change in INVU1, INVA, VAU1, VAA1, EXO are given in tables VIII to XIV. In the case of $C U, C R, C G$ and IMC, dynamic multipliers vanish after a period of about five years. In the case of VAU, VAA, and LU they remain the same since the coefficients of VAU1, VAAl and LUI are equal to one. This may indicate that the value of these estimated coefficients are rather high. But even if we assume a much lower coefficient say for example.95, it still takes a long time for multipliers of VAU, VAA and LU to level off. Note that while the total effects of investment multiplier in the urban sector in the first five and ten years is quite large compared with the economically advanced industrial countries, the import multiplier is quite small. Impact multipliers of other policy variables except INVU1 for employment in urban 
TABLE VIII

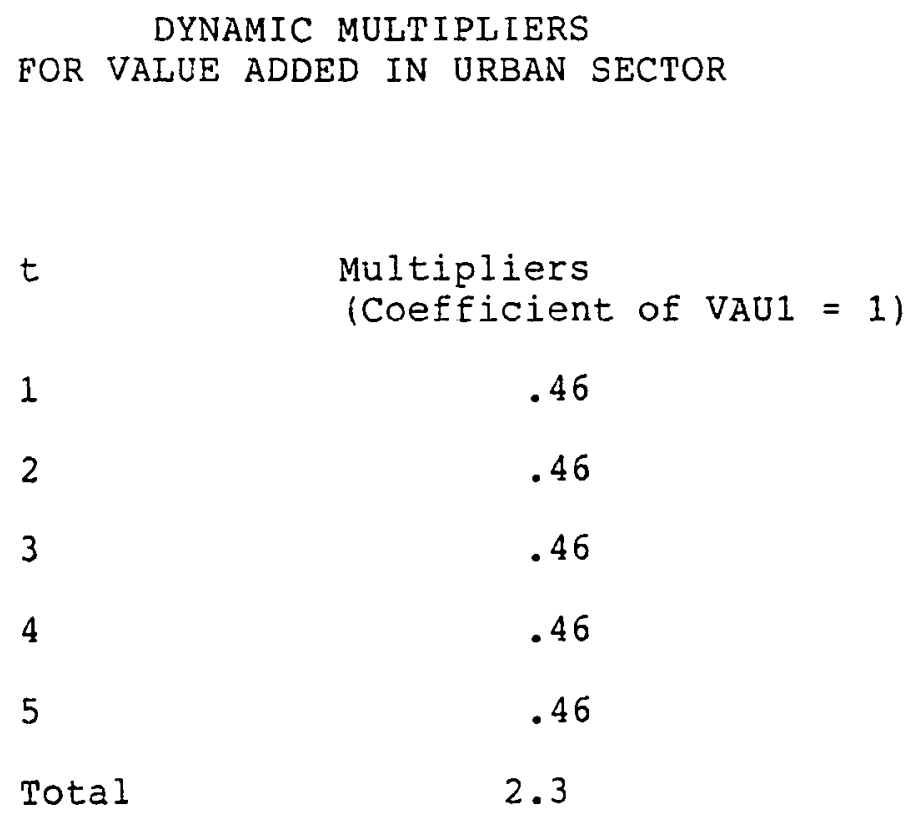

TABLE IX

DYNAMIC MULTIPLIERS

FOR VALUE ADDED IN RURAL SECTOR

$t$

Multipliers

(Coefficient of $\mathrm{VAA}=1$ )

$I$

.67

2.

.67

3

.67

4

.67

5

.67

Total

3.35 
TABLE $X$

DYNAMIC MULTIPLIERS

FOR URBAN CONSUMPTION

$t$

Multipliers

(Coefficient of $\mathrm{CU} 1=.57$ )

1

.29

2

.165

3

.094

4

.054

5

.031

Total

.634

TABLE XI

DYNAMIC MULTIPLIERS

FOR RURAL CONSUMPTION

t

Multipliers

(Coefficient of $\mathrm{CR} 1=.6$ )

1

.4

2

.24

3

.144

4

.0864

5

.0518

Total

.922 


\section{TABLE XII}

DYNAMIC MULTIPLIERS FOR

GOVERNMENT CONSUMPTION

\begin{tabular}{|c|c|}
\hline$t$ & $\begin{array}{l}\text { Multipliers } \\
\text { (Coefficient of CGI }=\end{array}$ \\
\hline 1 & .01 \\
\hline 2 & .009 \\
\hline 3 & .008 \\
\hline 4 & .007 \\
\hline 5 & .006 \\
\hline Total & .04 \\
\hline
\end{tabular}

TABIE XIII

DYNAMIC MULTIPLIERS FOR

IMC, POLICY VARIABLES

$\begin{array}{lc}t & \begin{array}{c}\text { Multipliers } \\ \text { (Coefficient of IMC1 }=.73) \\ 1 \\ 2 \\ 3\end{array} \quad .03 \\ 4 & .02 \\ 5 & .016 \\ \text { Total } & .012 \\ & .009 \\ & .087\end{array}$


TABLE XIV

DYNAMIC MULTIPLIERS FOR

LU. POLICY VARIABLE; INVU1

$t$

Multipliers

(Coefficient of LU1 = 1)

1

.6

2

.6

3

.6

4

.6

5

.6

Total

3 
sector are also very low, compared to the commonly proposed multiplier of 2 to 2.5 for industrialized countries. 
NOTES

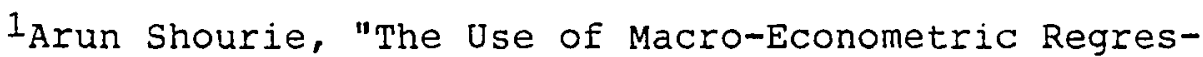
sion Models of Developing Countries for Forecasts and Policy Prescription: Some Reflections on Current Practice" in Oxford Economic Papers, March, 1972, pp. 1-35.

${ }^{2}$ Plan and Budget Organization, Economic Trends of Iran, (Tehran: Operations Research Bureau, 1978).

${ }^{3}$ B. H. Hall and R. E. Hall. Time Series ProcessorUser's Manual, (London, Ontario: The University of Western Ontario, 1980), pp. 20-25.

${ }^{4}$ A. Kautsoyiannis, Theory of Econometrics, second Edition, New York: Barnes \& Noble Books, 1978, p. 475.

5L. R. Klein, "The Treatment of Underutilized Samples in Econometrics", In Econometric Studies of Macro and Monetary Relations, Edited by Alan A. Powell and Ross, A. Williams, New York: North-Holland Publishing Company, 1973, pp. 6-11.

$6 \mathrm{~J}$. Johnston, Econometrics Methods, p. 485; A. Kennedy, A Guide to Econometrics, pp. 134-140; R. S. Pindyck, Econometric Models and Economic Forecasts, pp. 286 ; and P. Wannacot, Econometrics, pp. 295.

${ }^{7}$ Capital-output ratios for $1959-1967$ are calculated by the Central Bank of Iran ard are published in Bank Markazi Iran, National Income of Iran 1962-67. (Tehran: Bank Melli Iran Press, 1969), Pp. 129-135.

${ }^{8}$ The Central Bank of Iran recommended the use of a 78 annual depreciation rate of the capital stock.

${ }^{9}$ Homa Katouzian. The Political Economy of Modern Iran, (New York: New York University Press, 1981), pp. 304-307.

${ }^{10}$ R. S. Pindyck and D. L. Rubinfeld. Econometric Models and Economic Forecasts, (New York: McGraw-Hill Book Company, 1976), pp. 308-320.

11 Pindyck and Rubinfeld, pp. 346-349. 
Our purpose in this study has been to increase our knowledge of the structure and behavior of an oil-based developing economy.

The economic licerature attests to the fact that an increasing number of eccnomists are questioning the realism as well as relevance of conventional economic theories to the developing countries. As H. Myint has pointed out there can be no serious quarrel with those critics who stress the need to increase the realism of economic theory by taking into account historical and institutional characteristics of developing countries. However, the argument of those economists who question the relevance of economic theories is more debatable. In our view the acceptance or rejection of the relevance of conventional economic theories to the developing economies should be based on the results of the empirical investigations rather than conjecture. In fact, the result of this study is a case in point. Our research demonstrates that the proposed econometric model satisfactorily explains the behavior of Iran's macroeconomic variables. Furthermore, it is found that the application of Friedman's Permanent Income Hypothesis to 
the Iranian aggregate consumption data yields plausible results.

Summary

Clearly, the developing economies might draw on some of the conventional economic theories for constructing econometric models. But, models built for the developing economies should reflect local instizutions and behavioral characteristics.

Econometric models built for oil-exporting developing countries should reflect the two basic dualities, namely, the traditional duality of the agriculture and industrial modern sector anc the oil duality characterized by an enclave modern oil sector with little direct link to the rest of the economy. The linkages between the oil sector and the rest of the economy are established through state investment anc consumption expenditures. The mode: also should be disaggregated so that growth of agriculture and modern urban sector as well as consumption expenditures in these sectors can be studied. Furthermore, the dominance of foreign trade should be taken into account with emphasis on consumer goods, capital and intermediate imports.

our model includes private consumption expenditures in Iural and urban sectors, state consumption expenditures, import of consumer goods, imports of capital and intermediate goods and non-oil exports. The supply functions include 
value added equations for agriculture as well as modern urban and oil sectors. Investments made in agriculture and urban sector are assumed to be exogennus variables. There are two basic reasons for making this assumption. First, the model is only concerned with the real aspect of the Iranian economy and monetary factors such as interest rate, supply of money, and credits are excluded from the model. Second, in contrast to the classical case, in an oil-based economy, investments largely depend on the oil revenue and government expenditures and hence to a large extent is independent from output and production capacity. Considerable compromises, however, have been made between constructing an ideal model of an oi.l-exporting dualistic economy such as Iran and the available data. These compromises have been most significant with respect to demographic and institutional factors, infrastructure, capital and capacity restraints in production process, rural-urban migration and direct treatment of: ircone distribution.

The estimation of the coefficients of the independent variables are estimated by ordinary least squares and twostage least squares. Furthermore, historical simulation is performed to test the validjty of the model. In general the results of simulation are quite satisfactory and indicate an overall fit of the estimated model. 


\section{Conclusions}

Three different formulations explaining the private consumption functions in rural and urban sectors are estimated. The results seem to indicate that Iranian consumption behavior can best be explained by ariedman's permanent Income Hyoothesis. The results from 3rown's and keynesian formulations are unsatisfactory. Iranian data seem, however, to fit Brown's formulation better than Keynesian hypothesis. Jong-run narginal propensities to consume are calculated for urban and rural areas. The marginal propensity to consume, in rural sector, as me expected is very bigh (.97). Our estimate shows that the numerical value of the long run marginal propensity to consume in urban sector is about (.5) which indicates a substantial amount of savings in the urban sector compared to almost zero savings in the rural areas.

An attempt has been made to estimate the urban's sector aggregate production function according to various Cobb-Douglas production functions and linear production function with constant returns to scale. All of these specifications give implausible results, such as negative labor share, insignificant efficiency parameter. But the results obtained from the suggested supply functions are relatively good and indicate what the marginal productivity of labor in agriculture Eector is far from zero in contrast to the assumption made by traditional dualistic models. 
As for the effects of investment expenditures on the level of employment in agriculture and urbar sector, the results obtained attest to the fact that development policies of the Iranian government over the estimation period were inappropriate due to their capital intensive and modernist character. Clearly, investment projects which carried out in the rural and in the urban sectors failed to address the problem of unemployment. In agriculture sector such investments led to poverty and unemployment among peasantry and high rate of migration to urban areas. In urban sector industrialization strategy of the government emphasized the expansion of modern capital-intensive manufacturing industry as well as construction, both from the demand and from the supply side of the market. The labor-absorptive capacity of the new industries was extremely low and the share of their workforce was also low. The state also encouraged the use and provision of different kinds of modern services which are highly capital intensive with a low labor-absorption capacity.

The reduced form of the model demonstrates that the links between the different sectors of the economy are very weak. The economy as a whole, and particularly the urban sector is found to exhibit a high reliance on imports from abroad for capital as well as consumer goods. The import equation for capital goods shows the existence of a positive, instead of a negative, relationship between the 
investments made in the urban sector and the import of capital and intermediate goods.

Furthermore, it indicates a strong positive correlation with the value added of the urban sector. These results imply that the industrial policy of the state did not succeed to increase sjgnificantly the domestic production of goods and services. In other words government import substitution strategy totally failed to reduce the Iranian economy's dependerce on foreign resources over the period under consideration.

Non-oil exports consists of the agricultural and new industrial goods. Nevertheless only value added in agriculture has been found to be statistically significant in explaining the non-oil exports and for good reasons. The share of agricultural products amounted to more than eighty percent of the total non-oil exports, even in the second half of 1970 s.

All of the exogenous variables are found to have an impact effect on value added in urban and rural sectors well below the commonly proposed multiplier of 2 to 2.5 , for industrialized countries. Investments made in urban and rural sectors have the highest impact effect upon corresponding value added. In contrast labor has a small impact. Dynamic multipliers of investment for value added in urban and rural sector, however, take a long time to level off and their magnitudes are relatively large 
compared with developed countries. It could be deduced that the time period required for multipliers to level of depends on the structure of an economy: especially its lag structure and the efficiency of its stabilizers. To the extent that less developed economies tend to have a more simplified stabilizing system than developed economies, an indirect link could be established between development and time needed for the multipliers to level off. Furthermore it is found that the impact multipliers of other policy variables except investment variable in the employment equation are very low and dynamic multipliers for consumption and imports of consumer goods vanish after a short period of time.

\section{Recommendations}

The preceding discussion suggests that a basic reorientation of old economic policies and practices is necessary. The failure of Iran's pattern of development clearly demonstrates that a genuine development can not be achieved through the importation of machinery and foreign expertise in a disorganized manner and in isolation from the domestic production structure. Besides this kind of artificial and hollow development leads to an extremely uneven distribution of financial resources and income in the economy as a whole and between urban and rural sectors in particular. In general, there is a need for a strategy of development 
as self-reliant as possible, based on a proper balance between agriculture, heavy industries and light consumer industries, reducing dependency on advanced industrialized countries.

In the light of foregoing analysis, and also the results obtained from this study, an attempt has been made to illustrate a consjstent set of policies which may be considered in design and implementation of development policies in the future. It should be noted that the following suggestions are neither complete, nor carefully integrated nor particularly original. They are only presented as an invitation to further thinking and action.

(a) The redistribution of land through a comprehensive land reform and rural development plans. This must include extensive nation wide activities in helping the peasants in the field of irrigation, supply of electricity, housing, supply of fuels, pesticides and fertilizers, building of roads, provision of sanitary and therapeutic services, and provision of educational and medical services. (b) Creation of a capital goods sector and paying special attention to home-mgrown industry. In both areas, the objective is to move in the direction of self-sufficiency, promotion of appropriate technology and output mix. Industry should produce basic consumer and producer goods required by people such as processed food, clothing, household goods, buses, various tools and instruments as 
well as the basic inputs to agriculture and manufacturing. Both in industry and agriculture whenever possible an allaround employment and a more egalitarian distribution of income should be promoted by adoption of labor-intensive techniques.

(c) Mobilization of idle labor and creation of infrastructure especially in rucal areas. Besides being employment-creating, such activities can contribute towards the acceleration of investment through the direct application of labor. Capital stock is also often under-utilized. In this regard special emphasis should be placed on provision of technical and managerial training and educhtion.

(d) Selective import substitution policies should be pursued in the area of international trade. While machinery and some raw materials would continue to be imported to the extent necessary, imports of unnecessary consumers goods should be eliminated.

As the text makes it abundantly clear the model that has been put forward in this study is a simple model and there is definitely room for substantial improvements. It is hoped, however, that the present model will be of some help to future formulations. If data became available the model itself could be enlarged to include production functions in manufacturing, services, construction and water and power. Consumption functions may be disaggregated to 
represent food as well as non-food consumption equations. It could be of some interest to include and specify the investment functions for each sector. It could be also possible to introduce a demographic submodel with special attention to rural urban migration. Improved statistics would also lead to improved employment functions, and the model could be enlarged even further to treat direct taxation, prices and monetary sector. 


\section{BIBLIOGRAPHY}

Adelman, I. and E. Thordecke, The Theory and Design of Economic Development, Baltimore: Johns Hopkins Press, 1966 .

Adelman, Irma, and Holiss B. Chenery, "Foreign Aid and Economic Development". The Review of Economics and Statistics, Vol. XLIII, No. 1 (Feb. 1966).

Alnasrawi, Abbas, Einanging Economic Development in Iran: The role of oij. in a Middle Eastern Economy, New York: Praeger, 1967 .

Amin, Samir, Imperialism and Unequal Development, New York: Monthly Review, 1977.

Amuzegar, J. and M. A. Fekrat, Economic Development Under Dualistic Conditions, Chicago: University of Chicago Press, 1971.

Amuzegar, J., Iran, An Economic Profile, Washington, D.C.: Middle East Institute, 1977a.

- Iran, An American Profile, Washington, D.C.: Middle East Institute, 19775 .

Baumol, W. J., Economic Dynamics, New York: The Macmillan Company, 1951 .

Banani, Amin, The Modernization of Iran, 1921-1941, Stanford: Stanford University Pross, 1961.

Barisch, william, "The Industrial Labor Force of Iran: Problems of Recruitment, Training and Productivity", The Population of Iran: A Selection of Readings, edited by Jamshid Momeni, Honolulu, East-West Center, 1977.

Bharier, Julian, Economic Development in Iran: 1900-1972, New York: Oxford University Press, 1971.

Binder, Leonard, Iran: Political Development in a Changing Society, Berkeley: University of California Press, 1962 .

Bos, Henk C., "Some Simple Thoughts on Model Building for Developing Countries", The Pakistan Development Review, 22, 1983, pp. 63-71. 
Campagna, Anthony S., Macroeconomics Theory and Poilcy, Boston: Houghton Mifflin, 1974 .

Brun, Thierry, and Dumont, Rene, Iran: Imperial Pretensions and Agricultural Dependence.

Burmeister, E. and A. R. Dobell, Mathematical Theories of Economic Growth, London, 1970 .

Carey, Jane and Carey, Andrew, "Iranian Agriculture and its Development: 1952-1973", International Journal of Middle East Studies, July, 1976.

Chenery, H. B. , Studies in Development Planning, Cambridge, Mass.: Harvard University Press, 1971.

Chenery, H. B., and Macewan, "Optimal Patterns of Growth and Aid: The Case of Pakistan", Pakistian Development News, Summer 1960.

Compagna, A. S., Macroeconomics Theory and Policy, Boston: Houghton Miffin, 1974.

Daftary, Farhad, "Development Planning in Iran: A Historical Survey", Iranian Studies, 6, Autumn, 1973.

Dixit, A. K., "Optimal Development in the Labor Surplus Economy", Review of Economic Studies, January 1968.

Doroudian, Reza, "Modernization of Rural Economy in Iran", Iran: Past, Present, and Future, edited by Jane Jacgz, New York: Aspen Institute for Humanistic Studies, 1976.

Eckaus, R. S., "The Factor Proportions Problem in Underdeveloped Areas", American Economic Review, September, 1955 .

Evans, M. K., Macroeconomic Activity, Theory, Forecasting and Control, New York: Harper and Row, 1969.

Fei, J. C. H., and G. Ranis, "A Theory of Economic Development", American Economic Review, September 1961. - Development of the Labor Surplus Economy, Homewood: Richard D. Irwin, 1964.

Fekrat, A. M., "Growth of OPEC-Type Economies: A Preliminary Theoretical Inquiry". Economica Internationale, February 1979. 
Eox, K. A., J. K. Sengupta, and E. Thorbecke, The Theory of Quantitative Economic Policy, Chicago: Richard McNallgh Company, 1960.

Furtado, C., Development and Underdevelopment, Berkeley: University of California Press, 1963 .

Graham, Robert, Iran: The Illusion of Power, New York: st. Martins Press, 1979 .

Holliday, Ered, Iran: Dictatorship and Development, New York: Penguin; 1979 .

Hagen, E. E., Planning Economic Development, Hornewood: Richard D. Irwin, 1968.

Hal1, Brownyn H. and Robert E. Hall, Time Series ProcessorUser's Manual, London, Ontario, The University of Western ontario, 1930.

Hemmasi, Mohmmad, Migration in Iran: A Quantitative Approach, Siniraz: Panlavi University, 1974.

Hirsch, Etlenne, Employment and Income Policies for Iran, Lausanne: presses Centrales, 1973.

Hirschman, A. O., "Economic Policy in Underdeveloped Countries", in B. Okvn and R. N. Richardson (eds.), Studies in Economic Development, New York: Holt, Rinehart and Ninston, 1971.

- "The Political Economy of Import-Substitution Industrialization in Iatin America", The Quarterly Journal of Economics, February 1963.

- The Strategy OE Economic Development, New Haven: Yale University press, 1971 .

Hobbs, John, "Land Reform in Iran: A Revolution from Above" ORBIS, 7 (FaIl, 1963).

Iran, Bank Markazi, Annual Report and Balance Sheet, Tehran, BMI, 1968-1976.

Iran, Bank Markazi, National Income of Iran 1962-67, Tehran, Iran, Bank Melii Iran Press, 1969.

Iran, Plan Organization, Fourth National Development Plan: 1968-1972.

Iran, Plan and Budget Organization, Iranian Statistical Center Publications, 1973-78. 
Iran, Plan and Budget Organization, Economic Trends of Iran, Tenran, Iran, Operations Research Bureau, 1978.

Issawi, Cnarles, "The Iranian Economy 1925-1975: Fifty Years of Economic Development", Iran Under the Pahlavis, Edited by George Lenczowski, Stanford, California: Hoover Institution Press, 1978.

Jacqz, Jan, ed. Iran: Past, Present and Future, New York: Aspen Institute Eor Humanistic Studies, 1976.

Joinston, J., Econometric Methods, New York: McGraw-Hill Boo's Company, 1984 .

Jorgenson, D. W., "Surplus Agriculture Labor and Development of a Dual Economy", Oxford Economic Papers, November 1967.

- "The Development of a Dual Economy", Economic Journal, June 1961.

Jones, H. G., An Introduction to Modern Theories of Economic Growth, New York: McGraw-Hill Book Company, 1975 .

Katouzian, Homa, The Political Economy of Modern Iran, New York: New York University Press, 1981.

Katozian, M. A., "Oil Versus Agriculture: A Case of Dual Resource Depletion in Iran". Journal of Peasant Studies, 5, (August 1978), 34 7-69.

Kautsoyiannis, A., Theory of Econometrics, Second Edition, New York: Barnes \& Nobel, 1978 .

Kazeni, Farhud, Poverty and Revolution in Iran, New York: New York University Press, 1980.

Kelly, A. C. and J. G. Williamson, and Cheethan, Dualistic Economic Development, Chicago: University of Chicago Press, 1972 .

Kennedy, Peter, A Guide to Econometrics, Cambridge: The MIT Press, 1979 .

Keynes, Join M., The General Theory of Employment, Interest and Money, London: Macmillan, 1963.

Keynes, John M., The General Theory of Employment, Interest and Money, London: Macmillan, 1963. 
Kindleberger, Charles C., Economic Development, Second Edition, New York: McGraw-Hill Book Company; 1965.

Klein, L. R., "What Kind of Macroeconometric Model for Developing Economies?", Readings in Economic Statistics and Econometrics, edited by Arnold zellner, Boston: Little, Brown and Company, 1968.

Klein, L. R., and R. M. Young, An Introduction to Econometric Forecasting and Forecasting Models, Lexington: Lexington Books, 1980 .

Kuznets, S., Toward a Theory of Economic Growth, New York: W. W. Norton and Company, 1968.

Lewis, W. A., "Economic Development with Unlimited Supplies of Labour", Manchester School, May 1954, pp. 139-91.

Livingstone, I., Edited, Economic Policy for Development, Middlesex, England: Penguín Books, Ltd., 1971.

Looney, Robert, A Developmental Strategy for Iran Through the 1980's, New York: Praeger Publishers, 1977.

- The Economic Development of Iran: A Recent Survey with Projections to 1981, New York: Praeger Publishers, 1973.

Mayes, David G., Applications of Econometrics, Englewood Cliffs, New Jersey: Prentice Hall International, 1981 .

Maddala, G. S., Econometrj.cs, New York: McGraw-Hill Book Company, $19 \overline{77 .}$

Mahalanobis, P. D., "The Approach of Operational Research to Planning in Indian", Sankhya, December 1955, pp. 3-130.

Morton, P., "Surplus Agricultural Labor and Development: Facts and Theories", American Economic Review,

september 1965, pp. $815 \cdots 834$.

Myint, Hla, "The Classical Theory of International Trade and Underdeveloped Countries", Economic Theory and the Underdeveloped Countries, edited by Hla Myint, New York: Oxford University press, 1971.

Myrdal, G., An Approach to the Asian Drama, New York: Vintage Books, 1970 . 
Nurkse, R., Problems of Capital Formations in Underdeveloped Countries, New York: University Press, 1953 .

Pindyck, R. S., Optimal Planning for Economic Stabilization, Amsterdam: North-Holland Publishing Company, 1973.

Pindyck, R. S. and D. L. Rubinfeld. Econometric Models and Economic Forecasts, New York: MCGraw-Hill Book Company, 1976.

Plan and Budget Organization, Economic Trends of Iran, Tehran: Operations Research Bureau, 1978.

Qayum, Abdul, Techniques of National Economic Planning, Bloomington: Indiana University Press, 1975.

Rosenstein-Rodan, P. N., "Notes on the Theory of the Big Push", Economic Development for Latin America, New York: St. Martins Press, 1961.

Rostow, W. W., The Stages of Economic Growth, New York: Cambridge University Press, 1960.

Schumpeter, J. A., The Theory of Economic Development, Cambridge: Ilarvard University Press, 1934.

Scitovsky, T., "Two Concepts of External Economies", The Economics of Underdevelopment, edited by $A . N$. Agarwala and S. P. Singh, New York, 1963.

Shahshahani, Ahmad and J. Malcolm Dowling, "An Econometric Model Forecast of Iran, 1975-1985", The Journal of Energy and Development, Autumn, 1976.

Shourie, Arun, "The Use of Macro-Econometric Regression Models of Developing Countries for Forecasts and Policy Prescription: Some Reflections on Current Practice", Oxford Economic Papers, March 1972, pp. $1-35$.

Singh, K. S., Development Economics, Lexington: Lexington Books, 1975 .

Todaro, M. P., Economic Development in the Third World, London: Longman, 1977.

United Nations, Trade Prospects and Capital Needs of Developing Countries, New York: UNCTAD, 1968.

United Nations, Feasible Growth and Trade Gap Projections in the ECAFE Region, Bankog: ECAFE, 1968 . 
Vakil, Firouz, "An Econometric Model for Iran", Bank Marzi Iran Bulletin, Vol. 11, (vuly-August, 1972).

- "An Econometric Model for Iran: Estimated structured Equations", Bank Markazi Iran Bulletin, Vol. 11, (September-November, 1972).

- "An Econometric Model for Iran: Estimated structured Equations", Bank Markazi Iran Bulletin, Vol. 11, 1973.

- "Iran's Basic Macroeconomic Problems: A TwentyYear Horizon", Economic Development and Cultural Change, July 1977, po. 713-727.

Wallich, H. C., "A Theory of Derived Derelopment", The Economics of Underdevelopment, edited by $A$. N. Agruwala and S. P. Singh, New York: Oxford University Press, 1963.

Wonnacott, Paul, Macroeconomics, Homewood, Illinois: Richard D. Irwin, Inc., 1984.

Zarembka, Paul, "Marketable surplus and Growth in the Dual Economy", Journal of Economic Theory, 2, 1970, pp. 107-121. 
APPENDIX A

A SUMMARY OF QUANTITATIVE CHANGES AND STRUCTURAL SHIFTS IN THE IRANIAN ECONOMY OVER

1959-76 PERIOD

\begin{abstract}
All variables are for annual time periods and in billion of rials and thousand of persons. All variables are in terms of constant 1959 prices.
\end{abstract}


SECTORAL PATTERNS OF GROWTH

(Percentages)

\begin{tabular}{|c|c|c|c|c|}
\hline & \multicolumn{4}{|c|}{ AVERAGE ANNUAL GROWTH } \\
\hline & $1960-62$ & $1963-67$ & $1968-72$ & $1973-76$ \\
\hline Agriculture & 1.28 & 4.62 & 3.52 & 6.1 \\
\hline Industry & 8.41. & 13.05 & 12.7 & 17.78 \\
\hline Services & 3.62 & 9.58 & 13.7 & 16.7 \\
\hline Oil & 15 & 12.56 & 15.19 & 2.3 \\
\hline Urban Sector & 5.1 & 10.76 & 13.37 & 17.06 \\
\hline G.N.P. & 4.53 & 9.36 & 11.86 & 13.23 \\
\hline Non-Oil G.N.P. & 3 & 8.74 & 11.11 & 15.67 \\
\hline
\end{tabular}

SOURCE: Plan and Budget Organization, Economic Trends of Iran, 5th Edition, March 1978. 
SEC'IORAL DIS'TRIBU'IION OF GROSS NA'IIONAL, PRODUC'I 1959-76, SELECIEL YEARS (Billion Rials, 1959 Constant Prices)

\begin{tabular}{|c|c|c|c|}
\hline $\begin{array}{c}1962 \\
\text { Anount }\end{array}$ & 1967 & 1972 & $\begin{array}{c}1976 \\
\text { Allount }\end{array}$ \\
\hline OE G.N.D.l & (z of G.N.P. & ( of G.N.P.) & 18 of G.N.P \\
\hline
\end{tabular}

1. Agriculture

$\begin{array}{llllllll}88.73 & (27.35) & 111 & (21.9) & 131.5 & (14.83) & 166.87 & (11.45) \\ 57.71 & (17.79) & 106.2 & (20.95) & 192.84 & (21.75) & 370.89 & (24.46)\end{array}$

2. Industry

$57.71(17.79) \quad 106.2 \quad(20.95) \quad 192.84(21.75) \quad 370.89 \quad(24.46)$

Manufacturing and Mining

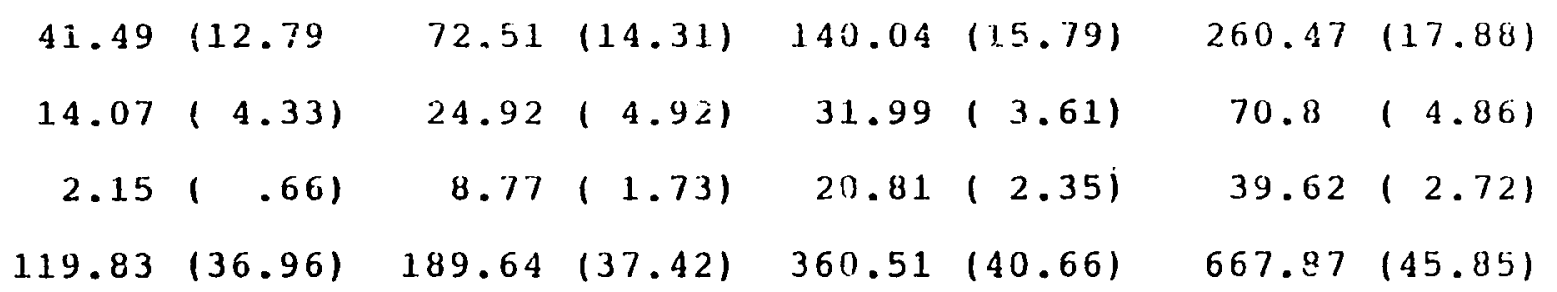

3. Services

\section{Public}

4. Oil

Services

\begin{tabular}{rrrrrrrr}
24.65 & $(7.6)$ & 48.66 & $(9.6)$ & 104.4 & $(11.74)$ & 171.73 & $(11.79)$ \\
50.12 & $(15.45)$ & 90.25 & $(17.81)$ & 182.65 & $(20.6)$ & 197.33 & $(13.55)$ \\
324.35 & & 506.8 & & 886.63 & & 1456.640 \\
\hline
\end{tabular}

5. G.N.P.a

a Includes indirect taxes and non-oil net factor income from abroad.

SOURCE: Plan and Budget organization, Economic Irends of Iran, 5th Edition, March 1978. 
PATTERN OF CONSUMPTION AND SAVING 1962-76

(Billions of Rials, 1959 Constant Prices)

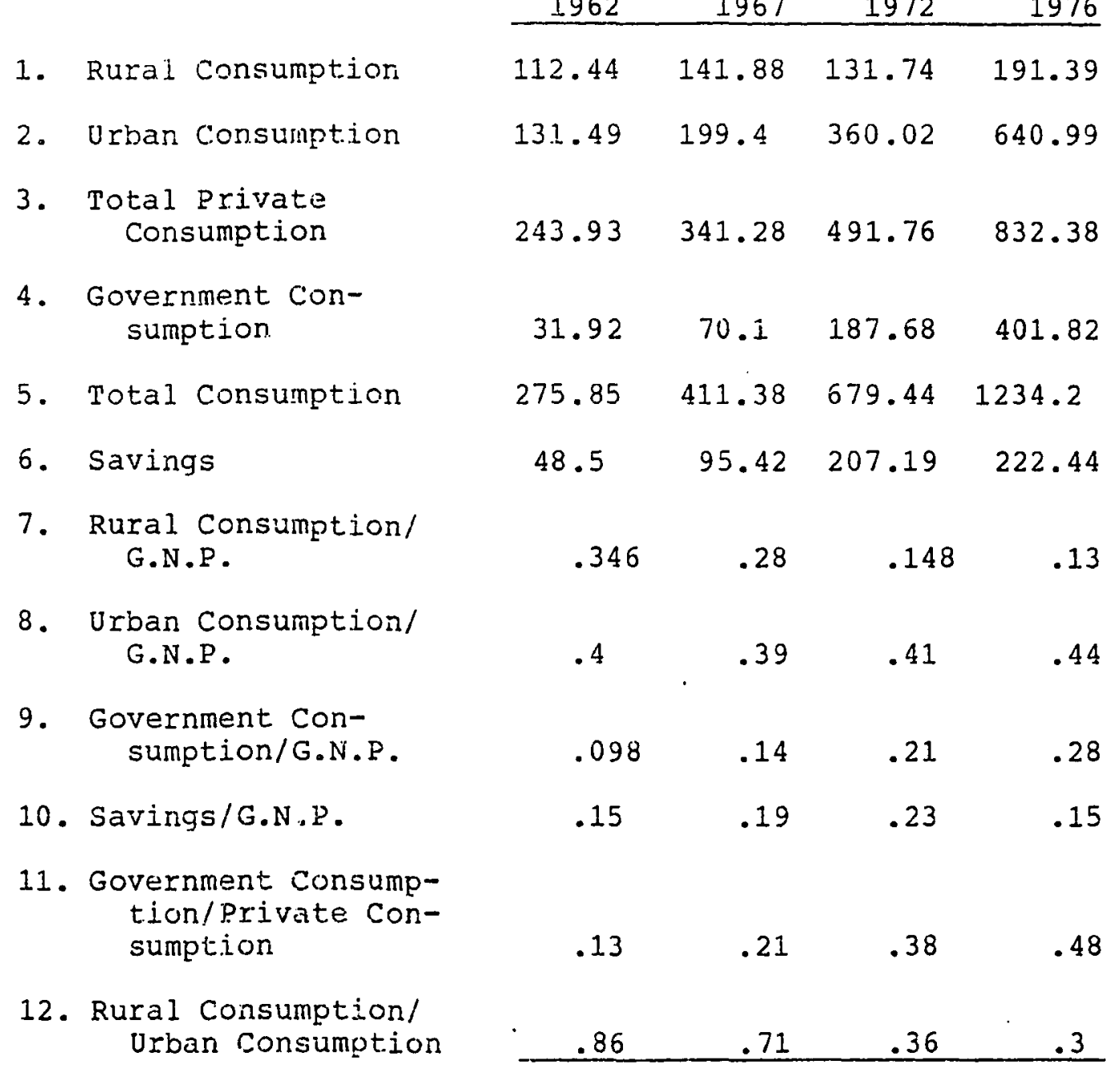

SOURCE: Plan and Budget Organization, Economic Trends of Iran, 5th Edition, March 1978. 
PER CAPI'IA CONSUMP'IION 1962-75

(qhousands Rials 1959 Constant Prices)

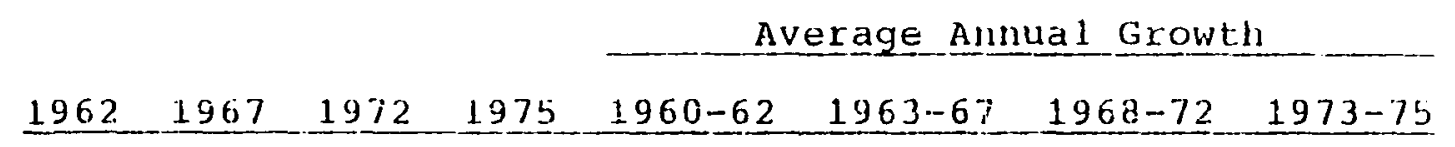

1. Rural Consumption

7.5

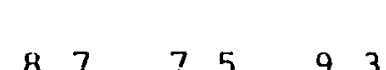

$1960-62$

$1963-67$

$196 a-72$

$1973-75$

2. Urban Food Consumption

8.

$8.9 \quad 11.6 \quad 15$.

.79

3.1

.2 .86

7.6

3. Urban Non-Pood Consumption
$8.2 \quad 10.4 \quad 16.2 \quad 23.3$
2.88
5.23
9.43
13.0

2.13

5.75

10.13

4. Urban Consumption

$\begin{array}{llllll}16.3 & 19.3 & 27.8 & 38.7 & 1.33\end{array}$

3.7

7.66

11.78

5. Urban Consumption/Rural Consumption

$\begin{array}{lllll}8.8 & 10.6 & 20.3 & 29.4\end{array}$

SOURCE: Plan and Budget Organization, Economic 'l'rends of Iran, 5 th Edition, March 1978. 
FOOD AND NON-FOOD CONSUMPTION IN URBAN AREAS

(Billions of Rials, 1959 Constant Prices)

\begin{tabular}{lcccc}
\hline & 1962 & 1967 & 1972 & 1975 \\
$\begin{array}{c}\text { Urban Food Cor- } \\
\text { sumption }\end{array}$ & 65.41 & 92.1 & 150.45 & 228.72 \\
$\begin{array}{c}\text { Urban Non-Food } \\
\text { Consumption }\end{array}$ & 66.08 & 107.3 & 209.57 & 345.81 \\
\hline & $1960-62$ & $1963-67$ & $1968-72$ & $1973-75$ \\
$\begin{array}{c}\text { Pattern of Growth } \\
\text { of Urban Food } \\
\begin{array}{c}\text { Consumption } \\
\text { (Percentages) }\end{array}\end{array}$ & 4.9 & & & 10.76 \\
\hline
\end{tabular}

SOURCE: Plan and Budget Organization, Economic Trends of Iran, 5th Edition, March 1978. 


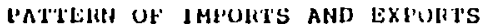

(billions of Rlals, 1959 Constant Frfcest

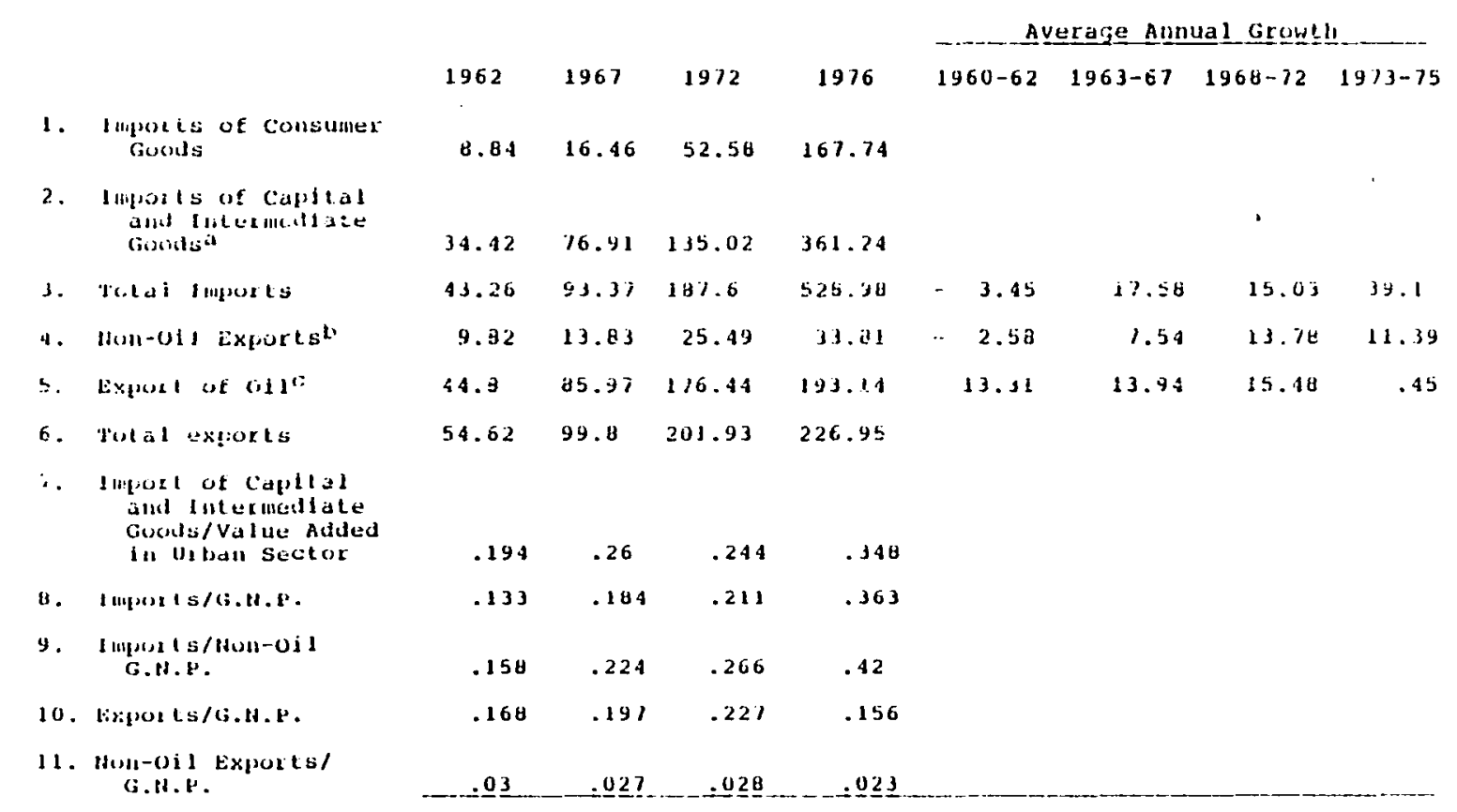

a Includes inports of services.

b Includes exports of services

c Includes exports of gas.

Sounck: Plan and Budget Organizatlon, Economic Iremls of Irall, Sth Edition, March 1978. 
PATTERNS OF INVESTMENT

(Billions of Rials, 1959 Constant Prices)

\begin{tabular}{l}
$1962 \quad 1967 \quad 1973 \quad 1976$ \\
\hline
\end{tabular}

1. Investment in Agriculture

$\begin{array}{llll}2.42 & 7.83 & 18.62 & 26.1\end{array}$

2. Investment in Urban Sector

$\begin{array}{llll}46.11 & 91.51 & 173.26 & 429\end{array}$

3. Private Investment $\begin{array}{llll}30.37 & 55.84 & 107.45 & 240.93\end{array}$

4. Government Investment

$18.16 \quad 54$

$105.87 \quad 278$

5. Total Investment $\begin{array}{llll}48.53 \quad 109.84 & 213.32 \quad 518.94\end{array}$

6. INVA/G.N.P. $\begin{array}{llll}.0075 & .015 & .021 & .018\end{array}$

7. INVU/G.N.P. $\begin{array}{llll}.142 & .18 \quad .195 \quad .295\end{array}$

8. GINV/G.N.P. $\begin{array}{llll}.056 & .11 & .12 & .191\end{array}$

9. PINV/G.N.P. $\begin{array}{llll}.094 & .11 & .12 & .165\end{array}$

SOURCE: Plan and Budget Organization, Economic Trends of Iran, 5th Edition, March 1978 . 

SECPORAL DISTRIBUTION OF 'IO'PAI IAABOR FORCE
(ThOuSandS) $1959-76$

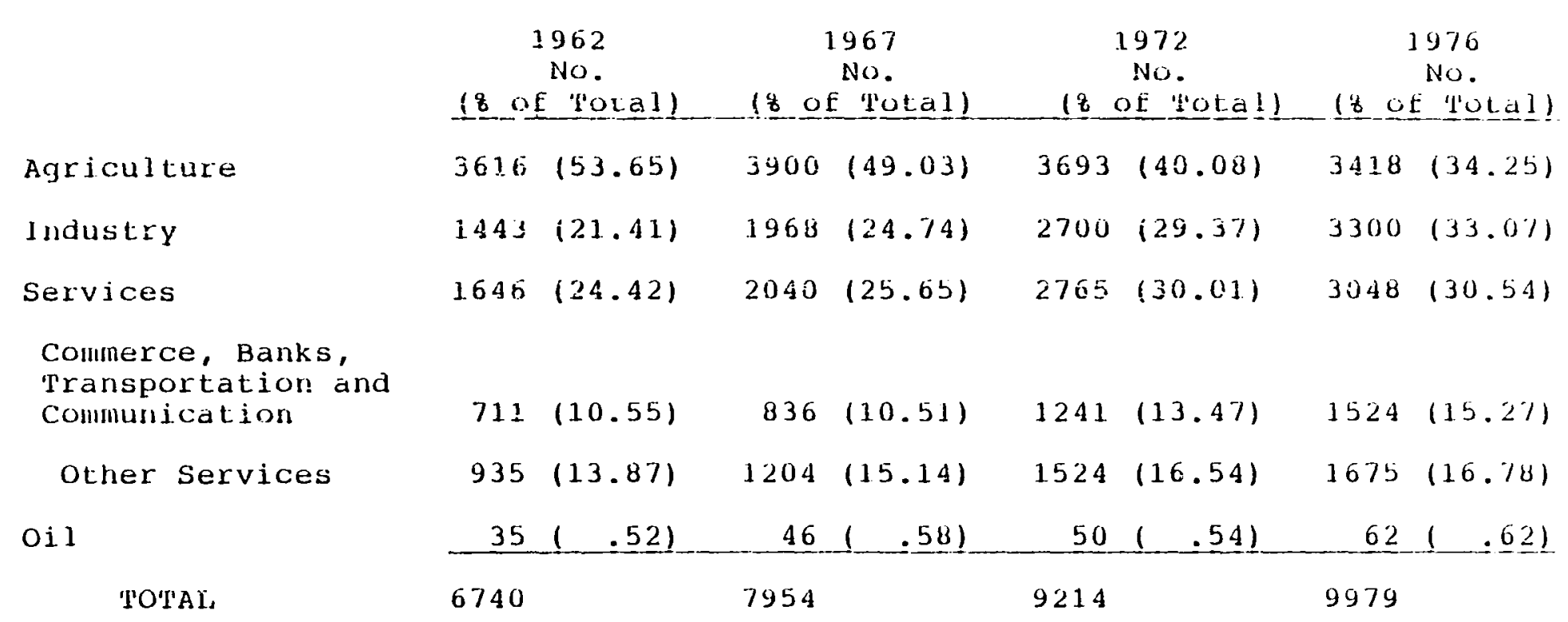

Source: Plan and Budget Organizalion, Economic Irends of Iran, 5th Eaition, March 1978. 
OU2PU' PER WORKER IH MAIH LCONOMIC SECIOLS

(Millions of Rials. 1959 Constanl pices/dhousands of Workers)

\begin{tabular}{|c|c|c|c|c|c|c|}
\hline & $\begin{array}{l}\text { vul put } \\
\text { Pc:: Worker }\end{array}$ & $\begin{array}{l}3962 \\
\text { Melat d ve Oul pat } \\
\text { per_Worke }\end{array}$ & $\begin{array}{c}\text { Out put } \\
\text { por Woyker }\end{array}$ & $\begin{array}{l}1972 \\
\text { kel at I ve Guiput } \\
\text { Per Wolker }\end{array}$ & $\begin{array}{c}\text { output } \\
\text { per Worker }\end{array}$ & $\begin{array}{l}1976 \\
\text { Relative ouldn } \\
\text { Pel Workes }\end{array}$ \\
\hline Agricultuas & 24.54 & .62 & 35.61 & .48 & 48.82 & .4 \\
\hline Indusiry & 40 & 1 & 71.26 & .95 & 112.39 & .92 \\
\hline Services & 72.84 & 1.83 & 130.38 & 1.74 & 2.19 .12 & 1.8 \\
\hline Hun-0:1 Urban & 57.49 & 1.45 & 101.14 & 1.36 & 163.63 & 1.34 \\
\hline Total Non-Oil & 39.72 & 1 & 74.73 & 1 & 121.57 & 1 \\
\hline
\end{tabular}

Source: plan and sudget organization, Econumle preng 


\begin{abstract}
APPENDIX B
BASIC TIME SERIES DATA OF THE IRANIAN ECONOMY
\end{abstract}

All variables are for annual time periods, in billion

of rials and thousand of persons. All variables are in terms of constant 1959 prices. 


\begin{tabular}{|c|c|c|c|c|c|c|}
\hline ous & VAA & VAU & VAO & 뇨 & CU & $\underline{C Q}$ \\
\hline 1959 & 85.40000 & 153.1000 & 33.00000 & 104.4000 & 109.1000 & 30.30000 \\
\hline 1960 & 87.00000 & 162.3000 & 36.90000 & 105.7000 & 117.8000 & 32.10000 \\
\hline$\$ 361$ & 87.80000 & 167.0000 & 44.60000 & 108.6000 & 122.0000 & 31.20000 \\
\hline 1962 & 38.70000 & 177.6000 & 50.10000 & 112.4000 & 131.5000 & 31.90000 \\
\hline 1363 & 90.10000 & 131.7000 & 53.50000 & 111.7000 & 135.9600 & 34.50000 \\
\hline 1964 & 92.10000 & 210.0000 & $5 e .80000$ & 122.2000 & 147.7000 & 41.00000 \\
\hline 1965 & 92.40000 & 240.3000 & 76.40000 & 130.6000 & 155.2000 & 54.50000 \\
\hline 1966 & 102.8000 & 264.1000 & 79.80000 & 132.8000 & 186.6000 & 61.70000 \\
\hline 1467 & 111.0000 & 295.8000 & 90.30000 & 141.9000 & 199.4000 & 70.10000 \\
\hline 1968 & 119.5000 & 331.3000 & 104.7000 & 143.3000 & 239.9000 & 81.90000 \\
\hline 1969 & 123.2000 & 367.1000 & 125.8000 & 138.1000 & 281.7000 & 96.40000 \\
\hline 1970 & 129.0000 & 412.1000 & 144.9000 & 142.4000 & 321.4000 & $111: 3000$ \\
\hline 1971 & 125.9000 & 467.9000 & 160.0000 & 140.7000 & 323.7000 & 142.7000 \\
\hline 1972 & 131.4000 & 553.4000 & 102.7000 & 131.8000 & 360.0000 & 187.7000 \\
\hline 1973 & 136.7000 & 658.6000 & 198.7000 & 150.3000 & 434.8000 & 220.7000 \\
\hline 1974 & 146.7000 & 773.3000 & 197.5000 & 167.5000 & $40 \% .0000$ & 323.8000 \\
\hline 1975 & $156: 4000$ & 904.7000 & 173.2000 & 172.5000 & 574.5000 & 372.4000 \\
\hline $1976^{\circ}$ & 366.9000 & 1030.800 & 197.3000 & 1 1.4000 & 641.0000 & 401.8000 \\
\hline
\end{tabular}




\begin{tabular}{|c|c|c|c|c|c|c|}
\hline obss & ItUVA & INvij & ExxO. & Extio & $I M C$ & $1 M K$ \\
\hline 1959 & 1.800000 & 50.30000 & 30.80000 & 10.70000 & 13.40000 & 34.80000 \\
\hline 1960 & 2.890000 & 52.80000 & 34.70000 & 9.80000 & 13.20000 & 36.00000 \\
\hline $196 i$ & 2.000000 & 51.10000 & 39.00000 & 10.50000 & 11.30000 & 35.60000 \\
\hline $196 \ddot{2}$ & 2.500000 & 46.190000 & 44.80000 & 9.00000 & 8.800000 & 34.90000 \\
\hline 1963 & 2.000000 & 52.10000 & 49.50000 & 10.30000 & 9.000000 & 31.90060 \\
\hline 1964 & 5.400000 & 56.40000 & 55.90000 & 11.10000 & 12,40000 & $\$ 5.00000$ \\
\hline 1965 & 5.500000 & 68.00000 & 54.60000 & 13.40000 & 12.80000 & 53.30000 \\
\hline 1966 & 5.300000 & 73.30000 & 73.90000 & 12.30000 & 13.40000 & 61.40000 \\
\hline 1967 & 7.000000 & 91.50000 & 86.00000 & 13.80000 & 16.50000 & 76.90000 \\
\hline 1968 & 1.800000 & 101.4000 & 90.00000 & 16.60000 & 19.80000 & 92.20000 \\
\hline 1969 & 8.600000 & 106.6000 & 116.7000 & 17.10000 & 23.40000 & 102.00000 \\
\hline 1970 & 8.700000 & 117.1000 & 131.5000 & 19.30000 & 28.80000 & 106.1000 \\
\hline 1971 & 11.90000 & 145.2000 & 153.1000 & 19.30000 & 42.20000 & 119.1000 \\
\hline 1972 & 18.60000 & 173.3000 & 176.4000 & 26.20000 & 52.30000 & 135.0000 \\
\hline 1973 & 18.80000 & 200.1000 & 196.8000 & 25.50000 & 75.20000 & 163.2000 \\
\hline 1974 & 22.60000 & 240.4000 & 193.4000 & 28.80000 & 120.8000 & 206.0000 \\
\hline 1975 & 33.90000 & 372.6000 & $1 \% .8000$ & 30.40000 & 170.3000 & 329.7000 \\
\hline $1976^{\circ}$ & 26.10000 & 429.0000 & 193.2000 & 33.80000 & 167.2000 & 361.2000 \\
\hline
\end{tabular}




\begin{tabular}{|c|c|c|c|c|c|c|}
\hline obs. & I.A & $\mathrm{I}, \mathrm{U}$ & LAND & POPR & popy & $\underline{N I} \underline{1}$ \\
\hline $195 y$ & 3582.000 & 3079.000 & 5095.000 & 14882.00 & 7309.000 & 18.20000 \\
\hline 1960 & 3586.000 & 3072.000 & 6023.000 & 14747.00 & 7483.000 & 19.40000 \\
\hline 1961 & 3600.000 & 3048.000 & 6153.000 & 14678.00 & 7694.000 & 19.00000 \\
\hline 1962 & 3616.000 & 3089.000 & 6094.000 & 14721.00 & 7968.000 & 19.30000 \\
\hline $196 . i$ & 3700.000 & 3178.000 & 6140.000 & 15001.00 & 8584.000 & 19.60000 \\
\hline 1954 & 3795.000 & 3272.000 & 5867.000 & 15294.00 & 2820.000 & 22.20000 \\
\hline$: 96 ;$ & 3799.000 & 3472.000 & 6283.000 & 15592.00 & 9200.000 & 24.00000 \\
\hline 1966 & 3775.000 & 3736.000 & 6379.000 & 15979.00 & 9010.000 & 27.80000 \\
\hline 1967 & 3900.000 & 4008.000 & 6499.000 & 16406.00 & 10387.00 & 30.60000 \\
\hline 1960 & 3850.000 & 4241.000 & 7060.000 & 16685.00 & 10903.00 & 33.60000 \\
\hline 1969 & 3830.000 & 4504.000 & 6990.000 & 16975.00 & 11423.00 & 35.90000 \\
\hline 1970 & 3769.000 & 4827.000 & 7616.000 & 17274.00 & 11982.00 & 39.00030 \\
\hline 1971 & 3719.000 & 5237.000 & 7624.000 & 17506.00 & 12514.00 & 42.80000 \\
\hline 1972 & 3693.000 & 5471.000 & 7615.000 & 17748.00 & 13072.00 & 39.60000 \\
\hline 1973 & $36 \% .000$ & 5735.000 & 7706.000 & 17392.00 & 13653.00 & 36.60000 \\
\hline 1974 & 3642.000 & 6047.000 & 7890.000 & 18239.00 & 14257.00 & $54.3000 \%$ \\
\hline 1975 & 3485.000 & 6162.000 & 8245.000 & 18489.00 & 14886.00 & 58.40000 \\
\hline 1976 & 3418.000 & 6499.000 & 7842.000 & $1787 \% .00$ & 15715.00 & 48.20000 \\
\hline
\end{tabular}

